\title{
Reservoir Characterization \& 3D Models of \\ Mt. Simon Gas Storage Fields in the Illinois Basin
}

\author{
Final Report
}

Reporting Period Start Date: October 1, 1999

Reporting Period Ending Date: June 1, 2003

Principal Author: David G. Morse

Co-author: Hannes E. Leetaru

Date Report Issued: September 22, 2003

DOE Award Number: DE-FG26-99FT40375

\author{
Principal Investigator: David G. Morse \\ Co-Investigator: Hannes E. Leetaru \\ Illinois State Geological Survey \\ 615 E. Peabody Dr. \\ Champaign, IL 61820
}

Submitting Organization:

The Board of Trustees of the University of Illinois

Grants \& Contracts Administration 109 Coble Hall

801 South Wright Street

Champaign, IL 61820-6242 


\title{
DISCLAIMER
}

This report was prepared as an account of work sponsored by an agency of the United States Government. Neither the United States Government nor any agency thereof, nor any of their employees, makes any warranty, expressed or implied, or assumes any legal liability or responsibility for the accuracy, completeness, or usefulness of any information, apparatus, product, or process disclosed, or represents that its use would not infringe privately owned rights. Reference herein to a specific commercial product, process, or service by trade name, trademark, manufacturer, or otherwise does not necessarily constitute or imply its endorsement, recommendation, or favoring by the United States Government or any agency thereof. The views and opinions of authors expressed herein do not necessarily state or reflect those of the United States Government, any agency thereof, or those of Kinder-Morgan, Inc. or Peoples Energy Corporation.

\begin{abstract}
In northern Illinois, the Cambrian Mt. Simon Sandstone is a permeable and porous formation that is used for natural gas storage by the utilities in the state. This study, sponsored by the U. S. Department of Energy, examined the Mt. Simon in the Manlove Gas Storage Field, Champaign County, Illinois, and the Herscher Gas Storage Field in Kankakee County, Illinois, in order to improve knowledge of the reservoir's character and geometry. The top of the reservoir sandstone occurs at $1190 \mathrm{~m}(3,900 \mathrm{ft})$ in

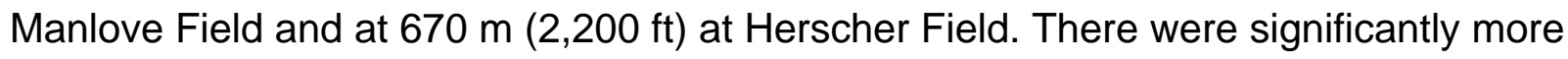


data available for the reservoir characterization study at Manlove Field than for Herscher Field. The 3-D porosity model of Manlove Field was well constrained by porosity and permeability measurements from 35 cores and calculated porosity values from modern FDC-CNL logs run in half of the 170 wells in the field. The resulting 3-D model indicated a heterogeneous reservoir with channel-confined, vertically discontinuous, high-porosity compartments.

Modeling of Herscher Field was less constrained, but still provided insight into reservoir compartments. Only six wells had reservoir core data and two wells had FDC-CNL logs at Herscher Field, while the remaining wells had only 1960s-era gamma ray-neutron logs, many of which were useless for neutron porosity determination due to the "gas effect". An alternative modeling approach was developed using a Vshale-porosity transform. This 3-D model indicated the presence of sand bodies with more lateral continuity than at Manlove Field, although vertical continuity remains fairly poor at both fields. Thus, although well-constrained models are preferable, models built with older, less-constrained data can provide improved understanding of the heterogeneous Mt. Simon reservoir's geometry and potential flow units.

Regional structure maps of the top of the Ordovician Galena Group (Trenton), the St. Peter Sandstone and the Mt. Simon Sandstone delineate present and prospective locations for Mt. Simon gas storage reservoirs. A new regional salinity map of the Mt. Simon waters shows the transition from potable water in northern and northwestern Illinois to a brine-filled formation in the deeper parts of the Illinois Basin. 


\section{TABLE OF CONTENTS}

$\begin{array}{ll}\text { Disclaimer } & 2\end{array}$

$\begin{array}{ll}\text { Abstract } & 2\end{array}$

Table of Contents $\quad 4$

$\begin{array}{ll}\text { List of Graphical Materials } & 6\end{array}$

$\begin{array}{ll}\text { Introduction } & 11\end{array}$

$\begin{array}{ll}\text { Executive Summary } & 12\end{array}$

$\begin{array}{ll}\text { Experimental Methods } & 14\end{array}$

$\begin{array}{ll}\text { Results and Discussion } & 16\end{array}$

Background on Mt. Simon Sandstone Geology 16

$\begin{array}{ll}\text { Regional Geology } & 20\end{array}$

$\begin{array}{ll}\text { Depositional Environment } & 20\end{array}$

$\begin{array}{ll}\text { Regional Structure } & 21\end{array}$

$\begin{array}{ll}\text { Salinity } & 22\end{array}$

Generalized Porosity vs. Depth Relations 22

Manlove Gas Storage Field 23

$\begin{array}{ll}\text { Introduction } & 23\end{array}$

$\begin{array}{ll}\text { Structure } & 25\end{array}$

$\begin{array}{ll}\text { Depositional Systems } & 26\end{array}$

$\begin{array}{ll}\text { Cross-bedded Sandstone (SSX) } & 27\end{array}$

Bioturbated Sandstone (SSB) $\quad 28$

Deformed Sandstone (SSD) 28 
Interstratified Sandstone and Shale (SS-SH) 28

$\begin{array}{lr}\text { Laminated Shale } & 29\end{array}$

$\begin{array}{ll}\text { Facies Inter-relations } & 30\end{array}$

Depositional Environments of Sediments $\quad 30$

$\begin{array}{ll}\text { Petrography } & 32\end{array}$

$\begin{array}{ll}\text { Petrophysics } & 33\end{array}$

3-D Porosity Model 36

Herscher Gas Storage Field 38

$\begin{array}{ll}\text { Introduction } & 38\end{array}$

$\begin{array}{ll}\text { Stratigraphy } & 39\end{array}$

History of the Field $\quad 40$

$\begin{array}{ll}\text { Petrology } & 44\end{array}$

$\begin{array}{ll}\text { Petrophysics } & 45\end{array}$

$\begin{array}{ll}\text { Reservoir Characterization } & 48\end{array}$

$\begin{array}{ll}\text { Conclusions } & 51\end{array}$

$\begin{array}{ll}\text { Regional Studies } & 51\end{array}$

$\begin{array}{ll}\text { Manlove Field } & 52\end{array}$

Herscher and Herscher NW Fields $\quad 52$

Application to Other Fields 53

$\begin{array}{lr}\text { Acknowledgements } & 54\end{array}$

$\begin{array}{ll}\text { References } & 55\end{array}$

$\begin{array}{ll}\text { List of Acronyms and Abbreviations } & 61\end{array}$

$\begin{array}{ll}\text { Figure Captions } & 61\end{array}$ 
$\begin{array}{ll}\text { Appendices } & 73\end{array}$

Appendix 1. Modal Analyses of Manlove Field, J. Williams \#4 73

Appendix 2a. Core Description, Peoples Energy, J. Williams \#4 Well 75

Appendix 2b. Graphic Description, Peoples Energy, J. Williams \#4 Well 81

Appendix 3a. Core Description, Peoples Energy, Hazen \#5 Well 85

Appendix 3b. Graphic Description, Peoples Energy, Hazen \#5 Well 91

Appendix 4. Northern Illinois Upper Mt. Simon Sandstone Water

$\begin{array}{ll}\text { Salinity Data } & 95\end{array}$

\section{LIST OF GRAPHIC MATERIALS}

Figure 1 Stratigraphic Column of Ordovician Through Precambrian rocks in Northern Illinois.

Figure 2 Cambrian Correlation Chart

Figure 3 Regional Structure Map- Top of Galena Group

Figure 4 Regional Structure Map- Top of St. Peter Sandstone

Figure 5 Regional Structure Map- Top of Mt. Simon Sandstone 
Figure $6 \quad$ Isopach map of Galena Group to St. Peter Sandstone

Figure 7 Regional Mt. Simon Sandstone Salinity Map

Figure 8 Regional Variation of Mt. Simon Porosity with Depth

Figure 9 Top of Mt. Simon Sandstone Structure Map, Manlove Field

Figure 10 Manlove Field Type Log

Figure 11 East-West Stratigraphic Log Cross-section Manlove Field

Figure 12 Top of Galena Limestone Structure Map, Manlove Field

Figure 13 3D View of Mt. Simon Well Control, Manlove Field

Figure 14 Core photograph of Cross-bedded Sandstone Facies

Figure 15 Core photograph of Bioturbated Sandstone Facies

Figure 16 Core photograph of Deformed Sandstone Facies

Figure 17 Core photograph of Interstratified Fine Sandstone and Shale Facies 
Figure 18 Core photograph of Laminated Shale Facies

Figure 19 Geophysical log of J. Williams \#4 Well

Figure 20 North-South Stratigraphic Log Cross-section, Manlove Field

Figure 21 Depositional Model Block Diagram for Manlove Field Area

Figure 22 Thin Section of Mt. Simon Medium-Coarse-Grained Sandstone

Figure 23 Thin Section of Mt. Simon Fine-Grained Sandstone

Figure 24 SEM Image of Reservoir Sandstone

Figure 25 SEM Image of Diagenetic Clay Minerals in Reservoir Sandstone

Figure 26 Core and Calculated Log-Derived Porosity Histograms

Figure 27 Three Dimensional Fence Diagram of Porosity Model for Manlove Field

Figure 28 East-West Cross-section of Porosity at Manlove Field 
Figure 29 North-South Cross-section of Porosity at Manlove Field

Figure 30 Horizontal Slice Map of Manlove Field Porosity Model- 4000'

Figure 31 Horizontal Slice Map of Manlove Field Porosity Model- 4034'

Figure 32 Horizontal Slice Map of Manlove Field Porosity Model- 4056'

Figure 33 Horizontal Slice Map of Manlove Field Porosity Model- 4132'

Figure 34 Horizontal Slice Map of Manlove Field Porosity Model- 4187'

Figure 35 Base Map of Herscher and Herscher NW Fields

Figure 36 Type log for the Herscher Field

Figure 37 Regional structural features in the Illinois Basin showing the location of Hersher and Herscher NW gas storage fields

Figure 38 Structure on top of the Galena Limestone at Herscher and Herscher NW Fields. 
Figure 39 Isopach of the interval between the top of Galena and the Eau Claire correlation point

Figure 40 Structure on top of the Mt. Simon Sandstone at Herscher and Herscher NW Fields

Figure 41 3-D view of Herscher and Herscher NW

Figure 42 Cumulative distribution of core permeability from the Mt. Simon Sandstone at Herscher Field.

Figure 43 Cumulative distribution of core porosity from the Mt. Simon Sandstone at Herscher Field.

Figure 44 Histogram showing the distribution of porosity using three different porosity calculations.

Figure 45 a) Wireline curves of Vshale and porosity, Knittel No 4 well. b) Cross plot of the Vshale and the neutron porosity.

Figure $46 \quad$ a.) Wireline curves of Vshale and porosity calculated, Armstrong No. 1 well b.) Cross plot of the Vshale and the neutron porosity. 
Figure 47 Stratigraphic cross section A-A' through the Herscher NW

Figure 48 Stratigraphic cross section B-B' through the Herscher anticline

Figure 49 Stratigraphic cross section C-C' through both Herscher and Herscher NW anticlines

Figure 50 Elmhurst sandstone isolith

Figure $513 D$ visualization of the porosity distribution at Herscher Field

Figure 52 Stratigraphic slices showing porosity distribution at the Herscher area.

\section{INTRODUCTION}

The Illinois State Geological Survey (ISGS), a division of the Illinois Department of Natural Resources and an affiliated agency of the University of Illinois, studied the Cambrian Mt. Simon Sandstone and the gas storage reservoirs that occur in this formation in the northern half of Illinois. For this study regional structure maps and porosity-depth charts were prepared to identify potential new natural gas storage areas. Published regional data on total dissolved solids (TDS) content of water in the upper Mt. Simon was compiled and mapped to characterize the variation in formation water chemistry. Detailed 3-D models of porosity at two gas storage fields, Manlove and Herscher, were prepared to illustrate the character of the reservoir. These studies will 
improve the geological understanding of reservoir gas injection and production and can later be used to prepare reservoir fluid flow simulation studies for optimal field management.

\section{EXECUTIVE SUMMARY}

Digital data have been compiled and organized to characterize the Mt. Simon Sandstone gas storage reservoirs in two fields in Illinois, the Manlove Field in Champaign County and the Herscher Field in Kankakee County, in order to improve the understanding of gas injection and production. This characterization can be used at a later time to prepare reservoir fluid flow simulations useful for optimal management of the gas storage fields. Regional structure maps of the top of the Galena (Trenton) Group, the St. Peter Sandstone and the Mt. Simon Sandstone reveal present day gas storage fields and point to possible locations for new fields. A new regional salinity map of the Mt. Simon waters shows the transition from potable water in northern and northwestern Illinois to a brine-filled formation in the deeper parts of the Illinois Basin.

Manlove Field, a 153 BCF aquifer gas storage field in Champaign County, Illinois operated by Peoples Energy Corp., is defined by a closed anticline in the Cambrian Mt. Simon Sandstone, a quartz sandstone aquifer about $1190 \mathrm{~m}$ (3900 ft) underground with a sealing caprock formed by the overlying Cambrian Eau Claire Formation. The field, located about 209 km (130 miles) south of Chicago, began operation in 1966. 
Maximum daily withdrawal is nearly $1 \mathrm{BCF}$. Gas is transported to the Chicago market via two large-diameter, company-owned pipelines.

Digital well log and core data for the Manlove field were compiled using Landmark Openworks software. Logs from over 300 wells and core analyses from 35 wells provided the framework for this study. Formation and internal Mt. Simon correlations, cross sections, structure and isopach maps were prepared. Cores from the J. Williams \#4 and the Hazen \#5 wells were described and analyzed in order to determine the depositional environment, lithologic facies, and mineralogy, and their relationship to porosity. Porosity values calculated from neutron, density, and more modern FDC-CNL logs were calibrated to core porosities. About $15 \%$ of porosity logs, primarily the older neutron logs, were omitted from 3-D modeling because of erroneous values generated by the "neutron gas effect". Cross-sections and interval slice maps were prepared to visualize the heterogeneity of the reservoir. The resulting 3-D model indicates a heterogeneous reservoir with channel-confined, vertically discontinuous, high-porosity compartments.

Herscher Field in Kankakee County was originally an oil field in the Ordovician Galena (Trenton) Group that was abandoned in the early 1900's. In 1952, the storage of natural gas for peak delivery to the Chicago market was begun in the Cambrian-age Galesville Sandstone. In 1956, storage of natural gas was begun in the underlying Cambrian-age Mt. Simon Sandstone and Elmhurst Sandstone member of the Eau Claire Formation, which proved to be a better-sealed reservoir than the Galesville Sandstone. 
Geologic characterization of the Mt. Simon/Elmhurst reservoir at Herscher has been completed using an unconventional technique because of the lack of modern wireline logs. An alternative empirical method using Vshale to estimate porosity was developed to create models in gas affected intervals. Although this technique does not fully capture the porosity variation seen in core for the cleanest sandstone, it provided the most reasonable method to model this reservoir. Results of this model of the Mt. Simon/Elmhurst reservoir reveal shale interval baffles and lateral porosity variations within the Herscher and Herscher Northwest fields, but there are no laterally extensive shales that would vertically compartmentalize the reservoir. Methodologies used in this project can be applied to other natural gas storage reservoir characterization projects where data quality is an issue and also to potential use of these formations for carbon sequestration.

\section{EXPERIMENTAL METHODS}

Regional structure mapping of the top of the Ordovician Galena Group (Trenton), the top of the St. Peter Sandstone, and the Mt. Simon Sandstone in northern Illinois was compiled from Illinois State Geological Survey well record files. Information from more than 9,100 wells was entered into a spreadsheet and used for this mapping. A conformable mapping technique, described later, was used to project the structure defined from the abundant shallow wells to deeper horizons that have only limited formation penetrations. Chemical analysis data (tds) for the Mt. Simon covering the northern half of Illinois were very limited and were assembled from literature, gas 
storage field operator and ISGS analytical chemistry databases and used to compile a map that showed the lateral distribution the salinity in this aquifer.

At Manlove, digital log and core analysis data from approximately 330 wells were acquired directly from the operating company; 175 of these wells reached the Mt. Simon Sandstone. Once the well logs were loaded on our workstation, the major formation boundaries and internal correlation markers were picked primarily using the Vshale log, which is based on the gamma ray trace. Porosity was calculated conventionally from neutron and density logs and calibrated against core data. Wells with only gamma rayneutron logs that had gas-affected values were not used in the modeling.

Two cores that passed through the entire gas storage interval at Manlove Field were described in detail and the sedimentary environments interpreted. Samples from the different facies in these cores were thin-sectioned and examined with a Scanning Electron Microscope (SEM) as well as with standard transmitted polarized light petrography. The thin sections from these cores were point-counted at 300 points per slide to determine mineralogical variations in the Mt. Simon Sandstone.

Three dimensional models of porosity were prepared for the Manlove and Herscher gas storage fields with a suite of Landmark Graphics Corporation software consisting of Openworks ${ }^{\mathrm{TM}}, \mathrm{ZMAP}^{\mathrm{TM}}$, Petroworks ${ }^{\mathrm{TM}}$ and Stratamodel ${ }^{\mathrm{TM}}$. 
Wireline logs in 31 wells in Herscher NW Field and 72 wells in Herscher Field that penetrate into the Mt. Simon were digitized and used in the reservoir characterization. Although there were no whole cores available for description and petrographic sampling, seven wells had commercial core descriptions and conventional porosity and permeability data that were used for calibration. Porosity was calculated from a Vshaleporosity transform developed for Herscher using off-structure GR-Neutron logs that did not show "gas effect" and was calibrated to the core data. All of the wireline log normalization, contouring, and volume modeling were performed with the above Landmark Graphics software.

\section{RESULTS AND DISCUSSION}

\section{BACKGROUND ON MT. SIMON SANDSTONE GEOLOGY}

The Mt. Simon Sandstone (Fig.1) is Upper Cambrian in age and lies unconformably on the Precambrian basement rocks of Illinois which are composed of granite or granodiorite in the north (Atekwana, 1996) and granite or rhyolite in the south (Bradbury and Atherton, 1965). In all of Illinois, only about 20 wells have penetrated through the entire Mt. Simon Sandstone interval to the Precambrian basement. Much of the Precambrian basement formed between 1.48 and 1.38 billion years ago and is part of the eastern granite-rhyolite province (Bickford et al. 1996). In east-central Illinois the

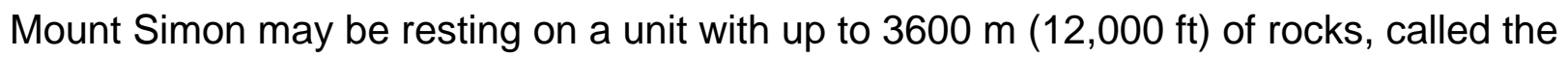
Centralia Sequence. In seismic lines these sub-Mt Simon rocks display "well-defined 
stratiform reflectivity" in east-central Illinois. The upper part of the Centralia, called the Enterprise Sequence, has sedimentary characteristics such as prominent dipping and truncated reflector clinoforms suggestive of a prograding shelf-margin-type sedimentary succession (McBride et al., 2003). The contact between the basement igneous rocks and the overlying Mt. Simon Sandstone is a major unconformity of unknown duration, perhaps as long as 500 million years (Willman et al. 1975).

The Mt. Simon Sandstone was named by Ulrich (in Walcott, 1914, p. 354) for outcrops of Mt. Simon near Eau Claire, Wisconsin. In general, the Mt. Simon is present throughout Illinois, ranging in thickness from less than $150 \mathrm{~m}$ (500 ft) in southwestern Illinois to over $780 \mathrm{~m} \mathrm{(2600} \mathrm{ft),} \mathrm{with} \mathrm{the} \mathrm{greatest} \mathrm{thickness} \mathrm{in} \mathrm{Illinois} \mathrm{in} \mathrm{the} \mathrm{east-central}$ part of the state (Buschbach, 1964 and1975, and McBride et al. 2003). In some areas of west-central Illinois, such as in Pike County (see Nelson, 1995), and in several wells in southwest Illinois, the Mt. Simon is very thin or absent. Presumably, this reflects nondeposition over Precambrian topographic highs with up to $240 \mathrm{~m}(800 \mathrm{ft})$ of relief in a distance of less than $12.7 \mathrm{~km}$ (eight miles), at the time when the regional blanket of Mt. Simon was being deposited elsewhere (Workman and Bell, 1948, p.2043; Atherton, 1971, p.31).

The Mt. Simon is overlain conformably by the Cambrian Eau Claire Formation, a unit composed of fine to medium-grained, dolomitic sandstone, siltstone and shale that may contain fossils of inarticulate brachiopods and dismembered trilobites (Twenhofel and others, 1935, p.1695). The base of the Eau Claire is characterized by gray sandstone 
with some "sooty" quartz grains that are coated with a fine black powder that consists of disseminated pyrite (Workman and Bell, 1948). This basal sandstone is called the "Elmhurst Sandstone Member" by Buschbach, 1964, p.32), and is sufficiently porous at Herscher Northwest gas storage field to be used as a reservoir. Shales above the Elmhurst provide seals for the many Mt. Simon gas storage fields in Illinois. The Mt. Simon differs from the Elmhurst in that the Mt. Simon is coarser-grained, may include quartz granules, generally lacks "sooty" grains, exhibits a marked decrease in the amount of siltstone and shale, and lacks fossils, glauconite, dolomite and calcite (Bell and others, 1964, p.26)

The Mt. Simon does not outcrop in Illinois, but correlative units are exposed in southern Wisconsin, southeast Minnesota, and in Missouri (Fig. 2). The Mount Simon is known in the subsurface throughout Indiana, lowa, Michigan and western Kentucky. Equivalent Cambrian sandstones are present as far east as Ohio. To the southwest the Mt. Simon has been correlated with the Lamotte Sandstone of Missouri (Workman and Bell, 1948, p. 2043; Houseknecht and Ethridge, 1978). It may include equivalents in the Bayfield Sandstone of northern Wisconsin, the Jacobsonville Sandstone of northern Michigan and the Fond du Lac Sandstone of Minnesota (Buschbach, 1964). The Mt. Simon comprises the lower part of the Sauk Sequence of Sloss (1963). The regional relations of the lower Sauk were summarized by Sargent (1991). The Mt. Simon is the basal sandstone of the Potsdam Sandstone Megagroup of Swann and Willman (1961) and Willman et al.,1975). 
The Mt. Simon consists primarily of medium to coarse quartzose sandstone with local granule-rich sandstone beds. Thin beds of red, green or gray micaceous shale are sparsely interbedded with the sandstone, especially toward the top of the Mt. Simon. Also interbedded are thin beds of fine to medium feldspathic sandstone. Sorting of the Mt. Simon varies from fair to very good. Typically, the coarse-grained beds are better sorted and have higher porosity than the fine-grained sandstone beds.

Although the Mt. Simon in northern Illinois has been divided into seven members based on alternation of relatively coarse sand and granule-rich intervals with relatively finegrained intervals (Templeton, 1950), these have not been traced to northeastern Illinois where Buschbach (1964) has only recognized the upper three members - from the base upward these three consist of the Lacey, Gunn and Charter Members (Fig. 1). Gas storage is typically in the upper $65 \mathrm{~m}$ (200 feet) of the formation, presumably in the Charter Member, although no attempt to recognize the members was made in this study.

The Mt. Simon, where it occurs at depths of less than approximately $1500 \mathrm{~m}$ (5000 ft) deep, is a porous sandstone. It is overlain nearly everywhere by a thick, impervious shale, the Eau Claire Formation. On anticlinal structures, this combination creates potential storage reservoirs for natural gas that have been recognized and utilized by most of the utilities for gas storage in Illinois. Twelve Mt. Simon gas storage fields were developed in Illinois in the 1950s and 1960s; two of these, the Manlove and the Herscher Fields, were examined in detail for this study. The Mt. Simon fields are called, 
"aquifer gas storage reservoirs" because the Mt. Simon was generally water-bearing prior to the injection of natural gas that was brought to the site by pipeline. Once injected, part of the gas volume, called, "working gas," is withdrawn and delivered to market to meet peak use requirements. Gas remaining in the reservoir provides pressure and is called, "cushion gas" or "base gas". Storage typically occurs in only the upper $30 \mathrm{~m}$ to $60 \mathrm{~m}$ (100 ft to $200 \mathrm{ft}$ ) of the Mt. Simon, following the limits of structural closure at the reservoir.

\section{REGIONAL GEOLOGY}

\section{Depositional Environment}

The Mt. Simon Sandstone is commonly interpreted as forming in shallow, sub-tidal marine environments (Droste and Shaver, 1983). Based on southern Wisconsin outcrop studies Driese and others (1981) interpreted it as a stacked, largely progradational, shoaling- and fining-upward tidal sequence that contains marine trace fossils in many intervals. In core from central Illinois Sargent and Lasemi (1993) have interpreted the fining -upward cycles in the upper part of the Mt. Simon as peritidal deposits. Cores from the upper part of the Mt. Simon Sandstone at Manlove Field, show sedimentary structures that support a similar tidal to shallow sub-tidal depositional environment for the rocks in east-central Illinois. See the lithofacies section below for a more detailed description and interpretation. In general, the paleogeography of Illinois at the time of uppermost Mt. Simon deposition was one of a low relief coastal setting in a subsiding basin that was open to the ocean to the south (Kolata, 1991, p. 197). 


\section{Regional Structure}

Data from all significant wells drilled in the northern half of Illinois were compiled to create regional structure contour maps of the tops of the Ordovician Galena (Trenton) Group (Fig. 3), the Ordovician St. Peter Sandstone (Fig. 4), and the Cambrian Mt. Simon Sandstone (Fig. 5). The region covered by the database comprises the prime potential area for developing new natural gas storage sites in Illinois that could reasonably provide gas to the Chicago market. A pallistering technique that adds isopachs to shallow structure maps was used to create deeper structure maps. Thus, the isopach from the top of a shallow, well-controlled marker bed, such as the Galena (Trenton), to the top of the next underlying interval, the St. Peter Sandstone (Fig. 6) , was added to the structure map of the top of the Galena (Fig. 3) to create a structure map of the St. Peter Sandstone. This process was then repeated from the St. Peter to the Mt. Simon to create the Mt. Simon structure map (Fig.5). This technique is also called, "conformable mapping".

Up to eight regional formation tops in all wells of northern Illinois have been compiled, but the number of deeper formation penetrations decreases sharply below the Galena (Trenton). The database containing these log tops comprises over 9,100 wells and is included with the digital version of this report. The formation tops data were reviewed for accuracy using contoured isopach and structure maps of the units. This quality check procedure permitted the identification and correction of wells where contour bulls eyes occurred. 
The existing gas storage fields are clearly identified by the closed contours that have abundant well spots. Additional areas of closure that may have potential for gas storage are delineated by the closed contours.

\section{Salinity}

Chemistry data for the Mt. Simon Sandstone formation water in the northern half of Illinois are sparse, especially in areas other than the natural gas storage fields that utilize the Mt. Simon Sandstone as a reservoir. The USGS drilled several test holes and analyzed water from several different aquifers in northeastern Illinois. A map of the variations in salinity (tds) of the upper Mt. Simon Sandstone formation water is shown in Fig. 7. The raw data for this map are found in Appendix 4. The Mt. Simon Sandstone formation water salinity increases from north or northwest to south or southeast and with depth. Total dissolved solids (tds) increase from $235 \mathrm{mg} / \mathrm{l}$ to as much as 100,000 $\mathrm{mg} / \mathrm{l}$ along this trend. The Mt. Simon is a potential aquifer for potable water in northern and northwestern Illinois, near its recharge area that lies to the north in Wisconsin where the formation outcrops. However, in the deeper parts of the Illinois Basin the water is a brine.

\section{Generalized Porosity vs. Depth Relations}

Core analysis data were compiled from reports and well data donated to the ISGS primarily by the gas storage operators. The core data came from 56 wells and included about 8400 values from tested samples that ranged in depth from $661 \mathrm{~m}(2168 \mathrm{ft})$ to 
1799m (5900ft). These data were supplemented with 610 porosity values calculated from geophysical log (density or density-neutron cross-plot) of deep, clean, Mt. Simon sandstone intervals that ranged in depth from $1372 \mathrm{~m}$ (4500ft) to $3505 \mathrm{~m}$ (11492ft) from five deep Illinois wells. A summary cross-plot of the porosity vs. depth was prepared by computing and plotting the mean porosity of each of the wells with core and log data, the mean porosity plus one standard deviation, and the mean plus two standard deviations. Logarithmic regression lines were drawn for each of these sets of data. Well summary data points and the respective regression curves are shown on Fig. 8.

We anticipate that typical reservoir intervals will have greater porosities than the mean computed from random core analysis points. The best reservoir sandstones will have porosity values close to two standard deviations above the mean, whereas the more typical reservoir rocks will have porosity values close to the mean plus one standard deviation. Thus, the Mt Simon Sandstone is likely to have a reservoir porosity of about $5 \%$ at $3660 \mathrm{~m}(12,000 \mathrm{ft}), 7 \%$ at $1830 \mathrm{~m}(6000 \mathrm{ft}), 13 \%$ at $1220 \mathrm{~m}(4000 \mathrm{ft})$, and $18 \%$ at $610 \mathrm{~m}(2000 \mathrm{ft})$.

\section{MANLOVE GAS STORAGE FIELD}

\section{Introduction}

Manlove Field, a 153 billion cubic feet (BCF) aquifer gas storage field, including cushion gas, is located in Champaign County, Illinois and is operated by Peoples Energy Corp. The field is formed by a north-south trending, closed anticline $11.3 \mathrm{~km}$ (7 miles) long and 9.7km (6 miles) wide with about 45m (150 ft) of structural closure in T21N and R7E. 
The reservoir is in the Cambrian Mt. Simon Sandstone, with a sealing caprock formed by about 31m (100 ft) of dense shale in the overlying Cambrian Eau Claire Formation. The field has a steep west flank and a gentle east flank (Fig. 9). The spill point lies in the northeast part of the field. The field covers approximately $73 \mathrm{~km}^{2}$ (28 square miles). The Mt. Simon is about $1220 \mathrm{~m}$ (4000 ft) deep in this field and has an average porosity of 12 percent and an average permeability of 100 millidarcies.

The field, located about 209km (130 miles) south of Chicago, began withdrawals in 1966. Maximum daily withdrawal capacity is approximately $1 \mathrm{BCF}$; maximum annual withdrawal (maximum working gas) is about 43 BCF (1994, Pipeline Report,. p.47). Gas is transported to the Chicago market via two large-diameter, company-owned pipelines.

The field was originally drilled as a St. Peter Sandstone gas storage field, but after initial injection in 1961, gas was discovered in the glacial drift above the field. Injection was halted in August of 1961. The source of the leak could not be determined. Gas was then injected into the underlying Galesville Sandstone in 1963, which also appeared to leak. Later tests of the even deeper Mt. Simon Sandstone indicated that the Eau Claire Formation provided a proper seal and that there was sufficient porosity and permeability in the reservoir to store and deliver gas effectively. Gas was initially injected into the Mt. Simon aquifer in 1964 and the project became operational in 1966. 
The Mt. Simon Sandstone at Manlove Field is not a homogeneous reservoir. Gamma ray logs indicate that many thin shaley interbeds separate sandstones in the Mt. Simon

(Fig. 10), but most of these shaley strata cannot be correlated widely (Fig. 11).

Examination of core from the J. Williams \#4 well in the field indicated that the shale beds that caused these spikes in the gamma-ray logs are very thin, ranging from a few millimeters to a few centimeters in thickness, but they had sufficient natural radioactivity to generate high gamma ray values. The Mt. Simon Sandstone consists of stacked clean sandstone units capped with thin interbeds of fine sandstone, siltstone and shale. These interbeds produce the indents observed in the Vshale log curves. Correlating these between neighboring wells just 200 m (660') apart was difficult, however, and they could not be used to finely subdivide the reservoir. The only good correlative marker within the Mt. Simon was the L120 located approximately $67 \mathrm{~m} \mathrm{(220} \mathrm{ft)} \mathrm{below} \mathrm{the} \mathrm{top} \mathrm{of}$ the Mt. Simon sandstone (Fig. 11).

\section{Structure}

In order to define the structure of the field with the greatest detail, shallower formation tops, such as the Galena Group (Fig. 10) were mapped in addition to those of the Mt. Simon Sandstone. The field had numerous shallow wells that had been used to define the configuration of the reservoir. Log tops from all the wells were compiled and structure maps for the top of the Galena Group (Ordovician) (Figure 12), and the top of the Mt. Simon Sandstone (Fig. 9) were prepared with the structure of the deeper maps conforming to the details of the shallower structure. This structure map of the top of the Mt. Simon and a 3-D diagram of the area Figure 13) illustrate the north-south oriented, 
asymmetrical, doubly plunging anticline. Gas is stored to an elevation of about $-994 m$ ($3260 \mathrm{ft}$ ) filling a vertical closure of approximately $45 \mathrm{~m}$ (150 ft). At this elevation, the area under closure is approximately $73 \mathrm{~km}^{2}$ (28 miles ${ }^{2}$ ) (Buschbach and Bond, 1974, p.51).

\section{Depositional Systems}

Five lithofacies were identified and described in cores from the Peoples Gas, \#4 J. Williams and \#5 Hazen wells. The detailed core descriptions of these cores are presented in Appendices 2 and 3 of this report. These cores are from the upper $76 \mathrm{~m}$ (250 ft) of the Mt. Simon Sandstone and encompass the intervals used for gas storage.

The type well, the J. Williams \#4, was drilled in July of 1992, late in the field's development. It was cored through the upper Mt. Simon and has modern FDC-CNL logs. The upper 23m (75 ft) of Mt. Simon Sandstone are not used for gas storage at Manlove. This interval is more shaley and contains sandstones that are thinner, finer grained and have lower porosity than the sandstones that lie below. The deeper strata that comprise the active Mt. Simon gas storage reservoir consist of thick-bedded, coarse-grained, cross-bedded sandstone beds separated by thin intervals consisting of impermeable beds with high gamma ray spikes composed of very fine sandstone, siltstone, and shale. 
The lithofacies seen in the two primary cores consist of the following: 1) cross-bedded sandstone, 2) bioturbated sandstone, 3) deformed sandstone, 4) interstratified fine sandstone and shale, and 5) laminated shale.

\section{Cross-bedded Sandstone (SSX)}

The cross-bedded sandstone (SSX) is primarily composed of moderately well-sorted, medium- to coarse-grained, cross-bedded sandstone strata, some of which may have very thin, poorly-sorted, granule conglomerate beds at their bases (Fig. 14). This facies comprises the main reservoir type in the Illinois gas storage fields. The sandstone is commonly porous and permeable. Cross-bedding consists primarily of thin troughshaped sets (5-30 cm high) and less abundant, thicker, tabular-shaped sets (50 to 100 $\mathrm{cm}$ high). Reactivation surfaces, rarely marked by a fine dark gray shale drape a few millimeters thick, occur locally. The rock is typically pale buff-colored, but at the top and the base of the J. Williams \#4 core, the sandstone has a pale reddish (hematitic) color. Quartz granules up to $4 \mathrm{~mm}$ in diameter may also occur within the sandstone along the bases of some of the trough sets; granules $2 \mathrm{~mm}$ in diameter may be scattered within the sandstone. Some of the trough strata may contain asymmetrical ripples within the cross-bed planes. Trough cross-bed sets are stacked forming co-sets up to four meters thick. These co-sets have sharp bases and are typically overlain by thin sequences of the finer-grained, bioturbated sandstone or by the interstratified sandstone and shale facies. The cross-bedded sandstone strata commonly have a "blocky" or "finingupward" gamma ray log motif. 


\section{Bioturbated Sandstone (SSB)}

The bioturbated sandstone (SSB) consists of fine to coarse, poorly to moderately wellsorted sandstone (Fig. 15). It includes strata with clusters of sand-filled, vertical burrows, each approximately 3 to $5 \mathrm{~mm}$ in diameter and up to $5 \mathrm{~cm}$ in length, as well as structureless or mottled sandstone beds. The burrow-filling may have a darker gray hue compared to the surrounding sandstone. The vertical, tube-like burrows are identified as Skolithos. The degree of burrowing ranges from slight to complete destruction of any sedimentary layering. Multiple beds of the bioturbated sandstone may stack up to $3 \mathrm{~m}$ thick. Faint bedding of the cross-bedded sandstone may be preserved between these burrows or between stacked beds of the bioturbated sandstone. This facies may or may not be porous depending on the original facies prior to bioturbation.

\section{Deformed Sandstone (SSD)}

The deformed sandstone (SSD) consists of medium to coarse sandstone with swirly, convoluted or discontinuous bedding (Fig. 16). It is relatively rare, occurring within thick co-sets of cross-bedded sandstone. The deformed intervals range from 30 to $130 \mathrm{~cm}$ thick and are bounded by normal, horizontal or cross-bedded strata. A dewatering or flame structure was observed within this facies.

\section{Interstratified Sandstone and Shale (SS-SH)}

The interstratified sandstone and shale (SS-SH), one of the fine-grained, non-reservoir facies seen in the Mt. Simon, consists of interstratified thin-beds and laminae of very fine to fine sandstone, and fine-grained siltstone or shale (Fig. 17). Rhythmic 
alternations of millimeter thick laminae of these lithologies occur in beds up to $30 \mathrm{~cm}$ in thickness. Shale laminae range from less than half a millimeter to a centimeter or two in thickness. Horizontal, tubular, very fine, sandstone-filled, Planolites burrows occur within many of the shaley laminae. The sandstone-shale laminae may be planar, wavy, lenticular or flaser-bedded. Mudcracks filled with fine-sandstone (Fig. 17B) were observed within these strata in both cores. Intervals of this facies commonly are interbedded with beds of the bioturbated sandstone or may be sharply overlain by beds of the cross-bedded sandstone. This fine-grained facies forms vertical and lateral barriers to gas flow in Manlove Field although other than at the L120 marker, intervals of the facies could not be readily correlated from well to well.

\section{Laminated Shale (SH)}

The laminated shale (SH) occurs as part of the L120 marker bed. Shale is the predominant lithology, although thin interlaminae of siltstone or shale with fine-sandfilled Planolites burrows can be seen. This non-reservoir facies (Fig. 18) is rarely more than $10 \mathrm{~cm}$ thick. It may grade into the interlaminated sandstone and shale (SS-SH) facies, but is recognized when the lithology is predominantly shale. The L120 marker, which consists of both the laminated shale $(\mathrm{SH})$ and the interstratified sandstone and shale (SS-SH) facies, contains the thickest layers of the laminated shale facies seen at Manlove, and can be correlated across the field. Elsewhere, thinner unnamed shale strata can be identified by their high value spikes on the gamma ray log, but these strata are discontinuous from well to well. 


\section{Facies Interrelations}

These Mt. Simon lithofacies are packaged into units 2 to 5 meters thick that can be identified on gamma ray logs (Fig. 19). They are composed predominantly of crossbedded sandstone capped by beds of bioturbated sandstone (SSB) and overlain by interlaminated sandstone and shale (SS-SH), thus forming a fining-upward package. These packages, or simply the interlaminated sandstone and shale beds (SS-SH), can rarely be recognized by their gamma ray log signatures further than one well location away (201 m or $660 \mathrm{ft}$ ) (Figs. 11 and 20). One shaley interval located below the gas storage zone, named the L120 marker, was correlated field-wide, a requirement for the 3D porosity modeling, but many of the correlation picks for this horizon were extended through sandstone intervals at the level where the shales occurred in adjacent wells.

\section{Depositional Environments of Sediments}

The Mt. Simon is commonly interpreted as having been laid down in a shallow, sub-tidal marine environment (Droste and Shaver, 1983). Based on their southern Wisconsin outcrop studies, Driese and others (1981) interpreted it as a stacked succession of largely progradational, shoaling- and fining-upward tidal deposits containing widespread marine trace fossils. In general, the paleogeography of Illinois at Mt. Simon time was one of a low relief, subsiding basin that was open to the ocean to the south (Kolata, 1991, p. 197)

The depositional environment for the upper part of the Mt. Simon Sandstone interpreted from the cores at Manlove Field, was probably a coastal setting comprising fine-grained 
tidal flat sediments, and cross-bedded, meandering tidal channel and tidal bar deposits (Fig. 21). Sand body geometries, described later, suggest there may have been barrier bars as well. The presence of Skolithos and Planolites burrows in these deposits indicates marine influence. The cross-bedded sandstone facies is interpreted as a shallow subtidal deposit formed by meandering tidal channels and subaqueous tidaldelta bars. Clay-drape laminae on some of the cross-bedded sandstone beds are characteristic of a tidal regime in which clay settles out of suspension during slack water periods of a tidal cycle or during neap tides of the lunar cycle. Clay intraclast lags indicate reworking of previously deposited thin shale beds and their transportation for short distances in laterally migrating channels. The bioturbated sandstone facies (SSB) with Skolithos burrows was formed in high-energy settings, such as tidal-delta bars or tidal channels, with coarse-grained substrates that are constantly being reworked by tidal currents and suspension-feeding infauna (Seilacher, 1967). The deformed sandstone (SSD) strata are interpreted as slump deposits that formed during the collapse of undercut banks of meandering tidal channels.

The finer-grained, laminated shale (SH) and the interbedded sandstone and shale facies (SS-SH) sediments probably were deposited on tidal sand and mud flats. Mud cracks indicate subaerial exposure. Locally, the interlaminated sandstone and shale beds have fine rhythmic spacing, an indicator of tidal deposition. Very fine sandstone is deposited by tidal currents and the mud is deposited from suspended sediment during slack tides. Planolites burrows are common, indicating a marine influence. The laminated shale (SH) may form in a subtidal lagoon or bay. 
Similar tidal sedimentary environments have been interpreted for the overlying Eau Claire Formation (Huber, 1975; Byers 1978). Thus, it appears that essentially the same sedimentation and depositional environments continued across the Mt. Simon-Eau Claire boundary, forming a conformable contact.

\section{Petrography}

The Mt. Simon Sandstone contains a wide range of grain sizes and minerals. The reservoir sandstones examined in the cores from the $\mathrm{J}$. Williams \#4 and Hazen \#5 wells consist of clean, well-sorted, medium to very coarse grains of quartz cemented by a quartz overgrowths (Fig. 22a \& b). Pores are large and smoothly lined by this cement (Fig. 23). Fine- to very fine-grained sandstones and less well-sorted sandstones (Fig. 22c) contain significantly more relatively unaltered K-feldspar grains than the coarser sandstones (see Table 1 below). K-feldspar in the Mt. Simon occurs only as fine to very fine grains. These grains have angular, euhedral outlines indicative of diagenetic feldspar overgrowths. No plagioclase feldspar was seen. Modal analyses of 31 thinsections from the $\mathrm{J}$ Williams \#4 well are listed in Appendix 1. SEM images of coarsegrained reservoir sands (Fig. 24) illustrate the euhedral quartz overgrowths and the open pore system. Diagenetic clay minerals are sparse and based on the SEM images, they appear to be mostly composed of illite (Fig. 25). 
Table 1. Feldspar Variation with Sandstone Grain-size

(based on thin-section point counts, J. Williams \#4 well, 300 points per thin section)

Grain Size

Coarse ss

Medium-coarse ss

Medium ss

Medium-fine ss

Fine ss w/ shale

interlaminae

\section{Average Feldspar}

\section{Content}

$2.35 \%$

$6.00 \%$

$7.23 \%$

$15.67 \%$

$21.33 \%$

\section{Petrophysics}

A major goal of this research project was to create an accurate porosity model of the Manlove Field gas storage reservoir that could be used both in volumetric analysis and in reservoir simulations. However this goal was constrained by the fact that many of the wells had a wireline log suite that included only a gamma ray and an older-style neutron log. The older neutron logs were commonly calibrated in counts per second and had to be converted into porosity units. 
Gamma ray logs cannot be directly compared with each other in the field because wellbore conditions and incorrect calibrations result in variable scales for the curves. In order to compare gamma ray logs from well to well, Vshale values were calculated, using the Clavier equation method (see below). This is a normalization technique that scales the gamma ray from $0 \%$ in pure sandstone to $100 \%$ in pure shale and the resulting values allow well-to-well comparison. The Clavier equation is recommended for use in older strata whereas the linear gamma ray Vshale equation is better in Tertiary-age strata (Clavier et al. 1977).

Neutron porosity was calculated for all of the wells using standard methods described for the older types of neutron logs (Dull 1991; Brown and Bowers 1957; Swulius 1986). In these calculations the shale porosity is assumed to be $30 \%$ and the average porosity in clean sandstone (small amounts of clay minerals) is estimated from core analyses to be $14 \%$. There is a logarithmic relationship between neutron measurements from the wireline tool and porosity. A shale correction to porosity was made with the Vshale values from the Clavier equation.

\author{
Vshale Linear \\ Vsh_linear $=(G R-G R \min ) /($ GRmax - GRmin $)$ \\ Vshale Clavier \\ VSHCLV = $1.7-$ SQRT $\left(3.38-(\text { Vsh_linear }+0.7)^{\wedge} 2\right)$ \\ Neutron porosity \\ phi_scaled30 $=10^{\wedge}((\mathrm{m} *$ NEUTRON $)+a)$
}


Slope $(m)$ and intercept (a) for each well

\section{Porosity Shale Correction}

$$
\text { PHIE }=\text { phi_scaled30 }-(\text { VSHCLV * .3) }
$$

Porosities, calculated by logging companies using standard cross-plot methods for most of the modern compensated density-neutron logs, correlated very well to detailed core analysis measurements. These log values were used as standards for further porosity analysis. Determining true log porosity and the amount of porosity that had to be attributed to "gas effect", and not to true porosity, were difficult and caused many of the neutron log porosities to be questioned. Core porosity values in some of these wells provided a basis for calibration, allowing retention of those values. Porosity values in 124 of the total 175 wells in the immediate field area were used to make the 3-D porosity model. These 124 wells included 43 wells with gamma ray-neutron logs that were drilled prior to gas injection, 35 cored wells that provided a means of calibrating the log porosity, particularly in old gamma ray-neutron logs, and finally 81 wells with modern FDC-CNL logs, several of which also had cores for porosity verification.

Typical histograms of cored porosity (shown in red) and density-neutron porosity (shown in green) are shown in Fig. 26. Mean core and density-neutron values agree well. Data from 35 cored wells were available for calibration of porosity. Wells with neutron logs that agree with core and uncored wells with neutron logs that showed no "gas effect" were used in the model. 


\section{3-D Porosity Model}

The porosity values calculated from wireline logs were used to generate a three dimensional model of the distribution of porosity throughout the Mt Simon reservoir at Manlove Field. The grid used to generate the model have $x$ and $y$ increments of $76 \mathrm{~m}$ (250 feet). The vertical interval is about $0.6 \mathrm{~m}$ ( 2 feet) but varies across the field because the model assumes a proportional thickening and thinning of grid cells in the interval between the top of Mt Simon and the L120 marker bed.

A 3D fence diagram view of this model is shown in Fig. 27. Porosity values have been lumped in $2.5 \%$ intervals for color contrast. Key model cross sections have been drawn through this model in a north-south and an east-west direction. These cross sections can be viewed in both a structural sense (Figs. 28a and 29a) or in a stratigraphic sense by hanging the section from a datum consisting of the top of the Mt. Simon Sandstone (Figs. 28b and 29b).

Horizontal slice maps of the porosity model were prepared to determine lateral geometry and continuity of sandstone and shale bodies. A vertical slice from the far northeast part of the model and a small plot of the gamma ray log for the J. Williams \#4 well are shown in their proper location for reference. These maps plot the average porosity of an approximately 65 to $100 \mathrm{~cm}$ ( 2 to $3 \mathrm{ft}$ ) thick grid interval proportionally spaced from the top of Mt. Simon Sandstone at $1211 \mathrm{~m}$ (3972 ft) to the correlated shale located about $65 \mathrm{~m}(215 \mathrm{ft})$ below the top of the Mt. Simon. Pertinent samples of these 
maps, shown in Figs. 30 through 35, corresponding to depths in the J. Williams \#4 well, reveal the geometry of reservoir sandstone compartments and shale seals.

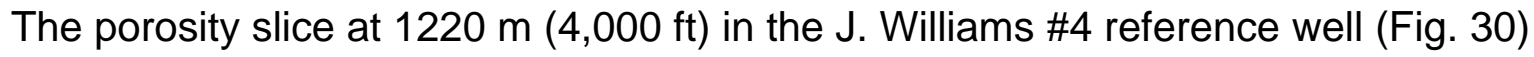
shows an east-west tidal channel. The core from the reference well indicates that this channel sandstone contains abundant Skolithos burrows, a few thin shale intraclasts and is medium- to coarse-grained. Lateral to the reference well, the facies have low porosity and are interpreted to be lagoonal or intertidal mud flats. This interval lies above the gas storage reservoir.

The porosity slice at $1230 \mathrm{~m}(4,034 \mathrm{ft})$ in the reference well (Fig. 31) shows a bifurcating, west to east-flowing, tidal channel system (high porosity) and surrounding tidal mud flats (low porosity). In the core of the reference well, the sandstone at this depth is coarse- to very coarse-grained, porous, and contains thin trough cross-bed sets and a few Skolithos burrows. The channel branches to the west of the reference well with a geometry that suggests flow from west to east. To the north and south of this well lie lower-porosity tidal flat facies deposits. The FDC-CNL log at J Williams \#4 indicates that the channel sand, shown here, lies just above a thin shale and above the main gas reservoir.

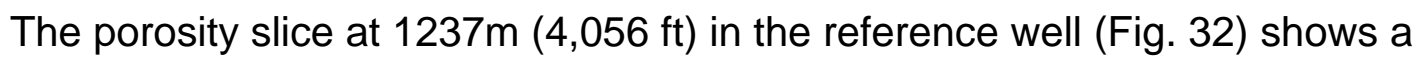
widespread, porous sandstone extending from the reference well. This occurs in the upper gas-storage interval. The sandstone is cross-bedded, coarse- to very coarse- 
grained and porous. More porous sands occur to the west of the reference well in a north- to south-oriented band (barrier island or tidal delta?) that is elongate perpendicular to two narrow tidal channels that are further west.

The porosity slice at $1260 \mathrm{~m}(4,132 \mathrm{ft})$ in the reference well (Fig. 33) shows another sinuous, high-porosity tidal channel sand oriented in an east to west direction. It is joined by a channel or remnant barrier sand from the north. To the east is possibly a

younger barrier sand. The core in this interval in the reference well is coarse- to very coarse-grained and cross-bedded.

The deepest porosity slice at $1277 \mathrm{~m}(4,187 \mathrm{ft})$ in the reference well (Fig. 34) shows the distribution of the L120 marker bed, the only high gamma ray shale that can be readily correlated across the field. Core from this interval shows interlaminated black and dark greenish black shale and fine to very fine-grained sandstone. Sand-filled Planolites burrows are abundant. Deposition was likely in a back-barrier, tidally influenced lagoon, a tidal mud flat or may have resulted from minor marine flooding event.

\section{HERSCHER GAS STORAGE FIELD}

\section{Introduction}

The Herscher and Herscher NW anticlines (Fig. 35), located in the southwest corner of Kankakee County, IL, were producing oil from the Galena (Trenton) in the early 1900's. The field was abandoned for more than 40 years until, in the late 1950s when it was 
converted into a natural gas storage facility for peak demand delivery in the Chicago metropolitan area. Most of this natural gas is stored in the Cambrian Mt. Simon Sandstone (Fig. 36), but additional storage occurs in the Cambrian Galesville Sandstone and Elmhurst Sandstone Member of the Eau Claire Formation (Benesh et al., 1956).

The goal of this project was to improve the efficiency of injecting and withdrawing natural gas from the Mt. Simon Sandstone by developing an improved reservoir characterization model of the reservoir. The reservoir characterization project presented a petrophysical problem because there were almost no modern wireline logs (such as the FDC-CNL) through the Mt. Simon and Elmhurst intervals. The only porosity logs were neutron logs that, in many of the wells, were logged after gas storage had begun. These neutron logs consistently measured lower porosity than the actual porosity because of the "gas effect". Petrophysical methodology was developed in this project to circumvent this difficulty and the method can be used to measure variations in reservoir porosity in other Mt. Simon gas storage reservoirs in Illinois with similar circumstances.

\section{Stratigraphy}

The Mt Simon is over $762 \mathrm{~m}$ (2500 ft) thick in the Herscher area (Buschbach, $1975 \mathrm{p}$. 40). The Mt. Simon is composed of fine- to coarse-grained sandstone with localized 
conglomerates and thin beds of shale and siltstone (Willman et al. 1975). The contact with the overlying Eau Claire Formation is conformable.

The Eau Claire Formation is composed of alternating layers of dolomite, limestone, sandstone, shale, and siltstone. At Herscher Field, the middle of the Eau Claire Formation consists predominantly of shale beds that form an effective seal that prevents gas from migrating from the Mt. Simon into the overlying formations such as the overlying aquifers of the Galesville or St Peter sandstones. The basal member of the Eau Claire Formation, the Elmhurst Sandstone, shown on the Herscher Field type log (Fig. 36), is also used for gas storage in Herscher Northwest Field. The Elmhurst Sandstone is less than $30 \mathrm{~m} \mathrm{(100} \mathrm{ft)} \mathrm{thick} \mathrm{in} \mathrm{the} \mathrm{Herscher} \mathrm{area} \mathrm{and} \mathrm{appears} \mathrm{to}$ gradationally overlie the Mt. Simon Sandstone that is the main gas reservoir.

The Eau Claire is conformably overlain by the Galesville Sandstone, a clean, porous, unfossiliferous sandstone (Buschbach 1964). The Galesville is used for gas storage at Herscher, but, as will be discussed later, this reservoir does not appear to have an adequate seal separating it from shallower freshwater aquifers.

\section{History of the Field}

In the early 1900's the Herscher structure produced oil from the Galena (Trenton) Group (Bell and Cohee 1939). This early Illinois oil field produced from nine individual wells at an average completion depth of $43 \mathrm{~m}(140 \mathrm{ft})$. The best well produced $1 / 2$ barrel of oil per 
day and approximately $896 \mathrm{~m}^{3}\left(32,000 \mathrm{ft}^{3}\right)$ of gas per day. The Herscher oil field was uneconomic, and was abandoned within a few years.

The first mapping of the Herscher structure was based on the St. Peter Sandstone (Athy 1928). In 1952, the Natural Gas Storage Company of Illinois undertook extensive drilling of more than 100 wells to the Galena Group to further map the structural relief and areal extent of the Herscher anticlines (Buschbach and Bond 1974). After these structure test wells were drilled, the company drilled four additional test wells to the Galesville Sandstone. In April 1953, the company began injecting gas into the Galesville Sandstone for gas storage. However, within four months after injection commenced, 33 shallow water wells directly above the Herscher structure began to bubble gas (Benesh et al. 1956). Gas injection into the Galesville Sandstone was immediately stopped. Although the source of the leak was never resolved Buschbach and Bond (1974), and Benesh et al. (1956) attributed to problem to either: 1) a possible hole in casing, 2) a possible fault, or 3) a poor seal. It is our interpretation that the lack of an adequate seal above the Galesville was the most probable cause for the leak since there are other fields with similar leaks from these Cambrian sandstone reservoirs (Buschbach and Bond, 1974).

In 1956, Natural Gas Pipeline Company of America recommenced injection of gas into the Galesville reservoir, taking some measures to control the gas. They kept the reservoir pressure of the Galesville constant by withdrawing water from the periphery of the gas bubble and re-injecting it into the overlying Potosi Dolomite. They also recycled 
gas from vent wells in the overlying Galena Limestone and St. Peter Sandstone. In 1972, the annual withdrawal from the Galesville was over $588 \mathrm{Mmm}^{3}$ (21,000 Mmcf) while leaving a base gas volume of over $1064 \mathrm{Mmm}^{3}(38,000 \mathrm{Mmcf})$ at the end of the withdrawal season (Buschbach and Bond, 1974). These processes are still in use today.

In 1957, testing showed the Eau Claire Formation to be a good seal; thereupon, the operator began storing natural gas into the underlying Mt. Simon Sandstone on the Herscher anticline. Through the early 1960's the Natural Gas Pipeline Company drilled additional Mt. Simon wells and simultaneously continued gas injection into the Mt. Simon reservoir. This reservoir provides a second, important storage unit for the field. In 1972, the annual withdrawal from the Mt. Simon was $392 \mathrm{Mmm}^{3}$ (14,000 Mmcf) while leaving a base gas volume of over $1484 \mathrm{Mmm}^{3}(53,000 \mathrm{Mmcf})$ at the end of the withdrawal season (Buschbach and Bond, 1974).

In 1959 the Herscher NW gas storage project, located four miles northwest of Herscher Field, was begun with the drilling of 32 shallow Galena structure tests. The Herscher NW project is currently inactive because of economic reasons since the structural closure in the Mt. Simon of $18 \mathrm{~m}$ (58ft) (Buschbach and Bond, 1974) and area under closure, were not as large as the near-by Herscher anticline located to the south. 


\section{Structure}

Herscher and Herscher NW Fields are located on an anticlinal feature approximately

$24 \mathrm{~km}$ (15 miles) long and $3.2 \mathrm{~km}$ (two miles) wide that is parallel to and $48 \mathrm{~km}$ (30 miles) northeast of the LaSalle Anticlinorium (Fig. 37). The fields are on the southwest flank of the Kankakee Arch, a broad northwest oriented feature separating the Illinois and Michigan basins.

The best marker for structural control in the Herscher area is the top of the Ordovician age Galena (Trenton) Group because it is both a good correlation marker and 199 wells have been drilled through the Galena. The Mt. Simon horizon has only 103 well penetrations for structural control. All of the formations from the Galena to the Mount Simon are assumed to be structurally conformable to the Galena and, therefore, have a similar structural configuration.

The Galena structure map shows two distinct, northwest-aligned anticlinal closures separated by a saddle (Fig. 38). The southern or Herscher structure has $46 \mathrm{~m}$ (150 ft) of structural relief at the top of Galena Limestone. Herscher is $8 \mathrm{~km}$ (five miles) long and $6.4 \mathrm{~km}$ (four miles) wide at its widest point. There are 4400 acres of structural closure under the active part of the gas storage project. The entire Herscher structure extends over an area of 17,000 acres. The western flank dips steeply whereas the dip of the eastern flank of the structure is gentle. 
The northern or Herscher NW structure is more circular than the elongate shape of Herscher. Herscher NW has slightly more than 15m (50 feet) of structural closure on the Galena horizon. Similar to the southern lobe, Herscher NW has a steeply western and a gently dipping eastern flank. The structural closure on the Galena extends for approximately 3000 acres and has a diameter of $3.2 \mathrm{~km}$ (two miles).

An isopach map of the interval from the Eau Claire correlation point (a good marker on wirline logs) to the top of the Galena (Fig. 39) shows this interval to be $61 \mathrm{~m}$ (200 feet) thicker at Herscher than at Herscher NW. The large variation in thickness may be due to different structural histories. Because of the $61 \mathrm{~m}$ (200 feet) of thickening of this interval, the top of the Mt. Simon at Herscher is $30 \mathrm{~m}$ (100 feet) lower than at Herscher NW (Figs. 40 and 41). This is a reversal of the structural elevations of the top of the Galena Group. There is $23 \mathrm{~m}$ (75 feet) of Mt. Simon structural closure at Herscher, whereas the Herscher NW structure has less than 15m (50 feet) of Mt. Simon closure.

\section{Petrology}

The porous part of the Mt. Simon is composed of a medium- to coarse-grained quartz arenite. The quartz grains are cemented with silica; calcite cement was not observed. The less porous sandstone was fine-grained, silica-cemented and contained 5-10 percent feldspar. 
Based on commercial core analyses from five wells, the Mt. Simon Sandstone has an average horizontal permeability (to air) of $70 \mathrm{mD}$. Eighty percent of the core permeability values fell between $12 \mathrm{mD}$ and $350 \mathrm{mD}$ (Fig. 42). The median porosity was 14 percent and 80 percent of the measurements fell between 10 and 17 percent (Fig. 43).

\section{Petrophysics}

A major goal of this research project was to create an accurate porosity model of the reservoir sandstone that could be used both in volumetric analysis and in reservoir simulations. However, this goal was constrained by the fact that the predominant wireline log suite included only the gamma ray and an older style neutron log. The older neutron logs were commonly calibrated in counts per second and had to be converted into porosity units. Almost all of the wells were drilled and logged in the late 1950s and early 1960s, therefore no modern wireline logs measuring porosity were available in the Mt. Simon interval from the field.

A more serious problem was related to the history of the reservoir as a gas storage target. The first wells were drilled in 1957 and almost simultaneously gas injection was started into the Mt. Simon reservoir. The result of this early gas injection was that the neutron logs were of negligible value in estimating porosity because the neutron tool is strongly affected by natural gas in the reservoir. Calculated porosity in reservoirs filled with either water or oil accurately measures actual porosity because these fluids have 
approximately the same density as hydrogen. However, because natural gas has a much lower hydrogen density, calculated neutron porosity values for a gas-filled reservoir are significantly less than the actual porosity.

An alternative method for calculating porosity was developed using the gamma ray log. Basic gamma ray logs cannot be directly compared with each other from well to well in the field because of varying well bore conditions and incorrect calibrations.

Normalization of these logs can correct this problem. Gamma ray log values from well to well were converted to Vshale values using the Clavier equation (Clavier et al. 1977). This is a normalization technique that scales the gamma ray value from $0 \%$ in pure sandstone to $100 \%$ in a pure shale and allows well to well comparison. The Clavier equation is recommended for use in older strata, whereas the linear gamma ray Vshale equation is better in Tertiary age strata (Clavier et al. 1977).

Neutron porosity values were calculated for all of the wells using standard methods described for the older types of neutron logs (Dull 1991; Brown and Bowers 1957; Swulius 1986). The equations are shown below. In the neutron porosity calculation the shale porosity is assumed to be $30 \%$ and the average porosity in a clean sandstone (small amounts of clay minerals) is estimated from core analyses to be $14 \%$. There is a logarithmic relationship between neutron measurements from the wireline tool and porosity. A shale correction to porosity was made with the Vshale value from the Clavier equation. 


\author{
Vshale Linear \\ Vsh_linear $=($ GR - GRMIN) / (GRmax - GRmin $)$ \\ Vshale Clavier \\ VSHCLV = 1.7 - SQRT $(3.38-($ Vsh_linear + 0.7)^2) \\ Neutron porosity \\ NEU_phi_scaled30 $=10^{\wedge}((\mathrm{m}$ * NEUTRON $)+a)$ \\ Slope $(m)$ and intercept (a) for each well \\ Neutron Shale Correction \\ PHIE = NEU_phi_scaled30 - (VSHCLV * .3) \\ Vshale Porosity Calculations \\ "vshpor"=0.16358143091+("VSHCLV"*-.16764730215)
}

Porosity calculated from the Vshale compares well to neutron porosity and core porosity in off-structure wells located outside the gas storage zone. A transformation equation to calculate porosity directly from Vshale was developed from these core-calibrated wells and applied to the remaining logs in the two fields. One limitation to this method is that the porosity may be slightly underestimated using the Vshale value. As illustrated in the comparative histogram (Fig. 44) the Vshale values reach a maximum, then abruptly stop. They lack the bell-shaped, "normal" distribution that is seen in both the neutron log-derived values and the core values. However, the mean core values and the mean Vshale-transform porosity values in the same interval differ by less than one porosity unit. Comparison of Vshale-derived porosity with neutron porosity is discussed below.

The Knittel M-4 well, for example, was drilled through the gas bubble in Herscher Field. In this well the Vshale porosity minus neutron porosity values are positive (gray fill "gas effect" is noted) and differ by at least $5 \%$. These intervals occur over much of the Mt. 
Simon interval (Fig. 45). The gas-affected values and the non-gas- affected values can be readily differentiated on the cross plot of the neutron porosity and the Vshale porosity.

By way of contrast in another example, the neutron porosity and the Vshale-derived porosity in the Armstrong M-1, an off-structure Herscher Field well, show close agreement (Fig. 46). Gray fill, indicating "gas effect" separation between the Vshale porosity and the lower neutron porosity values, is minimal.

\section{Reservoir Characterization}

The east-west stratigraphic cross section A-A' of Herscher Field (Fig. 47) shows the Mt. Simon to be composed of thick, multiple, stacked sandstone beds. Thin shale beds other than the indicated correlation markers, cannot be readily correlated across the field. Thus, the shales appear to form local baffles rather than compartment barriers. An east to west stratigraphic cross section of Herscher NW Field (B-B' Fig. 48) shows the reservoir-quality Elmhurst sandstone bodies to be only 0.6 to $2.4 \mathrm{~m}$ ( 2 to $8 \mathrm{ft}$ ) thick and separated by thin shales.

The northwest to southeast stratigraphic cross section, C-C', (Fig. 49), located approximately along the axes of Herscher NW and Herscher Fields, shows subtle indentations in the gamma ray log, suggesting that the thick reservoir sandstone beds are composed of stacked, thinner sandstone units. Other than the two shales indicated 
on these cross sections, marker beds within the upper Mt. Simon cannot be traced across the two anticlines. The Elmhurst, which contains reservoir sandstone beds in Herscher NW Field, does not contain significant amounts of sandstone at Herscher (Fig. 50).

The 3D models were created by using surface grids of the elevation of the top of Elmhurst Member of the Eau Claire Formation, the top of the Mt, Simon Sandstone and the Mt. Simon shale marker bed. These surface grids were generated with a 152m (500 foot) grid interval by conformably mapping downward from the top of Galena Group surface. The vertical interval between grid layers is proportional in thickness and is directly related to the isopach interval between the different surfaces. This vertical interval is approximately $1 \mathrm{~m}$ ( 3 feet) thick.

A porosity fence diagram (Fig. 51) shows the lateral variation in reservoir sandstones in the Herscher and Herscher NW model area. The top of this diagram is the top of the Elmhurst sandstone. The Mt. Simon Sandstone top is located at the thin white line by "b". The upper Mt. Simon shale marker bed is located at the white line just below "c". The lower Mt. Simon shale marker is located at the white line just above "f". The levels identified by letters correspond to the slice maps in Figure 52.

The deepest porosity slice map, located just below the lower Mt. Simon shale marker bed, horizon f, (Fig. 52f), shows that widespread high (15 to 16\%) porosity sandstones are common in Herscher NW Field. More laterally variable, 11 to $15 \%$ porosity 
sandstones are seen at Herscher Field. The lower shale marker is discontinuous and forms a potential baffle, not a barrier, to gas flow.

Next, at horizon e (Fig. 52e), the porosity slice map illustrates a clean, widespread sandstone halfway between the upper and lower shale markers. This is a significant gas storage interval in the Herscher Field reservoir. The sandstone appears to have excellent lateral continuity, especially in Herscher NW.

Horizon d (Fig. 52d) is located just below the upper shale marker bed. This horizon consists of a blanket, high-porosity sandstone at Herscher NW Field. Sandstones have variable, good to excellent porosity and lateral continuity in Herscher Field. It is also a significant gas storage interval in both fields.

Horizon c (Fig. 52c) contains thin, discontinuous shales and sandstones near the top of the Mt. Simon. Some sandstones have acceptable reservoir quality (green) in Herscher Field, but the sandstones with better porosity at this horizon occur in Herscher NW Field. Shale beds are discontinuous and form baffles to gas flow.

The uppermost Mt. Simon (Fig 52b) shows good sandstone continuity and porosity (orange) in the Herscher NW Field area and acceptable porosity (green) in Herscher Field. Gas is stored in this interval in both fields. 
The Elmhurst Sandstone is composed of thin, porous sandstone beds in Herscher NW Field that contains gas (Fig. 52a). To the southeast, in Herscher Field, this interval consists of low-porosity, fine-grained sandstones, siltstones, and shales, that are not used for gas storage.

\section{CONCLUSIONS}

The main objectives of this project were to compile and map regional Mt. Simon data from all wells in northern Illinois and to complete highly detailed reservoir characterization studies of two Mt. Simon gas storage fields.

\section{Regional Studies}

- Regional structure maps of the top of the Ordovician Galena Group (also known as the Trenton), the St. Peter Sandstone and the Mt. Simon Sandstone show anticlines that may have potential as new gas storage sites.

- A regional map of water quality in the upper part of the Mt. Simon Sandstone in northern Illinois indicated a progressive increase in total dissolved solids from northern and northwestern Illinois toward the southeast. 


\section{Manlove Field}

- The Manlove Field gas storage field had abundant core and modern wireline logs that allowed an accurate 3-D porosity model of the Mt. Simon Gas storage reservoir.

- A traditional cross plot porosity determination from the neutron and density curves was used to calculate porosity. This was facilitated by abundant core data and many wells with modern compensated porosity logs. Neutron logs from several wells with "gas effect" could not be used in the modeling.

- Reservoir characterization at Manlove Field provided a 3-D visualization showing porous sandstones in a series of stacked tidal channels and bars. The channel sandstones are east-west oriented, approximately $300 \mathrm{~m}$ (1,000 ft) wide and typically 2 to $3 \mathrm{~m}$ ( 6 to $10 \mathrm{ft}$ ) thick. The bar sandstones are north-south oriented, about $1.6 \mathrm{~km}$ ( 1 mile) wide and up to $6.1 \mathrm{~m}$ ( $20 \mathrm{ft})$ thick. Natural gas is primarily stored in the bar facies that occur about $23 \mathrm{~m}(75 \mathrm{ft})$ and more below the top of the Mt. Simon.

- Petrographic studies indicated that the sandstones are cemented primarily with silica overgrowths. The feldspar content increases with decreasing grain size of the sandstones.

\section{Herscher and Herscher NW Fields}

- Well data from Herscher and Herscher NW Fields consisted primarily of older, uncalibrated, neutron wireline logs, making an accurate model of the porosity distribution difficult to create. Because most wells at Herscher Field were drilled 
after gas storage had begun, gas affected the field's neutron logs and conventional methods for calculating porosity values gave anomalously low values in the reservoir intervals.

- An innovative methodology using the gamma ray log was developed to circumvent the problems associated with calculating porosity from the neutron logs in gas-saturated intervals. A transform equation was created using conventionally calculated porosity in off-structure wells, core data and the Vshale curve that could then be applied to the Vshale curves of wells within the field.

- Natural gas is stored in both the overlying Elmhurst Sandstone Member of the Eau Claire Formation and the Mt. Simon in Herscher NW, but only in the Mt. Simon at Herscher. There were no channels like those seen at Manlove Field. The porosity was found to decrease from northwest to southeast in both reservoir units. Shale beds are thin and discontinuous, forming baffles rather than barriers to gas flow.

- Although the variations in data quality made it difficult to directly compare the two gas storage fields in the same formation, an approach using 3-D visualization techniques and different petrophysical methods provided valuable reservoir characterization.

\section{Applications to other Fields}

- The Vshale-to-porosity conversions developed for this study can be used to estimate porosities in other fields where no modern wireline logs exist and gas injection commenced early in the field development. 
- Three-dimensional modeling is the best method for characterizing reservoirs because it highlights reservoir geometries, heterogeneities, seals, and baffles to gas storage.

- Conformable structure mapping techniques such as from the shallow Galena Group allow shallow stratigraphic tests to be used to delineate the configuration of the Mt. Simon Sandstone, which, in most areas has been penetrated by only a few drill holes.

\section{ACKNOWLEDGEMENTS}

We thank Peoples Energy Corporation and Kinder-Morgan, Inc. for their support of the Mt. Simon gas storage reservoir studies. First Data Services digitized many of our well logs. We thank Tom Davis, Ted Kronas, and Kenneth Hopps for useful discussions and data on the gas storage reservoirs.

This study was prepared with the support of the U.S. Department of Energy under award No. DE-FG26-99FT40375. Opinions, findings, conclusions or recommendations expressed in this presentation are those of the authors and do not necessarily reflect the views of the Department of Energy, Kinder-Morgan, Inc., or Peoples Energy Corporation.

We gratefully acknowledge the software support for this research provided by Landmark Graphics via the Landmark University Grant Program. 
At the ISGS, Randy Lipking picked many of the log tops for the northern Illinois wells that were used for the regional maps. Beverly Seyler prepared the SEM images. Richard Geier and Randy Miller provided assistance with data loading and preliminary field models. Jonathon Goodwin, Dennis Kolata, Rob Finley and Bev Seyler reviewed the manuscript and provided many helpful suggestions.

\section{REFERENCES}

Adler, F. J., 1987, Mid-Continent Region: Correlation of Stratigraphic Units of North America (COSUNA) Project, American Association of Petroleum Geologists, Tulsa, Oklahoma.

Atekwana, E.A. 1996, Precambrian basement beneath the central Midcontinent United States as interpreted from potential field imagery; in van der Pluijm, B.A., and Catacosinos, P.A., eds., Basement and Basins of Eastern North America: Boulder, Colorado, Geological Society of America Special Paper 308 p. 33-44.

Atherton, E., 1971, Tectonic development of the eastern interior region of the United States, in Bond, D. C., Background Materials for Symposium on Future Petroleum Potential of NPC Region 9 (Illinois Basin, Cincinnati Arch, and Northern Part of Mississippi Embayment): Illinois State Geological Survey Illinois Petroleum 96, p.29-43. 
Athy, L. F., 1928, Geology and mineral resources of the Herscher quadrangle: Illinois Geological. Survey Bull. 55, 120 p.

Bell, A.H. and G.V. Cohee, 1939, Recent development in Illinois with discussion of producing formations below McClosky "Sand": American Association of Petroleum Geologists, v 23, no. 6, p. 807-822.

Bell, A.H., E. Atherton, T.C. Buschbach, D.H. Swan, 1964, Deep oil possibilities of the Illinois Basin: Illinois State Geological Survey Circular 368, 38 p.

Benesh, M.E., C.M. Clark, W.R. Clark, E.G. Hammerschmidt, D.L. Katz, J.D. Parent, O.S. Seim, and R.D. Sickafoose, 1956, A study of the Herscher Storage Reservoir, Unpublished Report located at the Illinois State Geological Survey library, $74 \mathrm{p}$.

Bickford, M.E., W.R. Van Schmus, and I. Zietz, 1986, Proterozoic history of the midcontinent region of North America: Geology, v. 14, p. 492-496.

Bradbury, J. C. and E. Atherton, 1965, The Precambrian Basement of Illinois: Illinois State Geological Survey Circular 382, 13 p.

Brown, A., and B. Bowers, 1957, The relationship between neutron log deflection and porosity: Canadian Well Log Society, Canadian Symposium Papers 1, no. 39, p. $39-43$. 
Buschbach, T. C., 1964, Cambrian and Ordovician strata of northeastern Illinois: Illinois State Geological Survey Report of Investigations 218, 90 p.

Buschbach, T. C., 1975, Cambrian System, in Willman, et al, Handbook of Illinois Stratigraphy: Illinois State Geological Survey Bulletin 95, p. 32-46.

Buschbach, T.C. and D.C. Bond, 1974, Underground storage of natural gas in Illinois1973: Illinois State Geological Survey, Illinois Petroleum 101, 71 p.

Byers, C. W., 1978, Depositional environments of fine-grained upper Cambrian lithofacies, in Odom, E., (ed.), Lithostratigraphy, petrology, and sedimentation of Late Cambrian-Early Ordovician rocks near Madison, Wisconsin: Society of Economic Paleontologists and Mineralogists, Great Lakes Section, Field Trip Guidebook No. 3, p. 67-82.

Clavier, C., G. Coates, and J. Dumanoir, 1977, The theoretical and experimental bases for the "Dual Water" model for the interpretation of shaly sands: Society of Petroleum Engineers Preprint No. 6859, 52nd Annual Meeting, 18 p. 
Driese, S. G., C. W. Byers, and R.H. Dott, Jr., 1981, Tidal deposition in the basal upper Cambrian Mt. Simon Formation in Wisconsin: Journal of Sedimentary Petrology, v. 51 , no. 2 , p. $367-381$.

Droste, J.B. and R.H. Shaver, 1983, Atlas of early and middle Paleozoic paleogeography of the southern Great Lakes area: Indiana Department of Natural Resources, Geological Survey Special Report 32, 32 p.

Dull, D.W., 1991, Calibrating old, new logs to cores needed for planning $\mathrm{CO}_{2}$ flood: Oil and Gas Journal, p. 58-64.

Houseknecht, D.W. and F. G. Ethridge, 1978, Depositional history of the Lamotte Sandstone of southeast Missouri: Journal of Sedimentary Petrography, v. 48, p.575-586.

Huber, M. E., 1975, A paleoenvironmental interpretation of the Upper Cambrian Eau Claire Formation of west-central Wisconsin (unpublished M. S. thesis): University of Wisconsin-Madison, $110 \mathrm{p}$.

Kolata, D.R., 1991, Illinois Basin Geometry, in Leighton, M.W., D.R. Kolata, D.F. Oltz, and J.J. Eidel (eds.), Interior Cratonic Basins: American Association of Petroleum Geologists Memoir 51, p. 197. 
Kolata, D. R, and others, (in prep.) Bedrock Geology Map of Illinois (Scale 1:500,000): Illinois State Geological Survey.

McBride, J.H., D. R. Kolata, and T. G. Hildenbrand, 2003, Geophysical constraints on understanding the origin of the Illinois basin and its underlying crust: Tectonophysics, v. 363. p. 45-78.

Nelson, W. J., 1995, Structural features in Illinois: Illinois State Geological Survey Bulletin 100, 144p.

Pipeline Report, 1994, U. S. underground natural gas storage fields: Oil and Gas Journal, September 12, 1994, p. 47.

Sargent, M.L., 1991, Sauk Sequence, Cambrian System through Lower Ordovician Series, in Leighton, M.W., D.R. Kolata, D.F. Oltz, and J.J. Eidel (eds.), Interior Cratonic Basins: American Association of Petroleum Geologists Memoir 51, p. 75-85.

Sargent, M.L. and Lasemi, Z., 1993, Tidally dominated depositional environment for the Mt. Simon Sandstone in central Illinois: Great Lakes Section, Geologic Society of America, Abstracts and Programs, v. 25, no.3, p, 78.

Seilacher, A., 1967, Bathymetry of trace fossils: Marine Geology, v. 5, p. 413-429. 
Shaver, R. H., 1985, Midwest Basins and Arches: Correlation of Stratigraphic Units of North America (COSUNA) Project, American Association of Petroleum Geologists, Tulsa, Oklahoma.

Sloss, L.L., 1963, Sequences in the cratonic interior of North America: Geological Society of America Bulletin, v.74, p.93-114.

Swann, S. H., and H. B. Willman, 1961, Megagroups in Illinois: Bulletin of the American Association of Petroleum geologists, v. 45, no. 4, p. 471-483.

Swulius, T.M., 1986, Porosity calibration of neutron logs, Sacroc Unit: Journal of Petroleum Technology, no 4, p. 468-476.

Templeton, J. S., 1950, The Mt. Simon Sandstone of northern Illinois: Illinois Academy of Science Transactions, v. 43, p. 151-159.

Twenhofel, W. H., G.O Raasch, and F. T. Thwaites, 1935, Cambrian strata of Wisconsin: Bulletin of the Geological Society of America, v. 46, p. 1687-1744.

Walcott, C. A., 1914, Cambrian geology and paleontology: Smithsonian Misc. Coll., v. 57 , p. $345-412$. 
Willman, H.B., E. Atherton, T.C. Buschbach, C. Collinson, J.C. Frye, M.E. Hopkins, J.A. Lineback, and J.A. Simon, 1975, Handbook of Illinois Stratigraphy: Illinois State Geological Survey, Bulletin 95, 261 p.

William, H.B., and Templeton, J.S, 1952, Cambrian and Lower Ordovician Exposures in Northern Illinois: Illinois Geological Survey Circular. 179, p. 109-25.

Workman, L.E., and A.H. Bell, 1948, Deep drilling and deeper oil possibilities in Illinois: American Association of Petroleum Geologists Bulletin v. 32 no. 11, p. 20412062.

\section{List of acronyms and abbreviations}

FDC-CNL- Compensated Formation Density and Compensated Neutron Log GR- Gamma Ray Log

ISGS- Illinois State Geological Survey

U of I- University of Illinois

Vshale- A calculated shale volume based on the Gamma Ray log SI- "Le Systeme International d'Unites" 


\section{Figure Captions}

Figure 1 Stratigraphic Column of Ordovician Through Precambrian rocks in

Northern Illinois. Arrows point to the formations discussed in this report (from Kolata et al, in prep).

Figure 2 Cambrian Correlation Chart for Midwest states adjacent to Illinois.

Figure 3 Regional Structure Map- Top of Galena Group. Contour interval is 100 .

Figure 4 Regional Structure Map- Top of St. Peter Sandstone. Contour interval is 100 .

Figure 5 Regional Structure Map- Top of Mt. Simon Sandstone. Contour interval is 100 .

Figure 6 Regional Isopach Map- Top of Galena Group Carbonates to Top St. Peter Sandstone

Figure 7 Regional Mt. Simon Sandstone Salinity Map

Figure 8 Regional Variation of Mt. Simon Porosity with Depth. 
Figure 9 Top of Mt. Simon Sandstone Structure Map, Manlove Field. The locations of all Mt. Simon wells are indicated. Wells with a ladder-like symbol show the traces of delineated wells. The + mark indicates the well location at total depth. The structure conforms to the shape developed from the Galena level. The contour interval is $6.1 \mathrm{~m}$ (20ft).

Figure 10 Manlove Field Type Log. Correlation marker beds used the Mt. Simon reservoir characterization include a laterally continuous shale ( $L 120)$, the top of the Mt. Simon Sandstone, the top of the Elmhurst sandstone member of the Eau Claire Formation, and a laterally correlative point in the Eau Claire. Gas is stored at Manlove Field in the more massive sandstones above the L 120 marker.

Figure 11 East-West Stratigraphic Log Cross-section Manlove Field. Vshale and calculated porosity for each well are shown with the lateral correlation of the top of the Mt. Simon and the L 120 marker shale.

Figure 12 Top of Galena Group Structure Map, Manlove Field. Wells reaching the Galena include all the Mt. Simon wells in addition to a number of shallower test holes that were specifically drilled to delineate the nature of the structural closure. The contour interval is $6.1 \mathrm{~m}(20 \mathrm{ft})$.

Figure 13 3D View of Mt. Simon Well Control, Manlove Field. The 121 wells were used to construct the 3D porosity model. The surface shown is the L120 marker. 
Figure 14 Core photograph of Cross-bedded Sandstone Facies. This medium to coarse-grained, cross-bedded sandstone is the primary reservoir facies. Cross-beds may be tabular- (A) or trough- (C) shaped. B) The bases of the cross-beds may have some quartz granules. The thickness of the tabular cross-bed sets range from 30 to $100 \mathrm{~cm}$ ( 1 to $3 \mathrm{ft})$. Trough cross-bed sets typically are only 5 to $15 \mathrm{~cm}$ thick ( $2 \frac{1 / 2 "}{12}$ to 6 "). Core from the Hazen \#5 and J. Williams \#4 wells.

Figure 15 Core photograph of Bioturbated Sandstone Facies. Vertical Skolithos burrows in medium to coarse sandstone may obliterate most of the original stratification. These burrows are formed from filter feeders that live a high energy substrate and intercept food from the moving water that lies above. Core from the Hazen \#5 and $\mathrm{J}$. Williams \#4 wells.

Figure 16 Core photograph of Deformed Sandstone Facies. Structureless to swirly bedded sandstone strata formed from liquefied sandstone and subsequent fluid escape. Core from the Hazen \#5 well.

Figure 17 Core photograph of Interstratified Fine Sandstone and Shale Facies. Heterolithic low energy sediments deposited on the tidal flats. Small round horizontal burrows of Planolites are filled with fine sandstone. The shale content varies from very high as in (A) to very thin laminae (B \& C). Sand-filled mudcracks are seen in (B). Clusters of very thin shale laminae alternating with laminae and thin-beds of very fine 
sandstone (C) are typical of tidal rhythmites. Core from the J Williams \#4 well at (A) 1278m (4192 ft), (B) 1218.8m (3996 ft) and (C) $1219.0 \mathrm{~m}$ (3997 ft).

Figure 18 Core photograph of Laminated Shale Facies. Laminated, dark gray shale with thin laminae of siltstone and local very fine sandstone or siltstone-filled Planolites burrows. Core from the Hazen \#5 well at $1277 \mathrm{~m}(4187 \mathrm{ft})$.

Figure 19 Geophysical log of J. Williams \#4 Well. Burrow types, grain-size trends, and gas- and water- bearing zones are annotated. Injected gas is identified where density porosity and neutron porosity have divergent values (colored yellow). Discrete intervals show "gas effect" log separation in several clean sandstones. Individual gasbearing sandstones appear to have basal water sands (colored blue) where the density and neutron porosities have similar values. This suggests that individual gas sands may be compartmentalized.

Figure 20 North-South Stratigraphic Log Cross-section, Manlove Field. Vshale and calculated porosity for each well are shown with the lateral correlation of the top of the Mt. Simon and the L 120 marker shale.

Figure 21 Depositional Model Block Diagram for Manlove Field Area. A general barrier-lagoon-tidal flat model is shown here. Exiting from the major tidal channel 
system separating the barriers is an ebb-tidal delta deposit. Long-shore currents from bottom to top in this diagram bring in sediment from an alluvial system that is outside the model area. Tidal channels cut through the lagoonal area and have sinuous paths. Thin intertidal sand flats and mud flats rim the lagoon. Progradation of the barrierlagoon-flat system creates laterally continuous barrier sands, discontinuous channel sands, and dissected intertidal sand and mud flats.

Figure 22 Thin Sections of Mt. Simon Sandstones. A) Clean, moderately wellsorted, medium to coarse sandstone cemented with euhedral quartz overgrowths. B) Interlayered medium-coarse sandstone and fine sandstone. The dark grains are stained k-feldspar grains that have been segregated by size into the fine grain fraction. C. Interlaminated very fine sandstone and clayey siltstone. The dark grains are stained k-feldspar. The light gray, extremely fine-grained material is detrital clay. Porosity is filled with blue-dyed epoxy. Samples are from the J Williams \#4 well, at the indicated depths. Bar scales are $0.25 \mathrm{~mm}$ long.

Figure 23 Thin Sections of Mt. Simon Coarse-grained Sandstones. Quartz grains are cemented by euhedral quartz overgrowth cement. The original grains are well rounded. Primary porosity is filled with blue-dyed epoxy. Samples are from the J Williams \#4 well at the indicated depths. Bar scales are $0.125 \mathrm{~mm}$ long. 
Figure 24 SEM Image of Reservoir Sandstone. Reservoir sandstone with euhedral quartz overgrows and an open pore system. Bar scale is $0.1 \mathrm{~mm}$ long. Sample from the J Williams \#4 well, 1239.2m (4062.8ft).

Figure 25 SEM Image of Diagenetic Clay Minerals in Reservoir Sandstone. Clay minerals are sparse in the Manlove reservoir sandstones. Very isolated patches of diagenetic illite can be seen coating some quartz overgrowths. This image is from a small area just below the center of the previous figure. Bar scale is $0.01 \mathrm{~mm}$ long.

Figure 26 Core and Calculated Log-Derived Porosity Histograms. Mean (dashed vertical line) and distribution of cored porosity (red) and density-neutron porosity (green) agree well.

Figure 27 Three Dimensional Fence Diagram of Porosity Model for Manlove Field. View is toward the north-north-east and shows the steep west flank and gentle east flank of the doubly plunging anticlinal trap. The spill point lies in the northeast part of the field.

Figure 28 East-West Cross-section of Porosity at Manlove Field Figure 29 North-South Cross-section of Porosity at Manlove Field 
Figure 30 Horizontal Slice Map of Manlove Field Porosity Model- 1220 m (4000 ft). A high porosity channel sand crosses the crest of the field. In the J Williams \#4 well core, this sandstone contains abundant Skolithos burrows, a few thin shale intraclasts and is medium to coarse grained. Lateral to this illustrated reference well, the facies have low porosity and are interpreted to be lagoonal or intertidal mud flats. The interval lies above the gas storage reservoir.

Figure 31 Horizontal Slice Map of Manlove Field Porosity Model- 1230 m (4034 ft). A bifurcating, high porosity zone interpreted as a west to east flowing channel system, crosses the center of the field. Core in the $\mathrm{J}$ Williams \#4 reference well at this depth contains coarse to very coarse-grained, porous sandstone with thin cross-bed sets and local Skolithos burrows. To the north and south of this well lie lower porosity facies. The FDC-CNL log indicates that this sand lies just above a thin shale and the main gas reservoir.

Figure 32 Horizontal Slice Map of Manlove Field Porosity Model- 1237m (4056 ft). A widespread, porous sandstone occurs in this upper gas storage interval. The sandstone is cross-bedded, and coarse to very coarse-grained. Just to the west of the reference well is an area with excellent porosity that trends north-south that is interpreted as a barrier island deposit Further to the west are two narrow high porosity areas oriented perpendicular to the barrier that are interpreted as tidal channel deposits. 
Figure 33 Horizontal Slice Map of Manlove Field Porosity Model- 1260 m (4132 ft). An east-west oriented, sinuous, high porosity sandbody crosses the center of the field just to the south of the reference well in interpreted as a tidal channel deposit. It is joined by a channel or remnant barrier island sand from the north. To the east is another barrier island may exist. The lithology in this interval in the reference well consists of coarse to very coarse-grained sandstone that is cross-bedded.

Figure 34 Horizontal Slice Map of Manlove Field Porosity Model- 1277m (4187 ft) This occurs at the L120 marker level and shows the continuity of this shale and interbedded shale and fine sandstone, low porosity interval. Sand-filled Planolites burrows are common in core of this interval in the reference well. Deposition was likely in a back-barrier, tidally influenced lagoon or intertidal mud flat.

Figure 35 Base Map of Herscher and Herscher NW Fields. Geologic cross sections and wells referenced in this report are shown. The insert map shows the location of the Herscher project in relation to the state of Illinois.

Figure 36 The type log for the Herscher Field shows the important reservoir sandstone used to inject gas. Gas is injected into both the Elmhurst and Mt. Simon Sandstone but in the Knittle No 4 well only the Mt. Simon sandstone is an injection target., 
Figure 37 Regional structural features in the Illinois Basin showing the location of Hersher and Herscher NW gas storage fields (Modified from Nelson 1995).

Figure 38 Structure on top of the Galena Group at Herscher and Herscher NW Fields. The shown well locations all have Galena Group surface elevations used in the

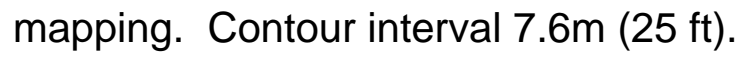

Figure 39 Isopach of the interval between the top of Galena and the Eau Claire correlation point. Only wells penetration through the entire interval are shown. Contour interval is $7.6 \mathrm{~m}(25 \mathrm{ft})$.

Figure 40 Structure on the top of the Mt. Simon Sandstone at Herscher and Herscher NW Fields. Only wells that penetrated the Mt. Simon surface are shown in this figure. Contour interval $7.6 \mathrm{~m}(25 \mathrm{ft})$

Figure $41 \quad 3-D$ view of Herscher and Herscher NW Fields illustrates the well control at the reservoir horizon and the configuration of the lower Mt. Simon shale correlation marker. The Mt. Simon reservoir sandstone at Herscher NW Field is structurally about $30 \mathrm{~m}$ (100 ft) higher than at Herscher Field. View is toward the north-northeast.

Figure 42 Cumulative distribution of core permeability from the Mt. Simon Sandstone at Herscher Field. 
Figure 43 Cumulative distribution of core porosity from the Mt. Simon Sandstone at Herscher Field.

Figure 44 Histogram showing the distribution of porosity using three different porosity calculations.

Figure 45 a) Wireline curves of Vshale and porosity calculated using the neutron log and Vshale curve from the Knittel No 4 well. b) Cross plot of the Vshale and the neutron porosity.

Figure 46 a) Wireline curves of Vshale and porosity calculated using the neutron log and Vshale curve from the Armstrong No. 1 well. b) Cross plot of the Vshale and the neutron porosity.

Figure 47 Stratigraphic cross section A-A' through the Herscher NW anticline with the top of the Elmhurst Sandstone marker as the datum. Curves show the normalized gamma ray and the calculated porosity values and indicate the vertical and lateral variation of the reservoir sandstones. Location of the cross section shown in Figure 35.

Figure 48 Stratigraphic cross section B-B' through the Herscher anticline with the top of the Elmhurst Sandstone marker as the datum. Curves show the normalized gamma ray and the calculated porosity values and indicate the vertical and lateral variation of the reservoir sandstones. Location of the cross section shown in Figure 35. 
Figure 49 Stratigraphic cross section $\mathrm{C}^{-\mathrm{C}^{\prime}}$ along the axes of both Herscher and Herscher NW anticlines with the top of the Elmhurst Sandstone marker as the datum. Curves show the normalized gamma ray and the calculated porosity values and indicate the vertical and lateral variation of the reservoir sandstones. Location of the cross section shown in Figure 35.

Figure 50 Elmhurst sandstone isolith shows the thickest Elmhurst sandstone to occur in the Herscher NW Field. Almost no sandstone is present in the southeast part of the mapping area in Herscher Field.

Figure $513-\mathrm{D}$ visualization of the porosity distribution at Herscher Field. The letters on the cross section show the approximate vertical interval from which the stratigraphic slices were derived.

Figure 52 Stratigraphic slices showing porosity distribution at the Herscher area. 


\section{Appendices}

\section{Appendix 1. Modal Analyses of Manlove Field, J Williams \#4}

(based on 300 points per thin-section)

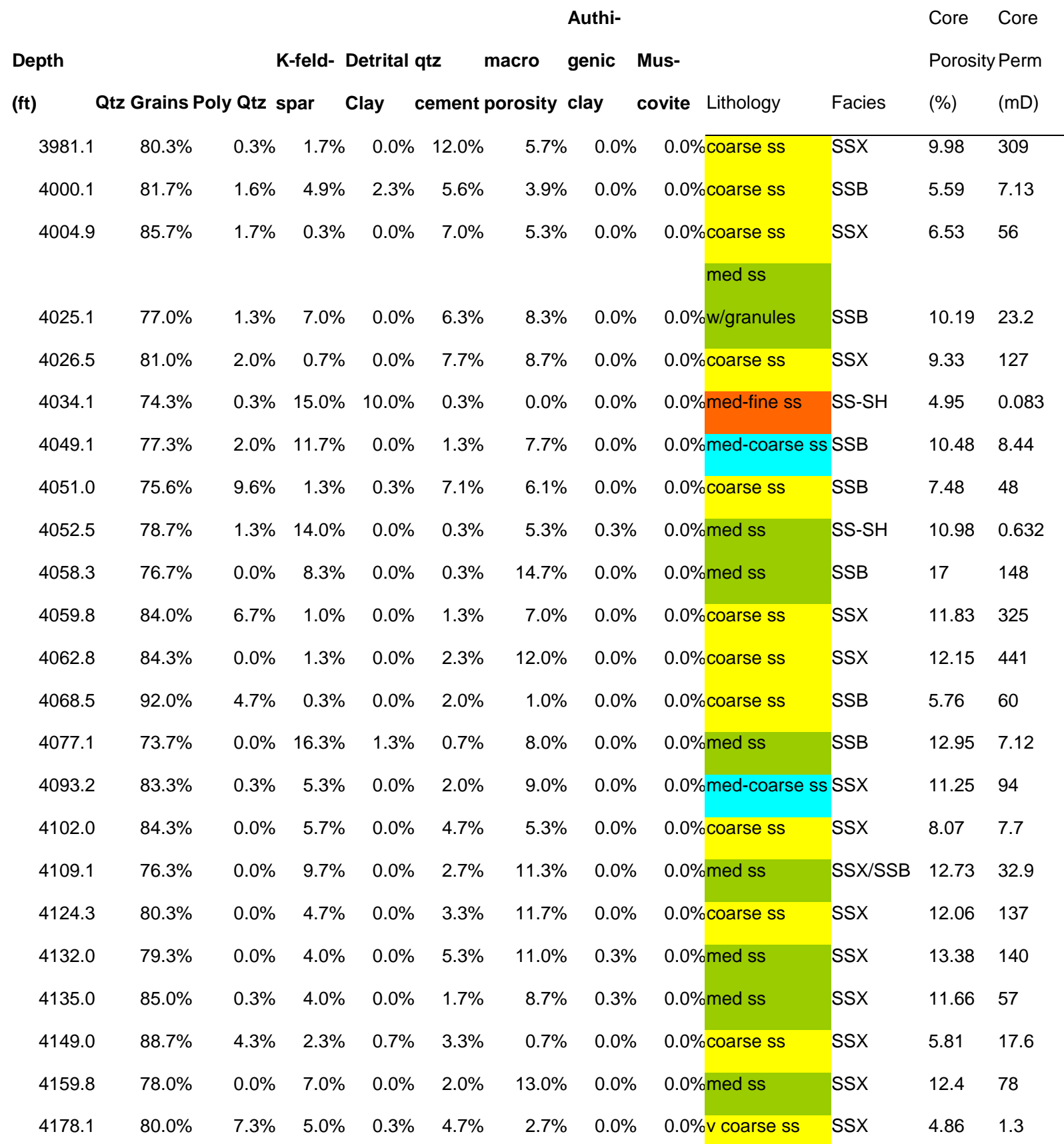




$\begin{array}{llllllllllllll}4180.0 & 80.0 \% & 0.0 \% & 1.0 \% & 0.0 \% & 16.0 \% & 3.0 \% & 0.0 \% & 0.0 \% \text { med-coarse ss SSX } & 6.52 & 0.363 \\ 4185.1 & 82.7 \% & 0.0 \% & 1.3 \% & 0.0 \% & 12.3 \% & 3.7 \% & 0.0 \% & 0.0 \% \text { med ss } & \text { SSX } & 5.3 & 6.17 \\ 4191.0 & 67.7 \% & 0.0 \% & 16.3 \% & 10.7 \% & 0.3 \% & 3.3 \% & 1.7 \% & 0.0 \% \text { med-fine ss } & \text { SS-SH } & 10.17 & 0.103 \\ & & & & & & & & \text { fine ss w/ } \\ 4195.2 & 66.0 \% & 0.0 \% & 21.3 \% & 7.0 \% & 4.3 \% & 0.7 \% & 0.0 \% & 0.7 \% \text { shale lams } & \text { SS-SH } & 6.28 & 0.034 \\ 4197.0 & 81.0 \% & 0.3 \% & 0.7 \% & 0.0 \% & 15.0 \% & 0.7 \% & 2.3 \% & 0.0 \% \text { med ss } & \text { SSX } & 5.14 & 0.117 \\ 4207.1 & 78.3 \% & 0.0 \% & 5.0 \% & 0.0 \% & 7.0 \% & 9.7 \% & 0.0 \% & 0.0 \% \text { coarse ss } & \text { SSX } & 10.28 & 60 \\ 4209.1 & 83.0 \% & 1.3 \% & 2.3 \% & 0.0 \% & 3.0 \% & 10.3 \% & 0.0 \% & 0.0 \% \text { coarse ss } & \text { SSD } & 12.59 & 151 \\ 4217.4 & 79.3 \% & 3.7 \% & 1.3 \% & 0.0 \% & 13.0 \% & 2.7 \% & 0.0 \% & 0.0 \% \text { coarse ss } & \text { SSX } & 5.9 & 3.25\end{array}$

Note: SSX-Cross-bedded Sandstone

SSB- Bioturbated Sandstone

SSD- Soft Sediment Deformed Sandstone

SS-SH- Interlaminated Fine Sandstone and Shale 


\section{Appendix 2a. Core Description, Peoples Gas Light \& Coke, J. Williams \#4 Well}

Sec. 16-T21N, R7E

Champaign County

Logged by David G. Morse, July 16, 2001

API 120192389600

TOP OF CORE $3980.0 \mathrm{ft}$

\section{Thickness Top Bottom}

$4.93980 \quad 3984.9 \quad$ Coarse sandstone, cross-bedded, hematite mottled parallel to bedding, a few very coarse sandstone grains in local thin beds, 8"-12" high cross-bed sets. mm-scale mudstone drapes at base. Good porosity (9\%).

$1.9 \quad 3984.93986 .8 \quad$ Buff with pale greenish interbedded coarse sandstone and medium sandstone. Low porosity somewhat mottled to structureless. Only fair sorting. Vague horizontal bedding with faint vertical burrows(?).

$1.8 \quad 3986.83988 .6 \quad$ Medium to coarse sandstone with red and green mudstone laminations, krinkly bedding generally tight, $1 / 4$ " circular horizontal burrows. Medium sandstone interclasts in coarse sandstone, thin bedded.

$2.5 \quad 3988.63991 .1 \quad$ Coarse to medium sandstone interbeds, coarse, porous, medium sandstone, non-porous, vertical mottling at top, buff colored with coarser sandstone having greenish tinge.

$0.1 \quad 3991.13991 .2 \quad$ Interbedded medium sandstone and dark gray shale and shale intraclasts.

0.8 $3991.23992 .0 \quad$ Coarse sandstone with gray green mudstone drape and greenish color to sandstone.

$1.4 \quad 3992.03993 .4 \quad$ Interbedded dark gray shale laminae, bioturbated or mudcracks (sand filled) and medium and coarse sandstone thin beds. Delicate horizontal, laminated shale partings.

3.1 3993.4 3996.5 Mottled, buff to pale greenish white, coarse sandstone, non-porous. 


\section{Thickness Top Bottom}

$0.6 \quad 3996.53997 .1$ Interbedded medium sandstone and very fine dark gray shale laminations.

$5.8 \quad 3997.14002 .9 \quad$ Generally homogeneous medium and coarse light buff sandstone. Vertical mottling (locally), a few thin green-gray shale intraclasts. One thin interval of cross-bedding at 01.5. Fairly tight. Coarsest sandstone has a pale greenish cast. Sandstone is stylolitic at 3997.5.

$0.8 \quad 4002.94003 .7 \quad$ Cross-bedded coarse sandstone.

$0.7 \quad 4003.74004 .4 \quad$ Brecciated sandstone.

$0.8 \quad 4004.44005 .2 \quad$ Cross-bedded coarse sandstone.

0.3 4005.2 4005.5 Medium sandstone with brown shale laminations, sandstone brown to buff and another greenish brown. Non-porous.

$2.5 \quad 4005.54008 .0 \quad$ Mottled poorly sorted medium to very coarse sandstone with vertical burrows, thin laminae, 1" mudstone at 4006.5

$1.24008 .04009 .2 \quad$ Cross-bedded, coarse sandstone.

8.0 4009.2 4017.2 Mottled coarse sandstone and some medium sandstone with vertical disruptions, locally cross-bedding remnants seen, especially in coarse sandstone intervals.

1.1 4017.2 4018.3 Interbedded brownish and dark greenish gray siltstone with rounded horizontal burrows and thin beds of buff to pale orange very fine sandstone and medium sandstone.

3.2 4018.34021 .5 Coarse sandstone, faint horizontal bedding, disrupted and mottled, cross-bedded below then becomes medium sandstone toward base. $1 / 2$ " dark gray shale at 4019.5 .

3.1 4021.54024 .6 Interbedded fine to medium buff sandstone with black wispy shale fine laminations, sands commonly horizontalburrowed, 4023.0' has vertical burrows.

9.4 4024.6 4034.0 Coarse to very coarse light buff sandstone, commonly cross-bedded with thin beds of medium to fine sandstone. Cross-sets typically only a few inches high. Locally contains vertical burrows. Some more poorly stratified beds contain granules to $2 \mathrm{~mm}$. 


\section{Thickness Top Bottom}

$1.5 \quad 4034.04035 .5 \quad$ Interlaminated medium to fine sandstone and thinly laminated black shale. Abundant burrows - sand filled, horizontal shale laminae may be rhythmic with short intervals of thin bedded sandstone then very thin laminations of sandstone and shale.

$4.9 \quad 4035.54040 .4 \quad$ Missing.

$0.5 \quad 4040.44040 .9$ Cross-bedded coarse sandstone.

$5.1 \quad 4040.94046 .0 \quad$ Weakly bedded coarse sandstone with vertical burrowed intervals.

1.3 4046.0 4047.3 Mostly medium to coarse buff sandstone with stylolites weakly bedded.

$0.2 \quad 4047.34047 .5 \quad$ Horizontally bedded coarse sandstone.

2.0 4047.54049 .5 Highly burrowed and stylotized medium sandstone weakly bedded.

$0.7 \quad 4049.54050 .2 \quad$ Bedded and cross-bedded coarse sandstone.

1.6 $4050.24051 .8 \quad$ Interbedded fine, medium and coarse sandstone with abundant vertical burrows.

$1.14051 .84052 .9 \quad$ Interbedded fine and medium sandstone with shale stringers (microlaminated black shale) in burrows or $\mathrm{v}$ shaped cracks.

4.7 $\quad 4052.94057 .6 \quad$ Cross-bedded poorly sorted coarse sandstone with fine matrix and $2 \mathrm{~mm}$ grains of quartz. Top is mottled. Top of main gas storage reservoir. 1" pyrite nodule at 4056.5 .

$1.9 \quad 4057.64059 .5 \quad$ Fine to medium sandstone with vertical burrows, fluid escape (?) structures.

12.0 $4059.54071 .5 \quad$ Cross-bedded coarse sandstone, very thin black shale stringers at 4064.6 and 4065.9. Sandstone includes medium sandstone laminae and foresets, and floating very coarse grains to $3 \mathrm{~mm}$, and local shale intraclasts.

1.6 4071.54073 .1 Mostly medium sandstone with wispy black shale whiskers. 


\section{Thickness Top Bottom}

3.7 $\quad 4073.14076 .8$ Coarse sandstone with 2" very coarse sandstone at base, mostly cross-bedded with a few local stylolites.

1.9 $\quad 4076.84078 .7 \quad$ Fine to medium sandstone with burrowed black shale interbeds one to three inches thick. Sandstone is bioturbated. Shales are finely laminated and krinkly.

$1.9 \quad 4078.74080 .6 \quad$ Cross-bedded coarse sandstone.

$1.1 \quad 4080.64081 .7$ Fine, medium, and coarse sandstone with a few shale whiskers at top.

3.5 4081.74085 .2 Coarse cross-bedded sandstone with quartz granules.

0.7 $\quad 4085.24085 .9 \quad$ Bioturbated medium to fine sandstone with some floating coarse sandstone grains, very fine shale whiskers at top.

$2.5 \quad 4085.94088 .4 \quad$ Coarse cross-bedded sandstone. Granules to $4 \mathrm{~mm}$ at base. Weakly bedded, very bioturbated locally - some stylolites.

1.6 $4088.44090 .0 \quad$ Fine to medium buff sandstone with coarse sandstone thin beds. Some fine sandstone with floating granules and stylolites.

$14.9 \quad 4090.04104 .9 \quad$ Coarse, cross-bedded sandstone, fair sorting - local granule layers $1 / 2$ " thick. Sandstone with fine black shale whiskers at 4096.9', gray shale intraclasts 4095.8 . Possibly over steepened cross-sets 4100-4101. In general, cross sets appear to be only a few inches high. $93^{\prime}-95$ ' = 1 set 24 inches high. $1 / 4$ " black shale laminated at 4103.9 .

0.4 $4104.94105 .3 \quad$ Interbed, fine sandstone and laminated black shale.

$2.5 \quad 4105.34107 .8$ Coarse sandstone, weak bedding at top and cross-bedded at base with granules.

3.7 4107.84111 .5 Medium sandstone with whisker shale interbeds at 4108.9, 4110.1, 4111.0. Clastic dike (escape structures?) at 4110.9 with some granules to $3 \mathrm{~mm}$; sandstone is bioturbated at base.

4.0 $\quad 4111.54115 .5 \quad$ Cross-bedded coarse sandstone with some granules. 


\section{Thickness Top Bottom}

$0.9 \quad 4115.54116 .4 \quad$ Fine to medium sandstone with black shale fine lamination. Sandstone is homogeneous with some ripples.

2.0 $4116.44118 .4 \quad$ Medium to coarse cross-bedded sandstone, black shale intraclasts at 4117.0.

$1.8 \quad 4118.44120 .2 \quad$ Interlaminated black shale and fine to medium sandstone. One inch of shale at 4118.5. Two shale beds at 4119.34119.7. Bioturbated shale with sand filling.

$6.9 \quad 4120.24127 .1 \quad$ Cross-bedded and ripple bedded, fair sorted medium to coarse sandstone, a few granule trains along bed bases. Some soft sediment deformation (over steep beds at 4121.7). Shale clasts at base, granules sprinkled throughout.

2.0 $4127.14129 .1 \quad$ Cross-bedded fair sorted coarse sandstone with ripples.

1.7 $\quad 4129.14130 .8$ Medium to coarse sandstone becoming coarse and homogeneous cross-bedded at base.

3.6 $4130.84134 .4 \quad$ Coarse sandstone with local beds very coarse sandstone, cross-bedded.

1.0 4134.4 4135.4 Medium sandstone planar and ripple bedded, shale chips at top.

3.6 $\quad 4135.44139 .0 \quad$ Coarse cross-bedded sandstone with scattered granules.

$0.1 \quad 4139.04139 .1 \quad$ Black shale and fine sandstone laminations, bioturbated sand filled.

1.9 $4139.14141 .0 \quad$ Cross-bedded coarse sandstone, finer at top with more diffuse bedding.

0.8 4141.0 4141.8 Medium sandstone with grains of coarse sandstone, weakly ripple bedded.

$0.7 \quad 4141.84142 .5 \quad$ Interbedded medium to coarse sandstone and bioturbated black shale-sandstone is cross-bedded.

$0.4 \quad 4142.54142 .9 \quad$ Coarse cross-bedded sandstone. 


\section{Thickness Top Bottom}

4.2 $4142.94147 .1 \quad$ Interbedded fine, medium and coarse sandstone with black shale whiskers and laminations. Soft sediment deformation at 4146.5. Coarser sands are rippled and cross-bedded. Fine sands are nearly structureless, though may have coarse sandstone grains in a lamination.

1.6 4147.14148 .7 Medium to coarse sandstone cross-bedded to soft sediment deformation.

$2.5 \quad 4148.74151 .2 \quad$ Ripple bedded coarse sandstone. 1/4 " black shale at base.

4.8 4151.2 4156.0 Cross-bedded coarse sandstone - local granules to $4 \mathrm{~mm}$.

$0.5 \quad 4156.04156 .5 \quad$ Missing.

0.3 4156.54156 .8 Medium to coarse sandstone with bioturbated black shale.

7.0 4156.84163 .8 Cross-bedded coarse to very coarse sandstone, includes thin intervals of coarse then medium sandstone.

1.14163 .84164 .9 Medium sandstone, thin beds with black shale whisker laminations, slight bioturbation.

$12.9 \quad 4164.94177 .8 \quad$ Medium and coarse cross-bedded sandstone.

$0.1 \quad 4177.84177 .9 \quad$ Laminated green-gray shale.

0.3 4177.94178 .2 Very coarse sandstone - cross-bedded, well cemented.

1.3 4178.24179 .5 Vertical burrows in medium sandstone interbedded with dark green-gray shale which is finely laminated. Burrows up to $1 / 4$ " wide and one inch high.

3.1 4179.54182 .6 Medium sandstone, with some coarse grains - $1 / 4$ " thick granule lags.

$0.1 \quad 4182.64182 .7 \quad$ Blackish-green laminated shale.

1.0 4182.74183 .7 Rippled medium to coarse sandstone.

0.7 $4183.74184 .4 \quad$ Coarse sandstone, cross-bedded, granules at base.

4.4 4184.4 4188.8 Medium to coarse sandstone with $1 / 2$ " thick zone at top with whiskers of black shale. 


\section{Thickness Top Bottom}

$0.3 \quad 4188.84189 .1 \quad$ Interbedded, bioturbated black shale and medium sandstone. Shale is finely laminated.

1.9 4189.1 4191.0 Fine to medium sandstone, vertical burrows 3/16 “ diameter and one inch high.

4.6 $4191.04195 .6 \quad$ Interlaminated black and dark greenish-black shale and fine to medium sandstone. Shale has irregular circular horizontal burrows $-1 / 2$ " diameter. Sandstone has vertical burrows as above.

$1.9 \quad 4195.64197 .5$ Cross-bedded medium to coarse sandstone. Fine pyrite balls $1 / 64$ " diameter at 4187 .

$0.1 \quad 4197.54197 .6 \quad$ Black laminated shale.

3.6 $4197.64201 .2 \quad$ Coarse cross-bedded sandstone.

1.6 4201.2 4202.8 Medium sandstone with coarse sandstone grains, 1/4" green shale at 4201.5 becomes reddish toward base.

$2.2 \quad 4202.84205 .0 \quad$ Medium sandstone pale pink at top and more reddish downward. Sandstone planar bedded and rippled.

0.2 4205.0 4205.2 Dark green shale with sandstone blebs (burrows) and redbrown mudstone.

$12.6 \quad 4205.24217 .8 \quad$ Red stained, cross-bedded coarse sandstone. Local granule lag at 4214.4 . Swirly deformation at 4206.6 to 4210.5.

0.6 4217.8 4218.4 Medium sandstone - mottled pink and pale pink, crossbedded, sandstone with three inches thick dark green shale and brownish mudstone, bioturbated.

5.2 4218.4 4223.6 Cross-bedded, coarse sandstone with local granule laminations.

0.4 4223.6 4224.0 Laminated shale and mudstone, dark green and red brown.

$2.5 \quad 4224.04226 .5 \quad$ Reddish, coarse, horizontal thin bedded - rippled (?) sandstone.

Base of Core $-4226.5 \mathrm{ft}$ 
Appendix 2b Graphic Core Description, Peoples Gas, Light \& Coke, J. Williams \#4

Peoples Gas, J. Williams \#4

16, T21N, R7E, Champaign Co., Illinois

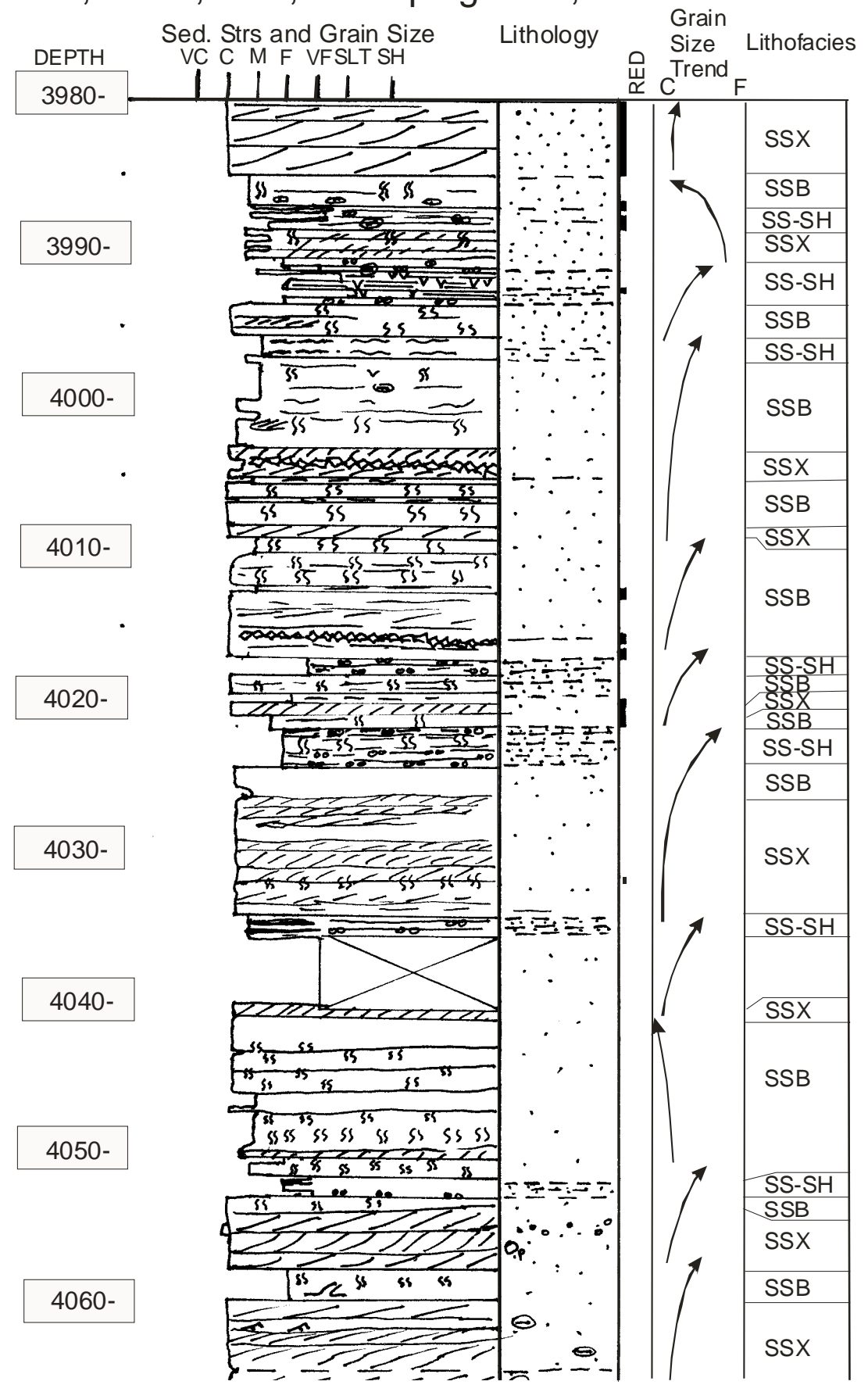




\section{Peoples Gas, J. Williams \#4}

16, T21N, R7E, Champaign Co., Illinois

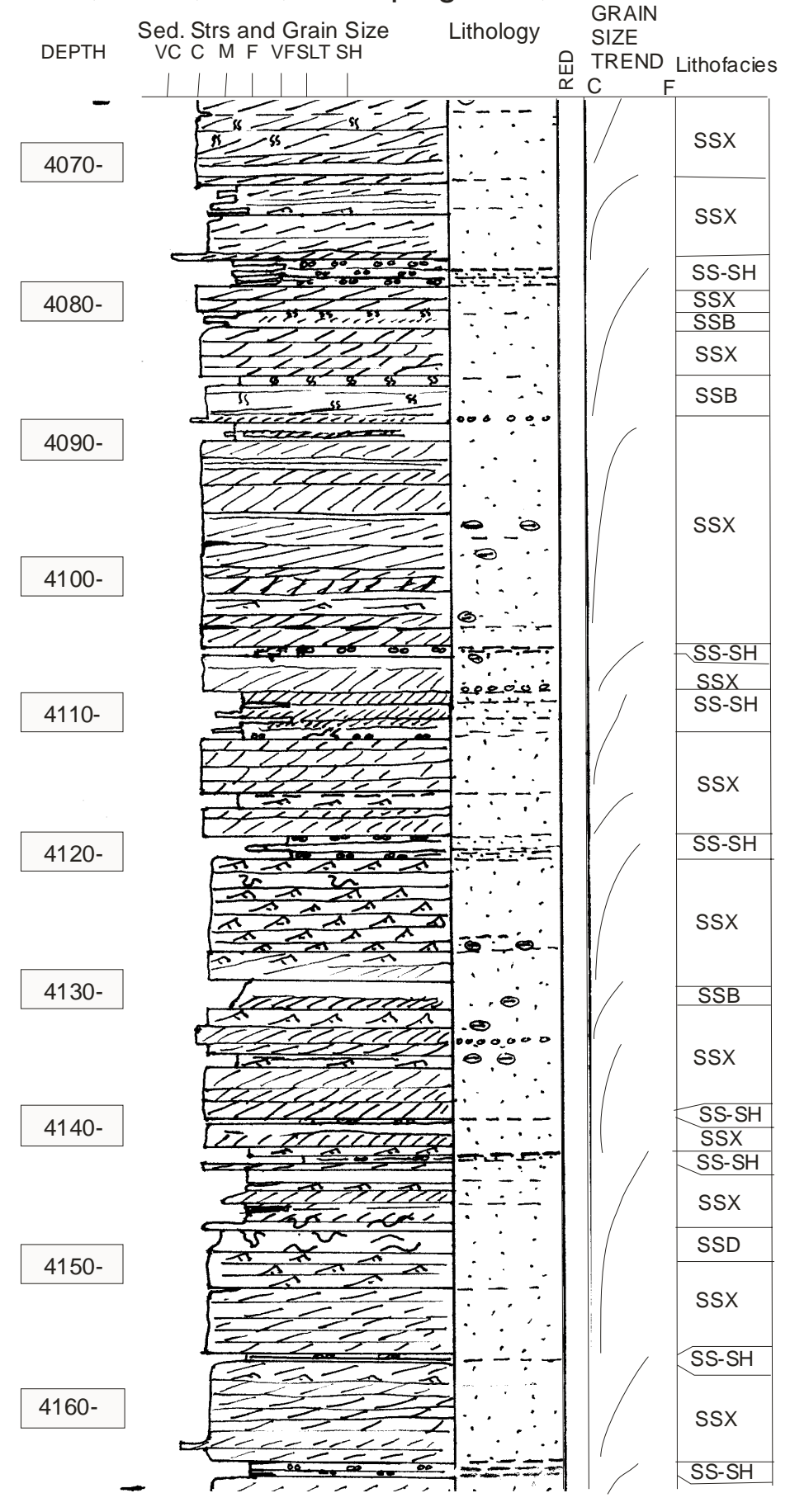




\section{Peoples Gas, J. Williams \#4}

\section{6, T21N, R7E, Champaign Co., Illinois}

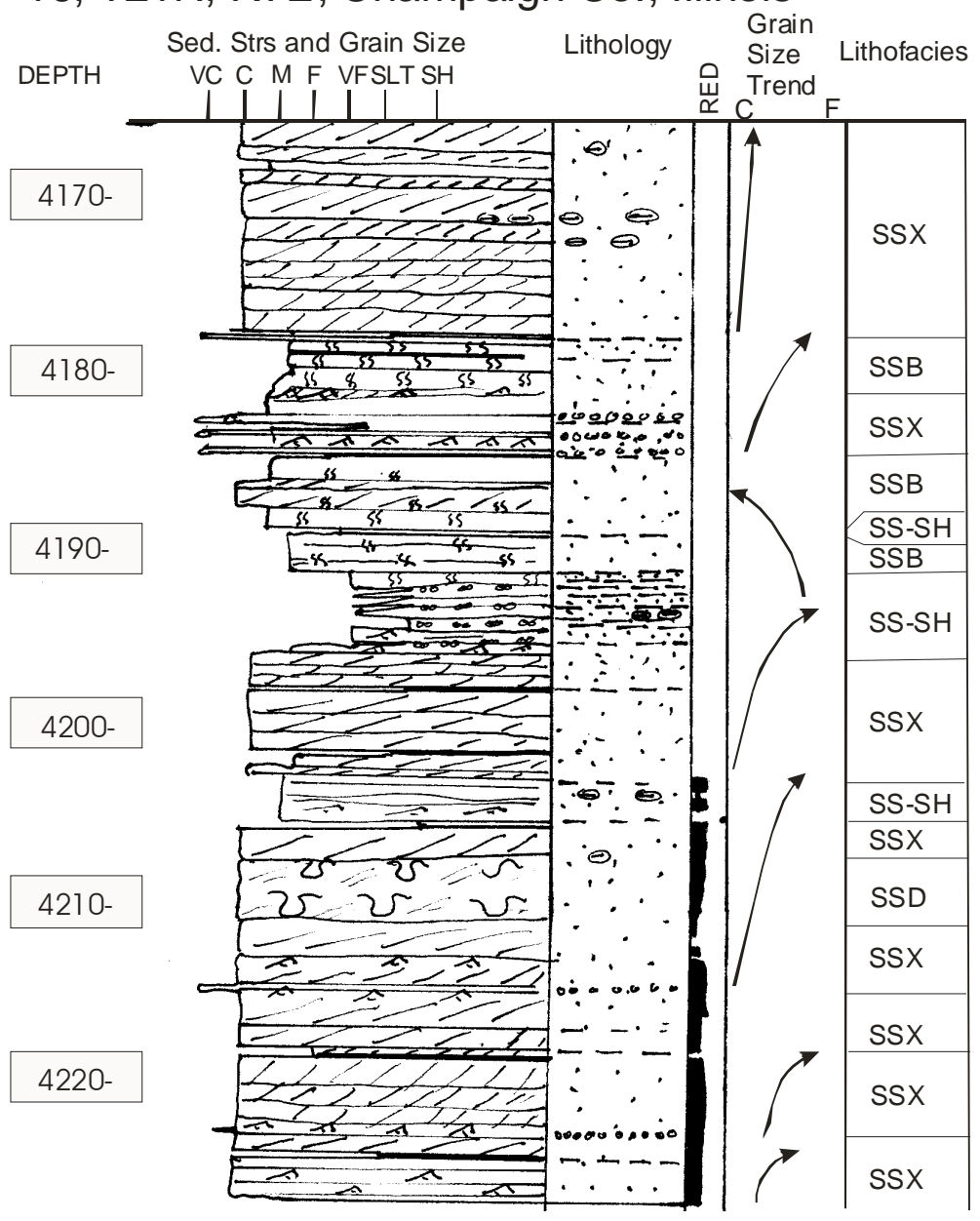

Rippled
Sudcracks

Legend

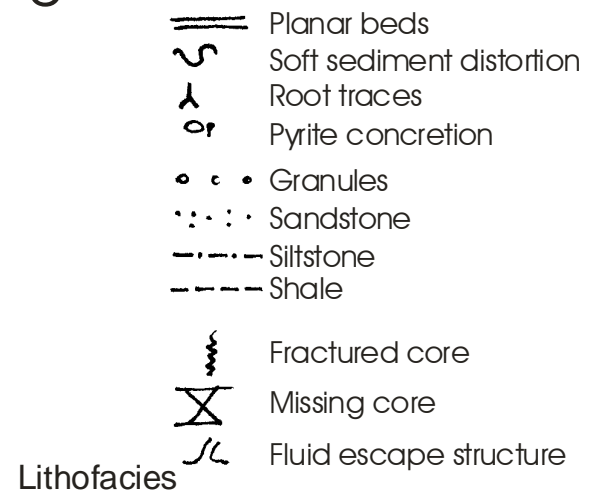

SSX Cross-bedded medium to coarse sandstone

SSB Bioturbated medium to coarse sandstone

SS-SH Interbedded very fine to medium sandstone and shale

SSD Soft Sediment deformed sandstone 


\section{Appendix 3a. Core Description - Peoples Gas, Light \& Coke, Hazen \#5 Well}

Sec. 27, T21N, R7E

Champaign County

Logged by David G. Morse, April 25, 2002

C-15056

TOP OF CORE $3985.0 \mathrm{ft}$

API \# 120192181400

\section{Thickness Top Bottom}

\section{MANLOVE FIELD}

\section{Mt. Simon Formation}

1.0 3985.03986 .0 Interbedded pinkish very fine sandstone with internal fine clay laminae and $1 / 4$ " diameter round horizontal burrows - and coarse to medium sandstone with Skolithos burrows.

4.8 $\quad 3986.03990 .8$ Interlaminated fine to very fine sandstone and dark gray to black shale. Finer laminated V-shaped sand filled mud cracks and horizontal round burrows. Some sands medium size; other bioturbation types here too. Wide grazing forms $3 / 4$ " high.

$2.0 \quad 3990.83992 .8$ Interbedded pinkish very fine sandstone and medium-coarse sandstone with inclined bedding, faintly bioturbated, traces of greenish gray shale bed remnants. Some fine black dots pyrite.

1.2 3992.83994 .0 Interbedded very fine pink sandstone and medium-coarse sandstone as above but with some fine gray shale, fine laminations.

1.5 $\quad 3994.03995 .5$ Finely interlaminated dark gray shale and very fine sandstone, round bioturbated burrows and v-shaped, sand filled mudcracks Shale very finely laminated - crudely rhythmic. 


\section{Thickness Top Bottom}

7.3 $\quad 3995.54002 .8$ Interbedded medium and coarse to very coarse sandstone with rare very thin red and dark gray shale drapes. Sandstone is horizontal to cross-bedded, locally light purple colored. Medium sandstone has vertical burrows (Skolithos).

0.2 4002.8 4003.0 Very dark gray siltstone - micaceous.

2.54003 .04005 .5 Interbedded medium-coarse sandstone, pale cream colored, unbedded with faint vertical burrows and a reddish and greenish highly bioturbated fine sandstone with silt. Vertical and round horizontal burrows.

0.6 4005.5 4006.1 Interlaminated very fine sandstone and gray claystone with sand filled burrows ( $1 / 4$ " circular) and large sandstone burrows.

1.9 4006.1 4008.0 Medium-coarse cream colored sandstone, local very coarse beds, weak horizontal bedding, some sandstone has dark gray hue (pyrite?) and rounded horizontal burrows and trace of greenish gray silt or clay.

0.5 4008.0 4008.5 Pinkish very fine sandstone with wispy shale laminations, mudcracks and bioturbation.

3.2 4008.54011 .7 Interbedded buff medium to coarse sandstone and fine to very fine sandstone - local bioturbation - round horizontal burrows " in diameter, faint cross-bedding, a few gray green mudchips on cross-beds.

$0.2 \quad 4011.74011 .9$ Interlaminated very fine sandstone and dark gray silt- or claystone. Round sand filled burrows and V-shaped cracks.

16.24011 .94028 .1 Interbedded fine, medium and coarse sandstone, cream/buff colored commonly with vertical burrows and local stylolitic intervals. Some weakly cross-bedded sandstone remains. One thin bed of very coarse sandstone was very pure, clean sandstone with quartz overgrowths - very porous.

0.4 4028.14028 .5 Interbedded dark gray silty claystone and very fine sandstone, round horizontal burrows.

3.7 4028.54032 .2 Mottled cream and pinkish bioturbated fair to medium-coarse sandstone - vertical burrows and local stylolites. Some floating very coarse sandstone grains. 


\section{Thickness Top Bottom}

1.6 4032.2 4033.8 Interlaminated dark gray clay/siltstone and very fine sandstone, small round horizontal burrows and larger grazing burrows.

0.6 4033.8 4034.4 Pinkish, mottled, vertical burrows, medium sandstone, poorly sorted.

2.6 4034.4 4037.0 Buff/cream medium, coarse, and very coarse cross-bedded sandstone.

4.0 4037.0 4041.0 Light maroon and buff coarse sandstone - horizontal and cross-bedded with vertical burrows locally and local shale interclasts.

1.8 4041.04042 .8 Pinkish-maroon medium sandstone and one thin red shale lamination, sandstone is cross-bedded.

0.4 4042.8 4043.2 Inter thin bedded green gray siltstone and fine sandstone bioturbated.

2.3 4043.2 4045.5 Greenish-gray medium sandstone and mottled buff and pinkish medium sandstone with greenish-gray sworls.

1.0 4045.5 4046.5 Mottled pinkish, buff and grey green medium-coarse sandstone.

2.5 4046.5 4049.0 Cross-bedded, medium-coarse, buff sandstone, fines upward, curved trough cross-sets.

2.8 4049.04051 .8 Poorly sorted, weakly bedded fair to medium pinkish-buff sandstone with wispy green stylolitic(?) Zones at 4049.2 and 4049.7 (may also be bioturbated?) Sandstone beds have faint vertical burrows.

1.9 4051.8 4053.7 Coarse to very coarse buff sandstone - cross-bedded and rippled.

0.5 $\quad 4053.74054 .2$ Fine sandstone with stylolitic shale whiskers bioturbated.

0.7 4054.24054 .9 Interlaminated black-gray silt and pinkish very fine sandstone, horizontal round, sand-filled burrows and wedge shaped Vcracks. 


\section{Thickness Top Bottom}

7.6 $\quad 4054.94062 .5$ Weakly bedded buff to medium sandstone with floating very coarse sand grains, locally stylolitic with gray green or black wispy residue. Vague mottling (bioturbation) 4060 to 4062.5. Pyrite patch 4061.2. Mudchips in basal three inches.

0.6 4062.5 4063.1 Coarse cross-bedded sandstone with some very coarse sandstone grains.

6.9 4063.1 4070.0 Mottled, interbedded medium and fine sandstone with both vertical and round horizontal burrows. Local stylolitic surface, and also a coarse sandstone thin bed.

1.9 4070.0 4071.9 Medium to coarse cross-bedded buff sandstone with local coarse lags at the base of sets. Mottling between 4071.571.7 .

1.1 4071.94073 .0 Interbedded fine to medium coarse sandstone. Mottled bedding within separate beds. Stylolitic surface with black silty whiskers at base.

5.4 4073.0 4078.4 Cross-bedded medium-coarse sandstone, buff colored, a few stylolitic boundaries.

1.6 4078.4 4080.0 Fine to very fine sandstone, pinkish with thin shaley interlaminated fine silt. Sands bioturbated $1 / 2$ " diameter to $1 / 16$ " diameter rounded sand-filled burrows.

0.9 4080.0 4080.9 Black-dark gray silt with very fine sand filled round burrows finely laminated silt with wiggly contacts.

2.3 4080.94083 .2 Fine to medium buff sandstone - bioturbated and crossbedded.

3.3 4083.2 4086.5 Medium to coarse cross-bedded sandstone.

$2.5 \quad 4086.54089 .0$ No sample.

3.7 $\quad 4089.04092 .7$ Medium to coarse cross-bedded sandstone.

0.8 4092.7 4093.5 Weakly interbedded fine and medium sandstone, buff, faint horizontal bedding.

$2.0 \quad 4093.54095 .5$ No sample. 


\section{Thickness Top Bottom}

1.4 4095.5 4096.9 Weakly interbedded fine and medium sandstone as above. Whole core analysis sample reference: \#114.

$2.1 \quad 4096.94099 .0$ No sample.

1.0 4099.04100 .0 Weakly interbedded fine and medium sandstone as above. \#115.

$0.7 \quad 4100.04100 .7$ Cross-bedded medium to coarse sandstone with granule floaters, buff. \#116.

2.3 4100.7 4103.0 Bioturbated fine to medium sandstone with coarse sandstone and granule floaters. Skolithos and local stylolites, two black shale partings.

1.0 4103.0 4104.0 Cross-bedded medium to coarse sandstone, buff, porous shale chips $(1 / 2$ "long) on cross-beds.

0.8 4104.0 4104.8 Bioturbated fine and medium to coarse sandstone interbeds. Skolithos.

14.5 4104.8 4119.3 Cross-bedded medium, coarse and very coarse sandstone, tabular foresets, porous, buff to very slight pink tinge in color. Grain size sorted along successive foreset laminations. 6" to 24 " set heights.

3.4 $\quad 4119.34122 .7$ No sample.

2.1 4122.74124 .8 Cross-bedded medium and coarse sandstone as above.

1.2 4124.8 4126.0 Fine to medium sandstone, structureless, with floating granules and one stylolite with black silt/shale at 4125.5 .

$1.4 \quad 4126.04127 .4$ Cross-bedded coarse to very coarse sandstone with some granules at base of cross-bedded set. Very sharp base over shale.

1.3 4127.4 4128.7 Dark gray to black laminated silt with fine sand filled cracks and burrows toward base.

$1.1 \quad 4128.74129 .8$ No sample.

0.2 4129.8 4130.0 Structureless sandstone, fine to medium grained with floating granules. \#145. 


\section{Thickness Top Bottom}

$2.0 \quad 4130.04132 .0$ No sample.

$0.5 \quad 4132.04132 .5$ Cross-bedded medium to coarse sandstone.

0.5 4132.5 4133.0 Fine to medium sandstone with possible flame structure with fine sandstone flowing up in to coarser sandstone.

$1.0 \quad 4133.04134 .0$ No sample.

$0.4 \quad 4134.04134 .4$ Cross-bedded medium sandstone. \#149.

$1.4 \quad 4134.44135 .8$ No sample.

0.7 4135.84136 .5 Cross-bedded medium to coarse sandstone. \#151.

3.7 $\quad 4136.54140 .2$ No sample.

7.8 4140.24148 .0 Cross-bedded medium to coarse sandstone. \#155 at top. \#162 at base. Very heterogeneous size grains on crossbedded sets. Well sorted within individual laminae.

3.3 4148.04151 .3 No sample.

5.9 4151.3 4157.2 Cross-bedded medium to coarse sandstone, sets up to three feet high; mostly medium sandstone, few very coarse grains, a few $1 / 2$ " long mud chips and granules at base.

1.0 4157.2 4158.2 Medium to fine sandstone with floating coarse sandstone grains and rare mud chips.

0.1 4158.2 4158.3 Finely interlaminated black siltstone and very fine buff sandstone that consists of burrow fills.

6.3 4158.3 4164.6 Cross-bedded buff to pinkish medium and coarse sandstone with local zones of stylolites and thin mud chip clasts.

3.4 4164.64168 .0 No sample.

6.3 4168.0 4174.3 Cross-bedded buff fine to medium sandstone as above.

$2.1 \quad 4174.34176 .4$ Fine pinkish-cream colored sandstone with stylolites and vertical burrows. 


\section{Thickness Top Bottom}

0.1 4176.4 4176.5 Interlaminated dark gray black siltstone and very fine sandstone, burrowed, wavy fine laminations.

1.3 4176.54177 .8 No sample.

0.2 4177.8 4178.0 Weakly cross-bedded medium sandstone with floating coarse sandstone grains.

0.4 4178.04178 .4 Laminated dark grayish black siltstone, micaceous.

0.3 4178.4 4178.7 Bioturbated very fine sandstone and dark gray black silt. Dense horizontal sand filled burrows. \#193.

4.0 $\quad 4178.74182 .7$ Interbedded and interlaminated medium, fine and very fine sandstone with finely laminated dark gray/black siltstone with sand filled horizontal burrows. (4180.2-4181.8 missing).

0.8 4182.74183 .5 Cross-bedded medium sandstone with fine to coarse sandstone grains.

$1.2 \quad 4183.54184 .7$ Missing.

0.3 4184.7 4185.0 Cross-bedded sandstone as above.

2.0 4185.0 4187.0 Very dark gray/black clayey siltstone, laminated with local pinkish very fine sandstone burrow fills, especially near top.

4.6 4187.0 4191.6 Medium sandstone with coarser interbeds, cross-bedded, local mud chips in cross-bedded sandstone. One inch interval at 4189.0 with thin green gray silty clay wisps. Some stylolites between 4189.0 and 4190.0 .

$4.4 \quad 4191.64196 .0$ Missing.

$2.8 \quad 4196.04198 .8$ Interbedded fine and medium sandstone with some coarser interbeds. Weakly cross-bedded and Skolithos.

2.7 4198.84201 .5 Fine to medium cross-bedded and weak horizontally bedded sandstone, one inch zone with shaley interclasts - flakes at 4200.8. Skolithos at 4200.0.

Base of core $-4201.5 \mathrm{ft}$ 


\section{Appendix 3b. Core Description - Peoples Gas, Light \& Coke, Hazen \#5 Well}

Peoples Gas, Hazen \#5

27, T21N, R7E, Champaign Co., Illinois

Mt. Simon Sandstone Core Description

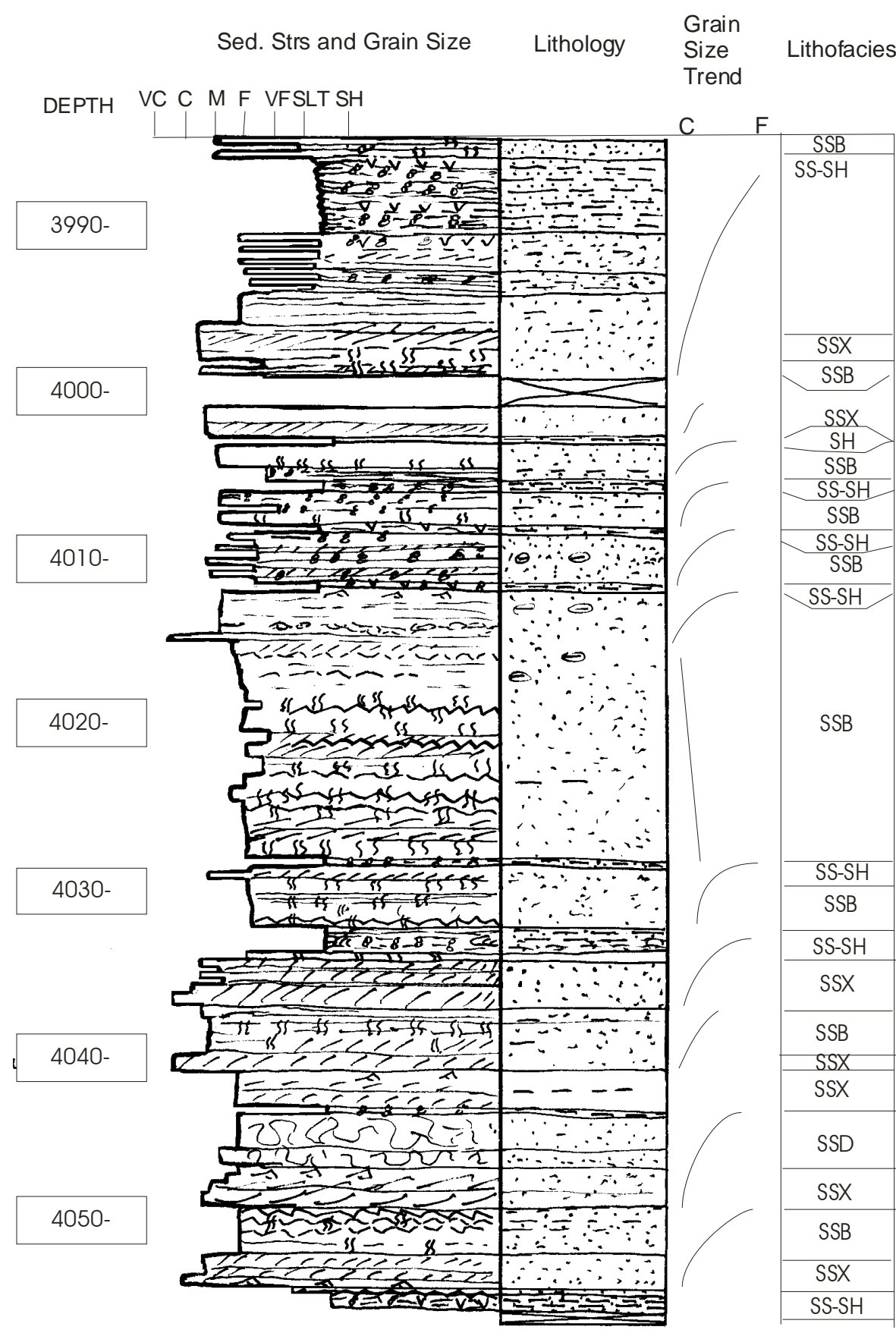


Peoples Gas, Hazen \#5

27, T21N, R7E, Champaign Co., Illinois

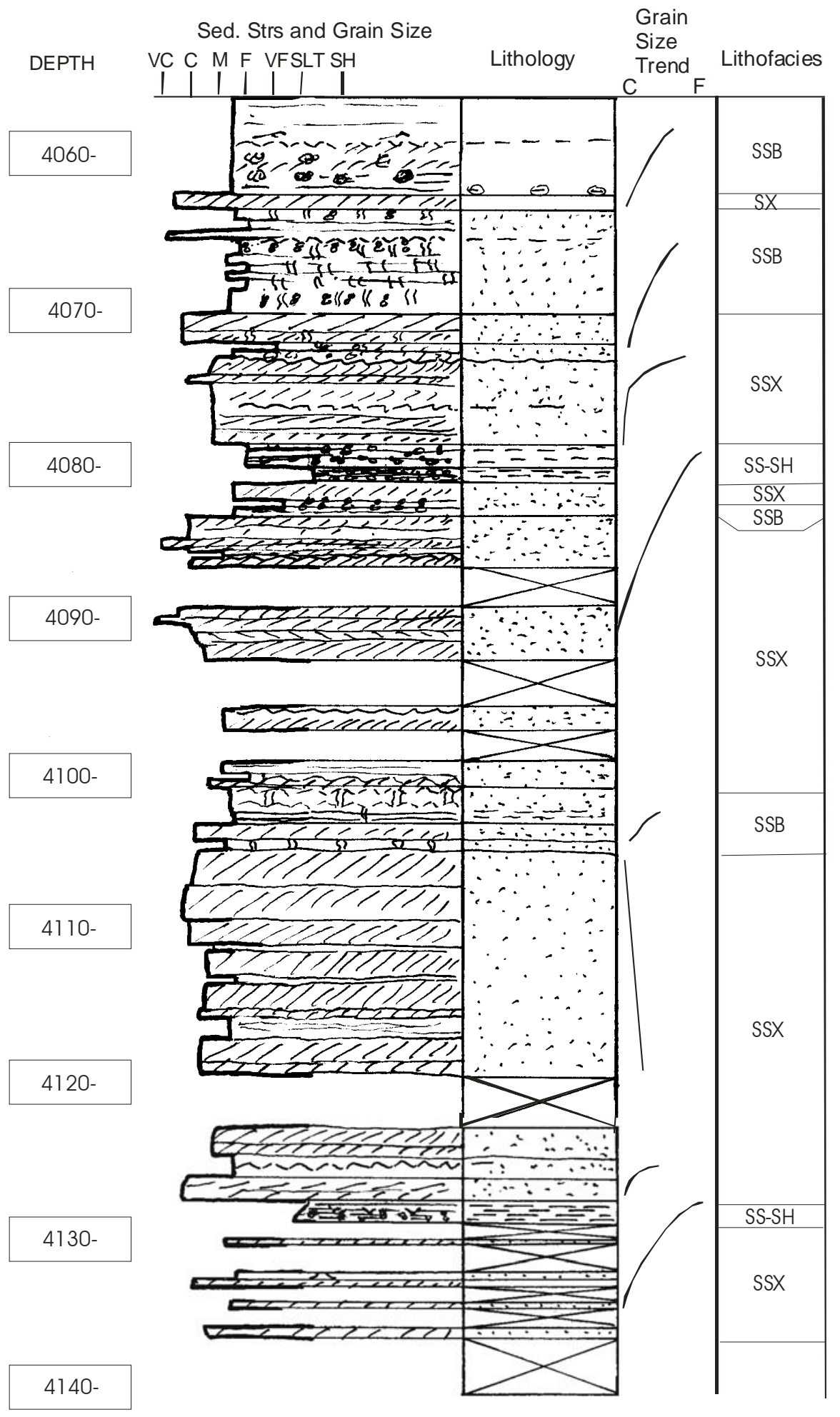




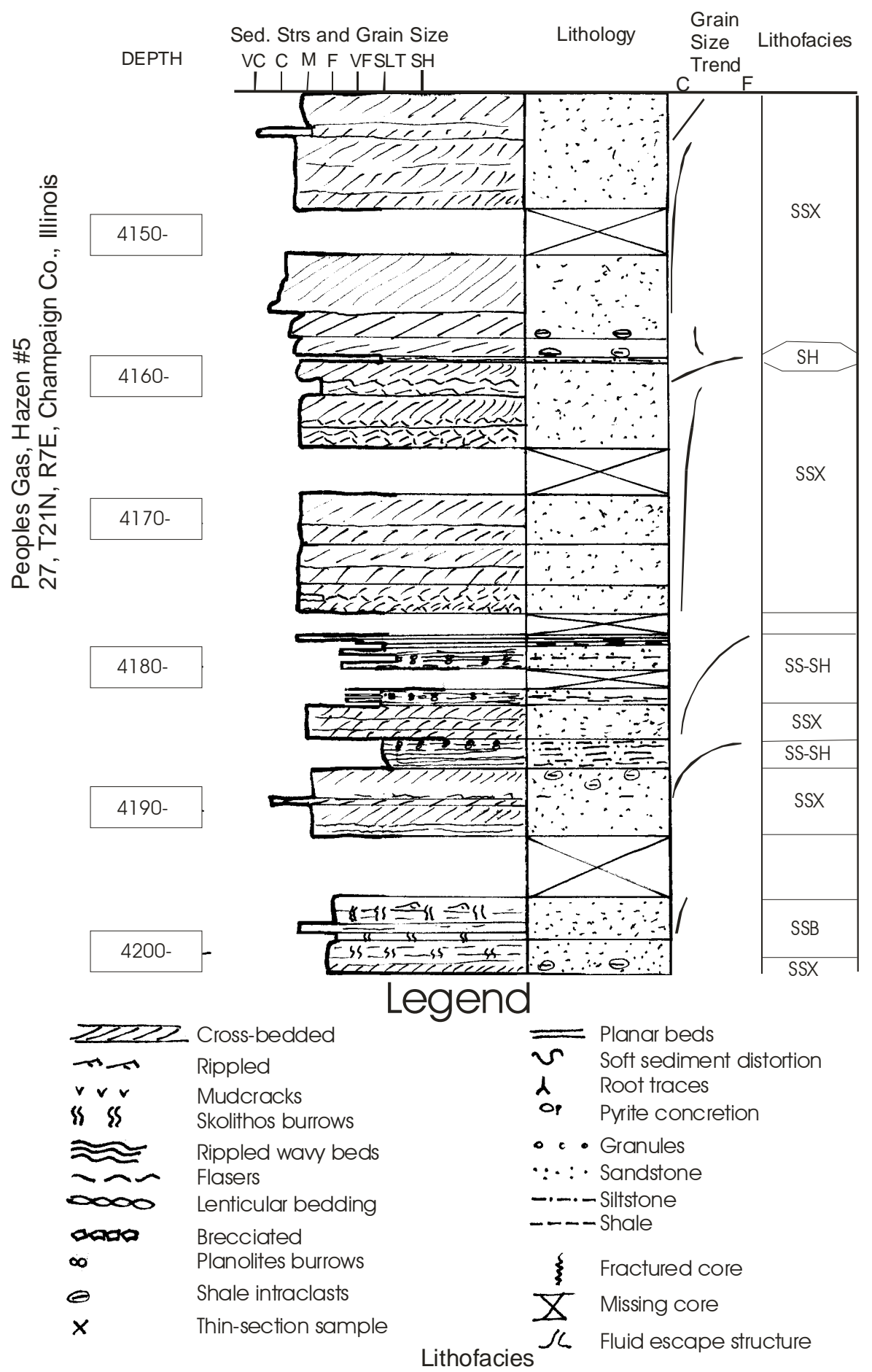

SSX Cross-bedded medium to coarse sandstone

SSB Bioturbated medium to coarse sandstone

SS-SH Interbedded very fine to medium sandstone and shale

SSD Soft Sediment deformed sandstone

$\mathrm{SH}$ Shale 


\section{Appendix 4. Northern Illinois Upper Mt. Simon Sandstone Water Salinity Data}

\begin{tabular}{|c|c|c|c|c|c|c|c|c|}
\hline API & Company & $\begin{array}{l}\text { Farm Name } \\
\text { Illinois Beach State }\end{array}$ & Farm \# & $\mathrm{sec}$ & $\mathrm{T}$ & $\mathrm{R}$ & $\begin{array}{l}\text { TDS } \\
(\mathrm{mg} / \mathrm{l})\end{array}$ & $\begin{array}{l}\mathrm{Cl} \\
(\mathrm{mg} / \mathrm{l})\end{array}$ \\
\hline 120973414200 & USGS & $\begin{array}{l}\text { Park } \\
\text { Illinois Beach State }\end{array}$ & $\begin{array}{r}1 \\
\text { LKE 46N12E- }\end{array}$ & 14 & $46 \mathrm{~N}$ & $12 \mathrm{E}$ & 2570 & 370 \\
\hline 120973414200 & USGS & Park & $\begin{array}{r}14.6 \mathrm{~g} \\
\text { JDV } 28 \mathrm{~N} 1 \mathrm{~W}-\end{array}$ & 14 & $46 \mathrm{~N}$ & $12 \mathrm{E}$ & 1600 & 140 \\
\hline 120850034700 & Varner Well Drlg. & Galena & $24.2 b$ & 24 & $28 \mathrm{~N}$ & $1 \mathrm{~W}$ & 235 & \\
\hline 120430101300 & American Potash \& Chemi & cal Waste Disposal & \#1 & 9 & $39 N$ & $9 \mathrm{E}$ & 620 & \\
\hline 120910040000 & Hughes Oil Co. & Parish & $\# 1$ & 24 & $31 N$ & $13 \mathrm{E}$ & 38655 & 23224 \\
\hline 120070034300 & - & Belvediere & \#2 & 25 & $44 N$ & $3 E$ & 684 & \\
\hline 120070029200 & Co. & Belvediere & \#3 & 25 & $44 N$ & $3 E$ & 738 & \\
\hline 120150000200 & MileagerWerll Co. & Mt Carroll & \#3 & 2 & $23 N$ & $5 E$ & 376 & \\
\hline 120310384500 & S.B. Geiger & Mt. Prospect Village & \#5 & 34 & $42 \mathrm{~N}$ & $11 \mathrm{E}$ & 453 & \\
\hline 120850041300 & C.W. Varner & East Dubuque & $\# 1$ & 20 & $29 N$ & $2 W$ & 272 & \\
\hline 120890066600 & $\begin{array}{l}\text { Layne-Western Co. } \\
\text { J.P.Miller Artesian Well }\end{array}$ & Aurora & $\# 12 \mathrm{a}$ & 15 & $38 N$ & $8 \mathrm{E}$ & 780 & \\
\hline 120890060500 & Co. & $\begin{array}{l}\text { Batavia } \\
\text { City of Elgin-Schuler }\end{array}$ & \#3 & 22 & $39 N$ & $8 \mathrm{E}$ & 459 & \\
\hline 120890078200 & C.W. Varner & St & \#5 & 14 & $41 \mathrm{~N}$ & $8 \mathrm{E}$ & 395 & \\
\hline 120970237200 & Cliff Neely & Lake Bluff Village & \#3 & 20 & $44 N$ & $12 \mathrm{E}$ & 510 & \\
\hline 121110078200 & W.L. Thorre \& Co. & Crystal Lake Village & \#2 & 5 & $43 N$ & $8 \mathrm{E}$ & 280 & \\
\hline 121410068400 & J.B. Miller Well Co. & Polo City & $\# 1$ & 9 & $23 N$ & $8 \mathrm{E}$ & 337 & \\
\hline 122010030400 & Varner Well Drlg. & Rockford City & Unit \#4 & 34 & $44 N$ & $1 \mathrm{E}$ & 624 & \\
\hline 121550010400 & Jones \& Laughlin Steel & Waste Disposal Well & $\# 1$ & 3 & $32 \mathrm{~N}$ & $2 \mathrm{~W}$ & 60000 & \\
\hline 120910015100 & NGPLA & Knittel & M3 & 32 & $30 N$ & $10 \mathrm{E}$ & 17707 & 10000 \\
\hline 120910014700 & Natural Gas Storage Co. & Kilpatrick & M1 & 29 & $30 N$ & $10 \mathrm{E}$ & 16440 & 9500 \\
\hline 120910007300 & NGPLA & Schwark & M1 & 32 & $30 N$ & $10 \mathrm{E}$ & 17313 & 12000 \\
\hline 120910007600 & NGPLA & Bartlett & M1 & 33 & $30 N$ & $10 \mathrm{E}$ & 17402 & 10500 \\
\hline 120910009700 & NGPLA & Knittel & M1 & 32 & $30 N$ & $10 \mathrm{E}$ & 17201 & 11000 \\
\hline 120410079900 & OhioOil Co. & Shaw & 1 & 36 & $16 N$ & $8 \mathrm{E}$ & 102700 & 60997 \\
\hline 121970127400 & M.L. Livengood & Herrin & 1 & 23 & $36 N$ & $9 \mathrm{E}$ & 1210 & 400 \\
\hline 121090071600 & CIPS & Silas Hainline & S-34 & 31 & $7 \mathrm{~N}$ & $3 W$ & 22710 & 10650 \\
\hline 121090071700 & CIPS & $\begin{array}{l}\text { Proctor Endowment } \\
\text { J.C. Proctor }\end{array}$ & SM-3 & 20 & $7 \mathrm{~N}$ & $3 \mathrm{~W}$ & 20039 & 12400 \\
\hline 121090076500 & CIPS & Endowment & SM-5 & 20 & $7 N$ & $3 \mathrm{~W}$ & 18978 & \\
\hline 120310242200 & Western Springs City & City & 1 & $6.3 a$ & $38 N$ & $12 \mathrm{E}$ & 932 & \\
\hline 120192171400 & Peoples Gas \& Coke & O.Bidner & 2 & 15 & $21 \mathrm{~N}$ & $7 \mathrm{E}$ & 83600 & 48750 \\
\hline 120192197200 & Peoples Gas \& Coke & V. Sloan & 1 & 5 & $21 \mathrm{~N}$ & $7 \mathrm{E}$ & 82700 & 47700 \\
\hline 120190075200 & Peoples Gas \& Coke & F. Hazen & 1 & 20 & $21 \mathrm{~N}$ & $7 \mathrm{E}$ & 83700 & 49200 \\
\hline 120192254700 & Peoples Gas \& Coke & Kamerer & 3 & 26 & $21 \mathrm{~N}$ & $7 \mathrm{E}$ & 85500 & 49985 \\
\hline 120190133700 & Peoples Gas \& Coke & W. Leischner & 3 & 10 & $21 \mathrm{~N}$ & $7 \mathrm{E}$ & 90400 & 52400 \\
\hline 121130071700 & Nigas & Bates & 2 & 2 & $24 N$ & $2 \mathrm{E}$ & 77450 & 44000 \\
\hline 121130071900 & Nigas & Hoopers & 1 & 7 & $24 N$ & $3 E$ & 76200 & 43600 \\
\hline 121130065600 & Nigas & Grimes & 1 & 1 & $24 N$ & $2 \mathrm{E}$ & 77450 & 43000 \\
\hline 121130061600 & Nigas & Carden & 1 & 15 & $24 N$ & $2 \mathrm{E}$ & 81650 & 45100 \\
\hline 121130074200 & Nigas & Pyne & 1 & 14 & $25 N$ & $3 E$ & 67790 & 40750 \\
\hline 121130074100 & Nigas & E.W.Cooke & 1 & 14 & $25 N$ & $3 E$ & 65460 & 39250 \\
\hline 121130074300 & Nigas & Cooke & 3 & 14 & $25 N$ & $3 E$ & 66000 & 40000 \\
\hline 121130052800 & Nigas & J. Anderson & 1 & 31 & $26 N$ & $3 E$ & 59650 & 36600 \\
\hline 121130056200 & Nigas & Furrow & 2 & 31 & $26 N$ & $3 E$ & 59750 & 34500 \\
\hline 121130056200 & Nigas & Furrow & 2 & 31 & $26 N$ & $3 E$ & 59920 & 34250 \\
\hline 121050026600 & Nigas & Fordyce & 1 & 33 & $30 N$ & $3 E$ & 17901 & 10200 \\
\hline 121050027200 & Nigas & Fehr & 1 & 27 & $30 N$ & $3 E$ & 25800 & 11230 \\
\hline 121050027600 & Nigas & Fordyce & 4 & 33 & $30 N$ & $3 \mathrm{E}$ & 21400 & 10290 \\
\hline
\end{tabular}




$\begin{array}{ll}\text { API } & \text { Company } \\ 121050027600 & \text { Nigas } \\ 120712035100 & \text { Nigas } \\ 120712036800 & \text { Nigas } \\ 120710031400 & \text { Nigas } \\ 120712034900 & \text { Nigas } \\ 120710031700 & \text { Nigas } \\ 121050074100 & \text { Nigas } \\ 121050078300 & \text { Nigas } \\ 121050074200 & \text { Nigas } \\ 121050074000 & \text { Nigas } \\ 121050078900 & \text { Nigas }\end{array}$

Farm Name
Fordyce
J. Brook
Heap
L. Oliver
L. Oliver
Lillard
Feinhold
Clevenger
Dodson
Mackinson
Feinhold

\begin{tabular}{|c|c|c|c|c|c|}
\hline Farm \# & sec & $\mathrm{T}$ & $\mathrm{R}$ & $\begin{array}{l}\text { TDS } \\
(\mathrm{mg} / \mathrm{l})\end{array}$ & $\begin{array}{l}\mathrm{Cl} \\
(\mathrm{mg} / \mathrm{l})\end{array}$ \\
\hline 4 & 33 & $30 N$ & $3 E$ & 19804 & 10300 \\
\hline 1 & 18 & $9 \mathrm{~N}$ & $4 W$ & 14620 & 5600 \\
\hline 1 & 16 & $9 \mathrm{~N}$ & $4 W$ & 14275 & 5400 \\
\hline 1 & 7 & $9 N$ & $4 W$ & 12950 & 5300 \\
\hline 3 & 7 & $9 N$ & $4 W$ & 18180 & 5250 \\
\hline 1 & 14 & $9 N$ & $5 W$ & 14790 & 5200 \\
\hline 2 & 22 & $28 \mathrm{~N}$ & $6 \mathrm{E}$ & 51700 & 31000 \\
\hline 1 & 17 & $28 \mathrm{~N}$ & $6 \mathrm{E}$ & 40700 & 23500 \\
\hline 1 & 5 & $27 N$ & $6 \mathrm{E}$ & 53300 & 29500 \\
\hline 1 & 22 & $28 \mathrm{~N}$ & $6 \mathrm{E}$ & 50200 & 29000 \\
\hline 5 & 33 & $28 \mathrm{~N}$ & $6 \mathrm{E}$ & 47100 & 28900 \\
\hline
\end{tabular}




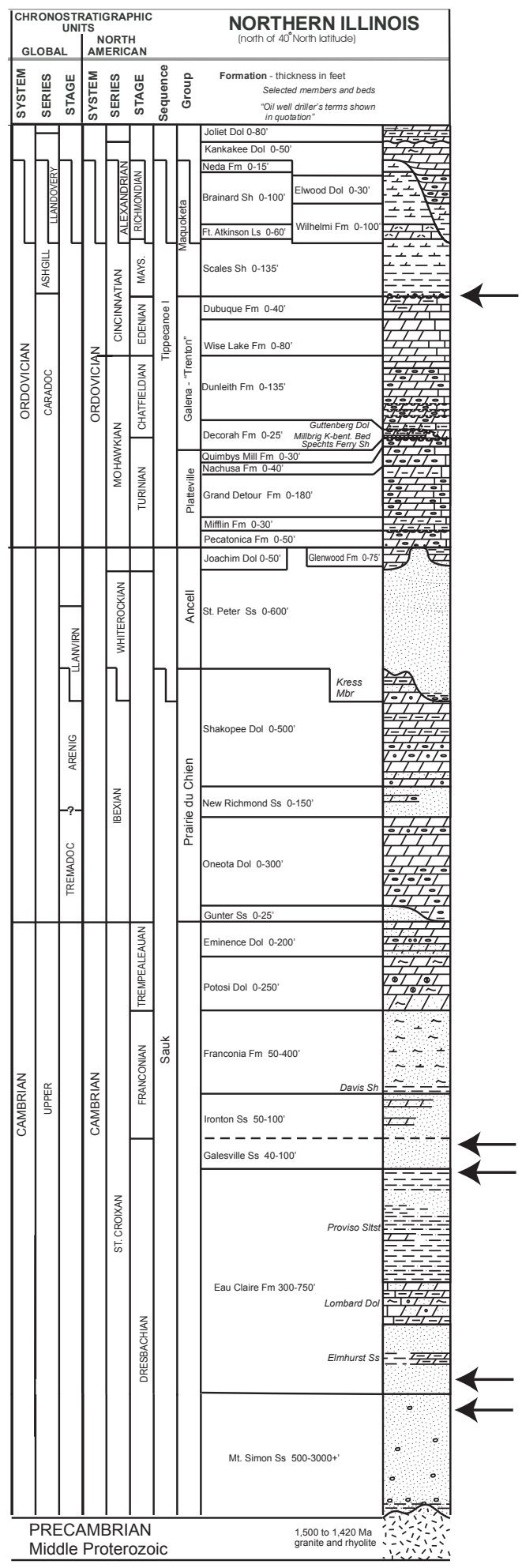

Fig. 1 


\section{Cambrian Correlation Chart}

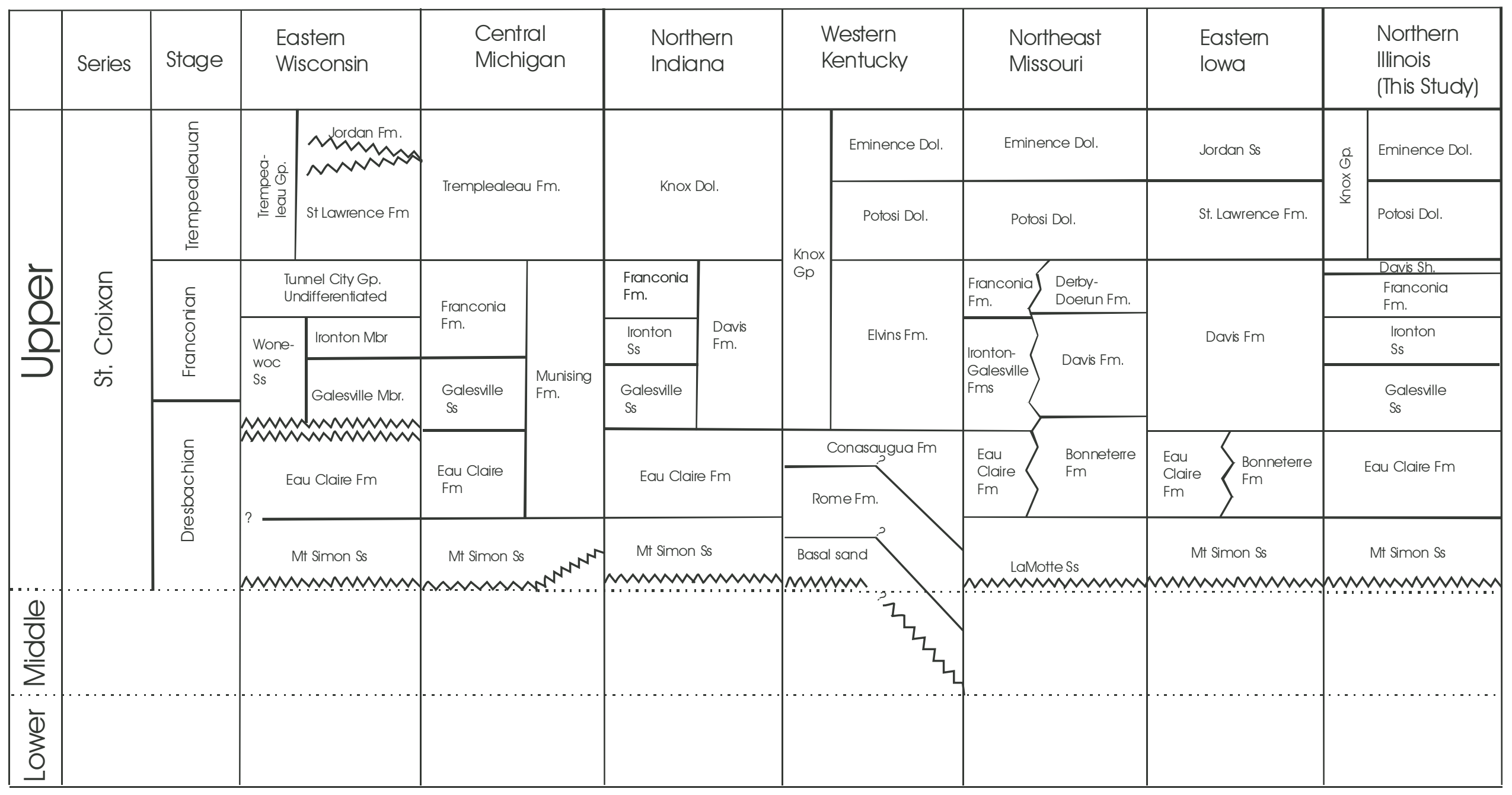

(From Shaver, 1985, and Adler, 1987)

Figure 2 


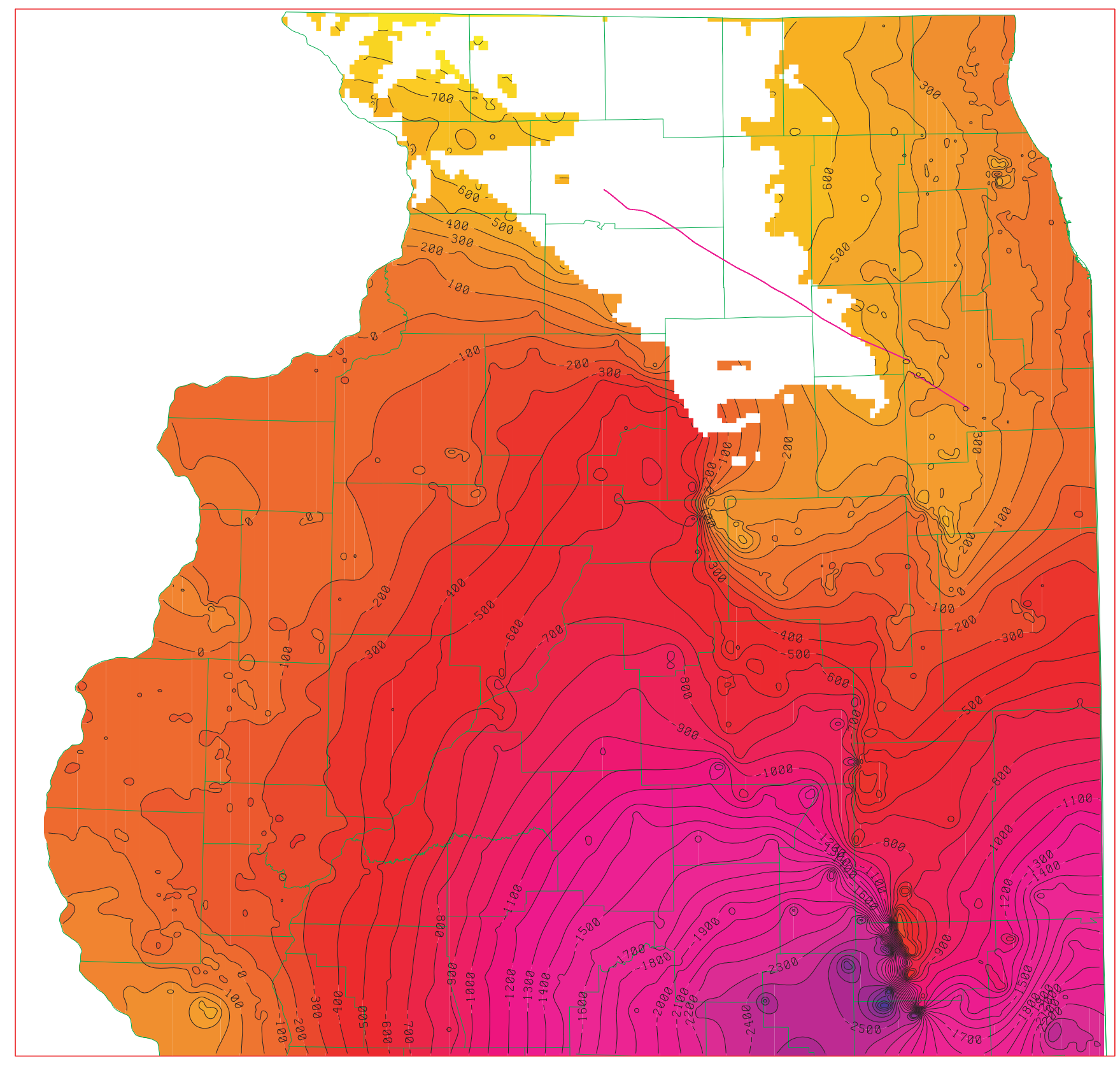

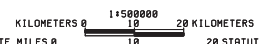

STATUTE MLLES 0 29 STATUTE MLLES

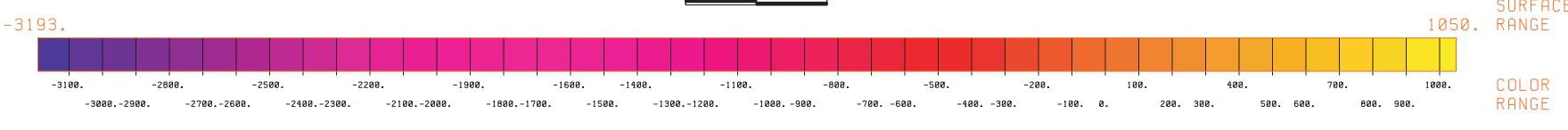

Figure 12 Top Galena 


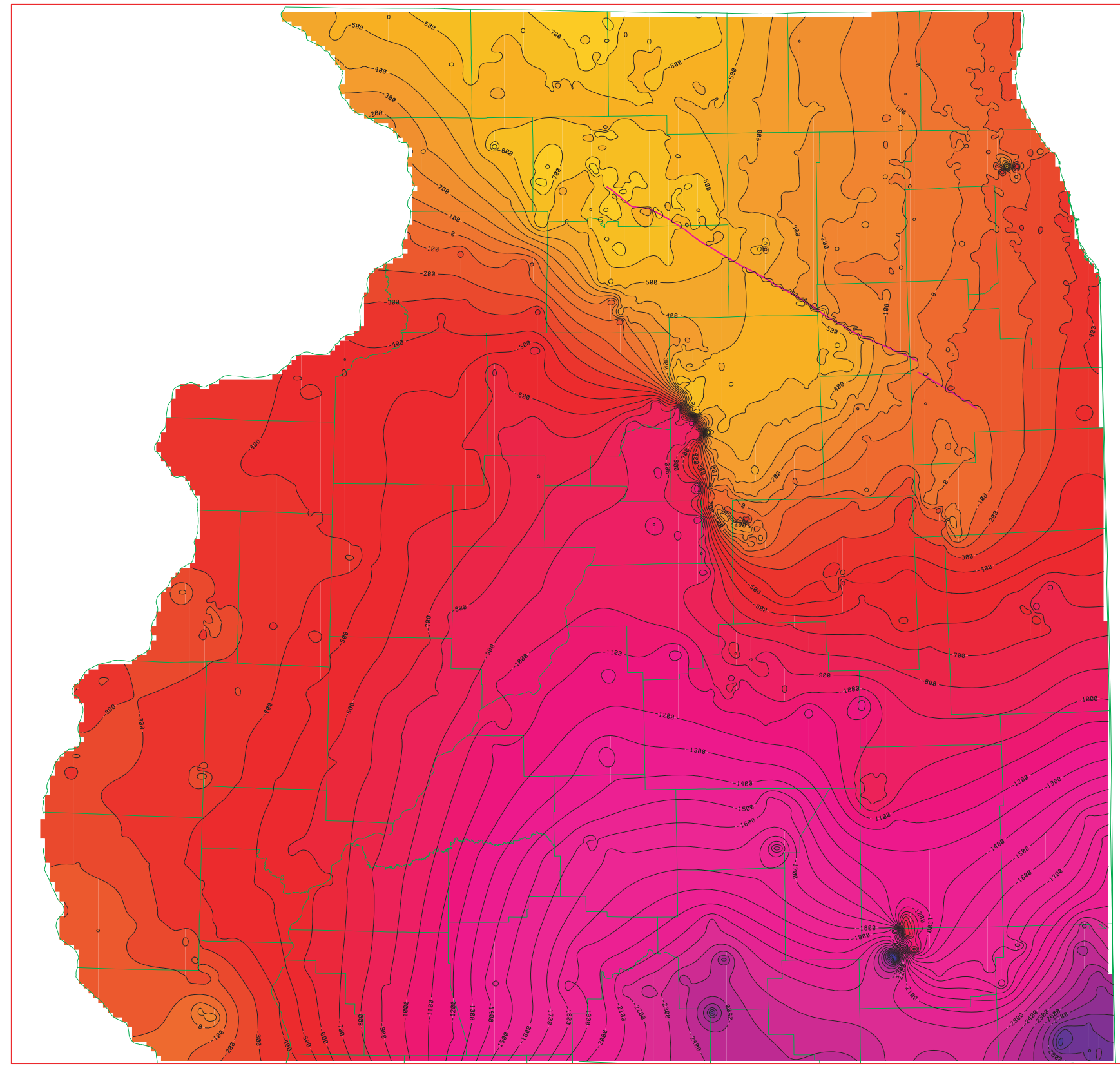

KILOMETERS O 18 20 KILONETERS

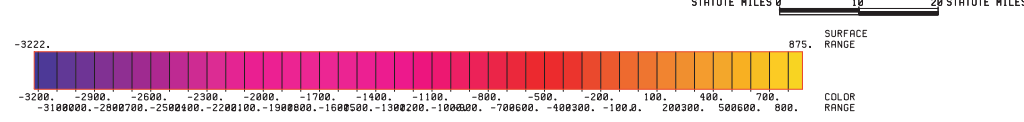

\section{Top of St. Peter Sandstone}

Figure 4 


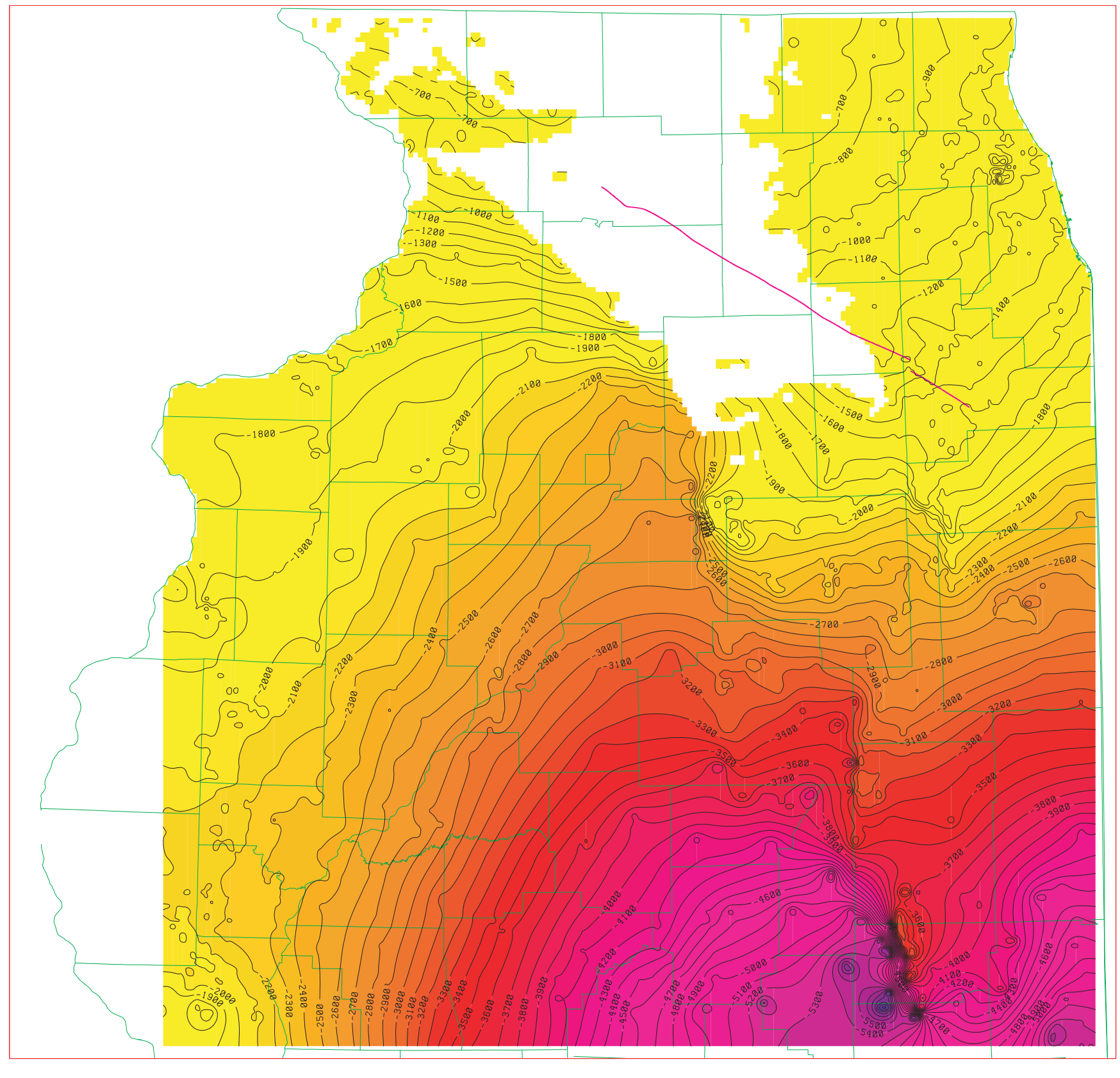

Statute MILLES

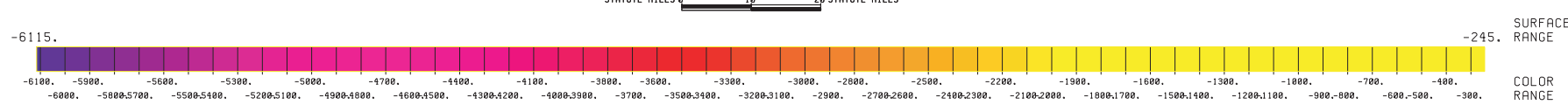

Top Mt. Simon S ands tone

Figure 5 


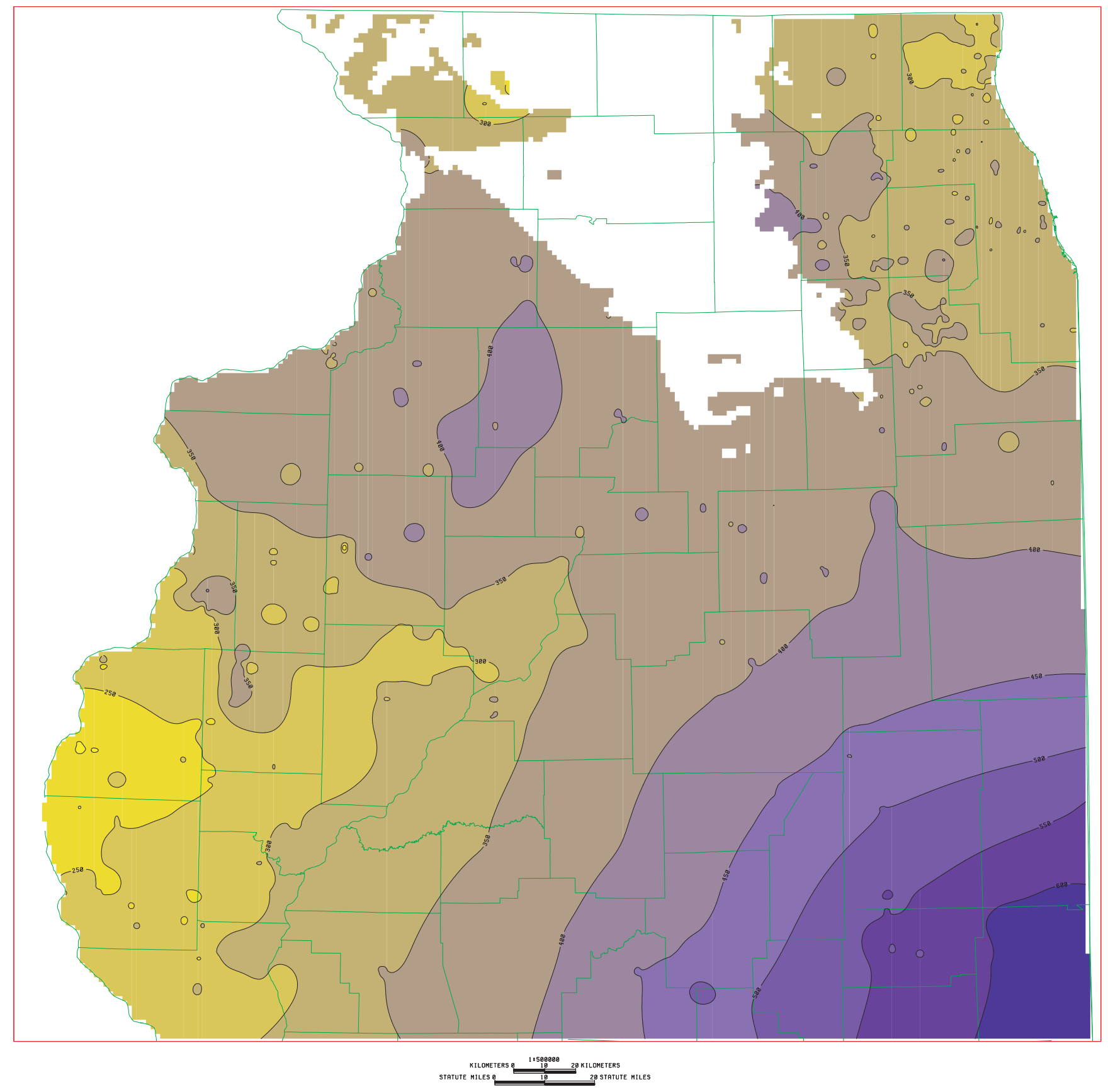

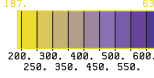

Figure 6. Galena to St. Peter Isopach 

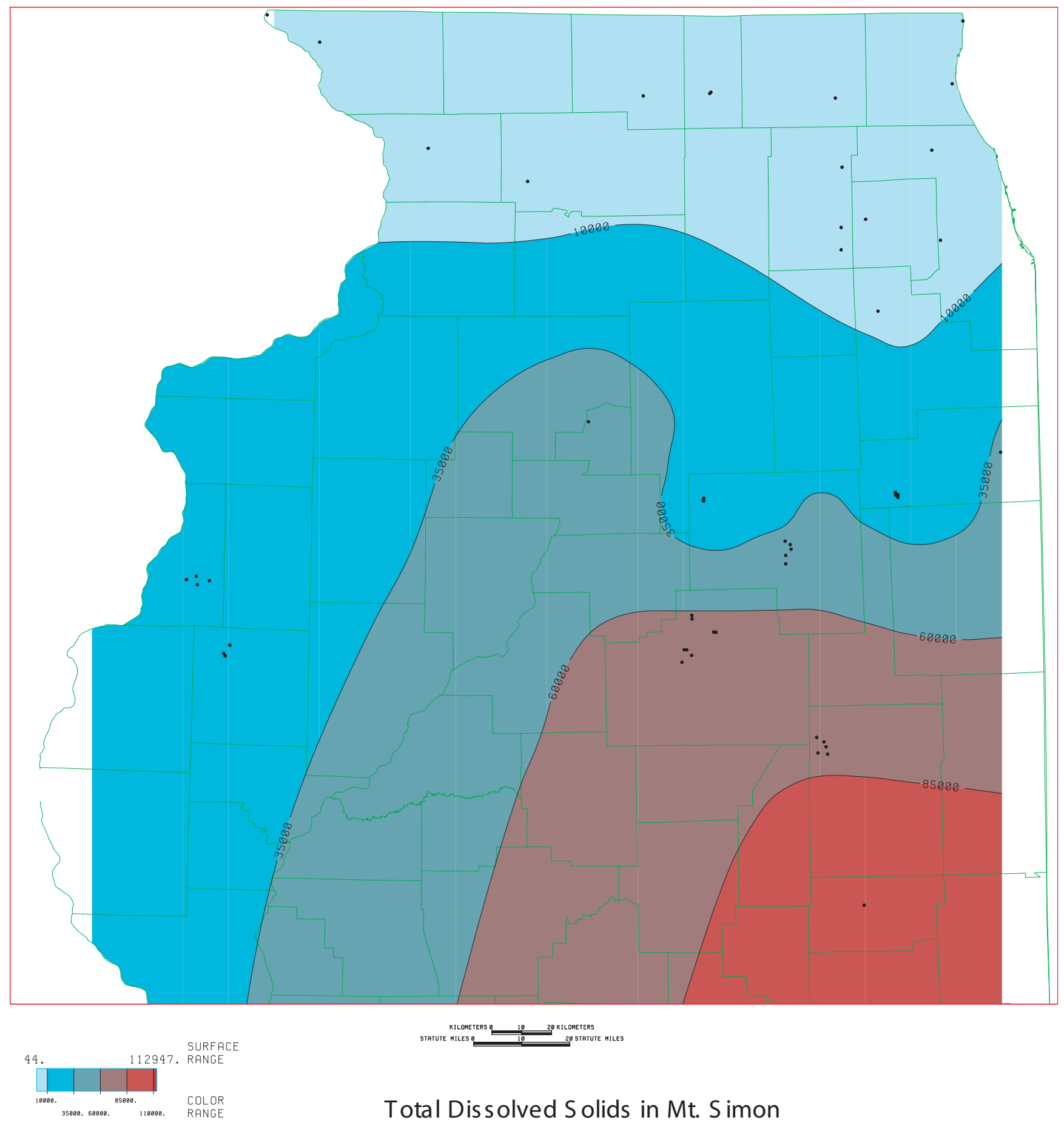

Total Dis solved Solids in Mt. Simon

Figure 7 


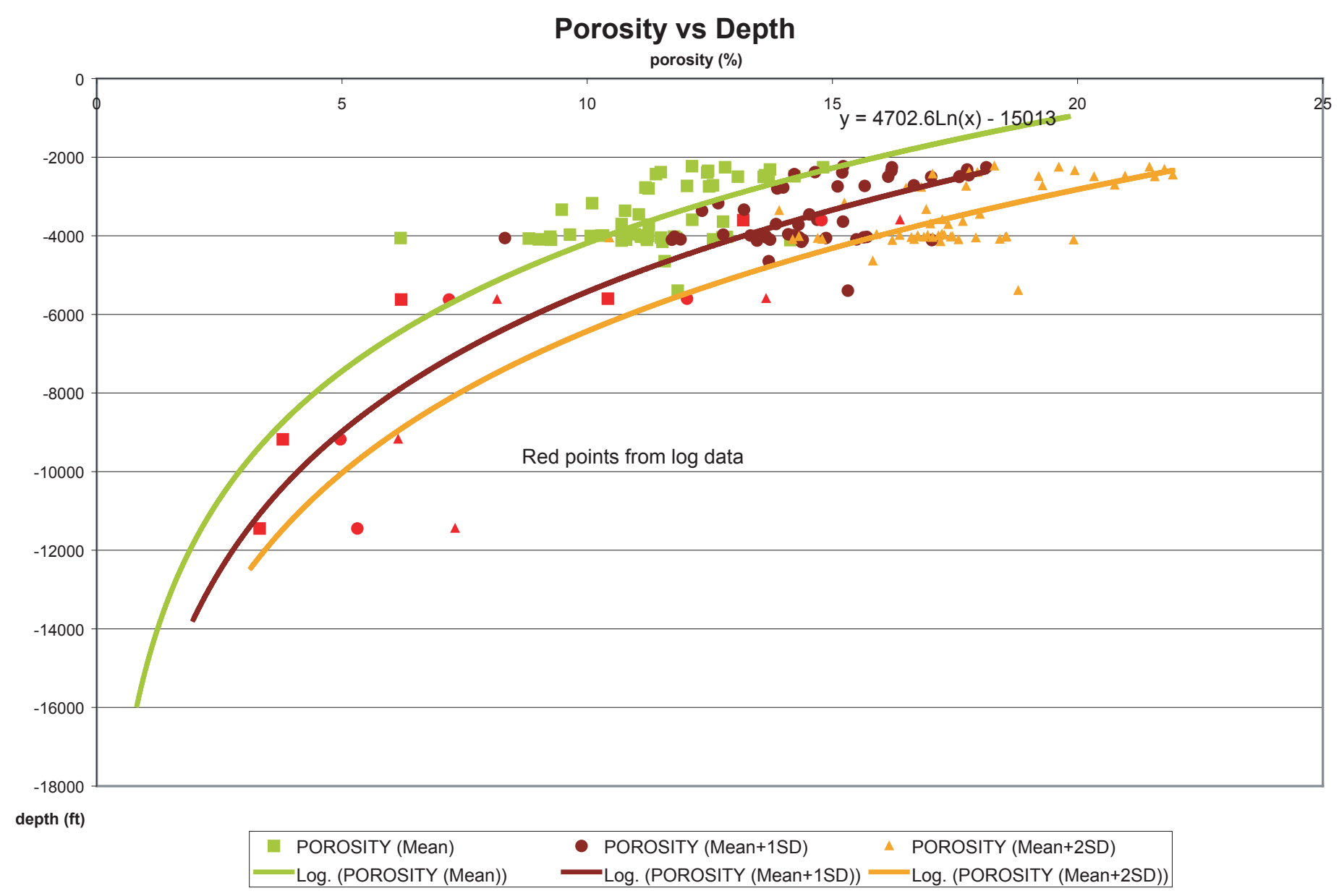

Figure 8 


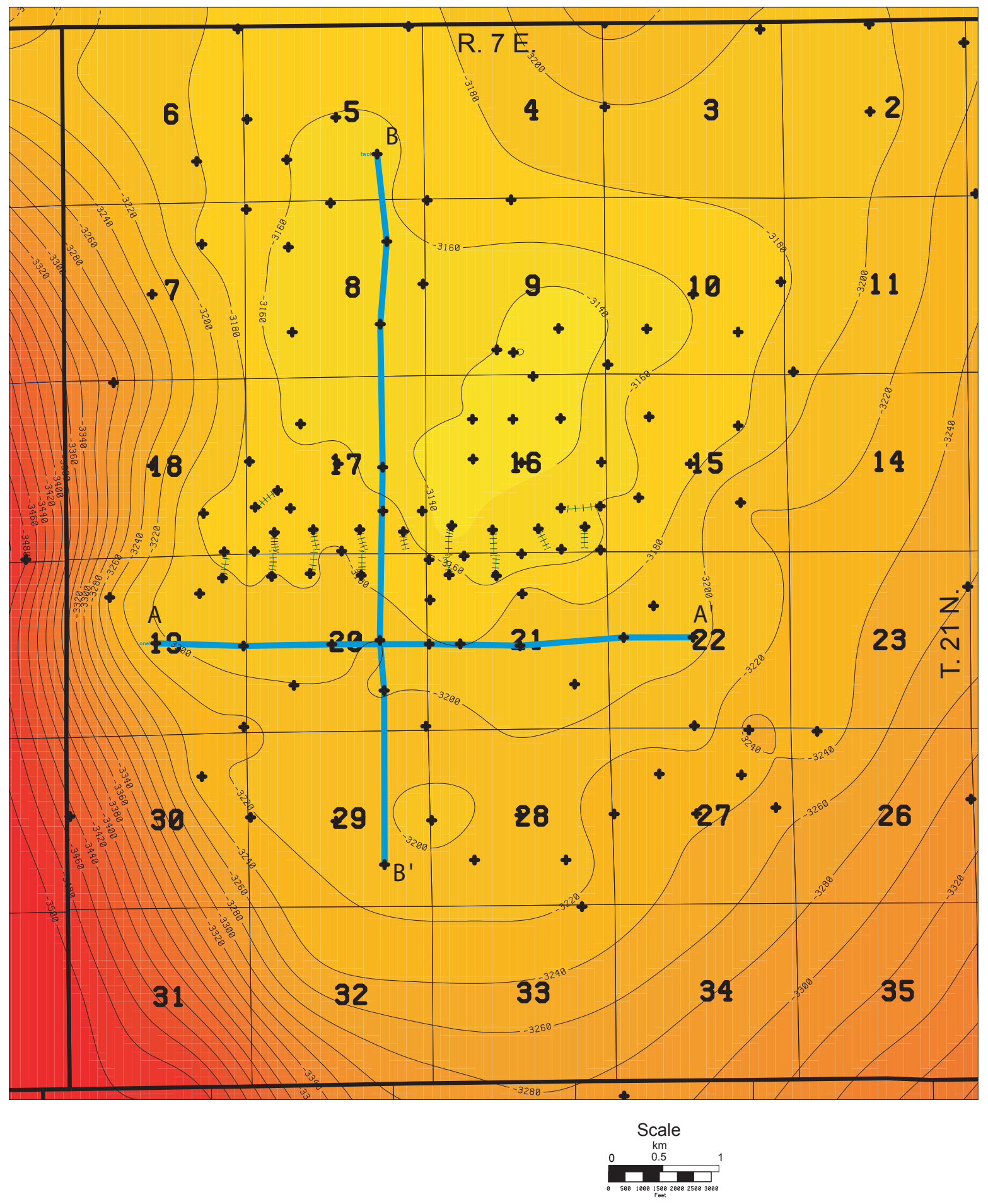

Figure 9 


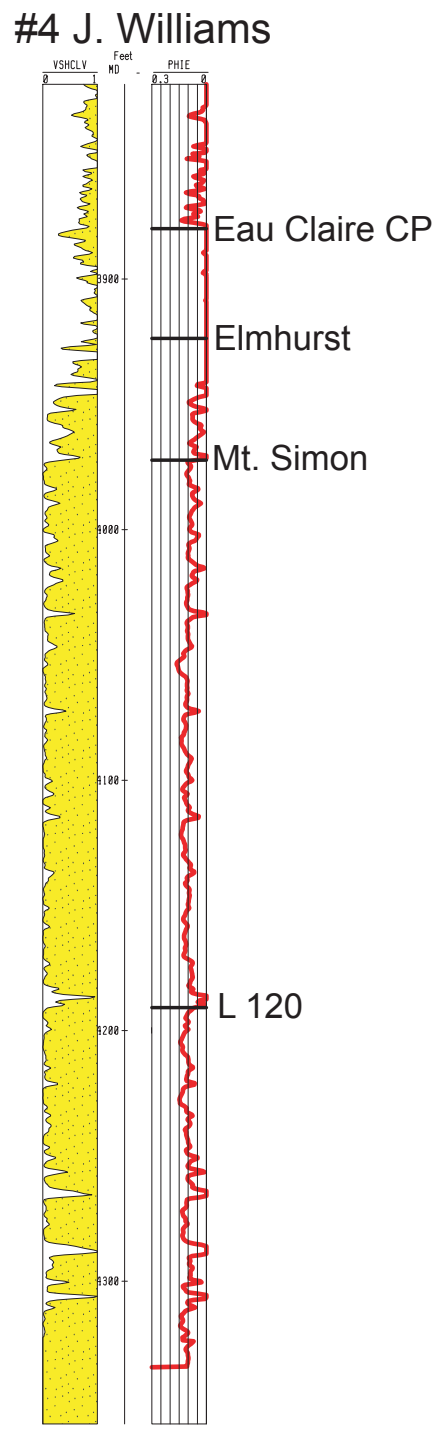

Figure 10 
West

East

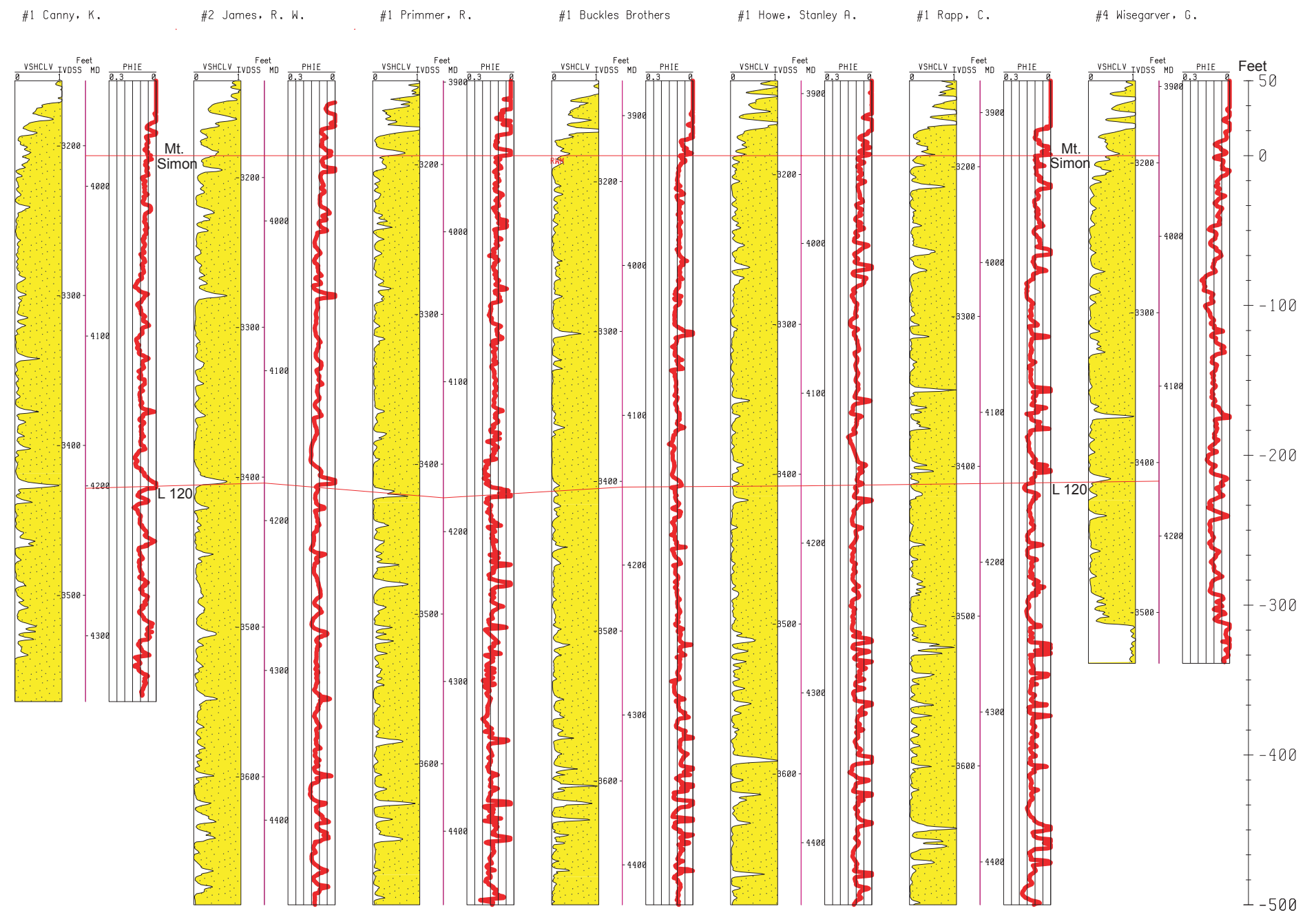

Figure 11 


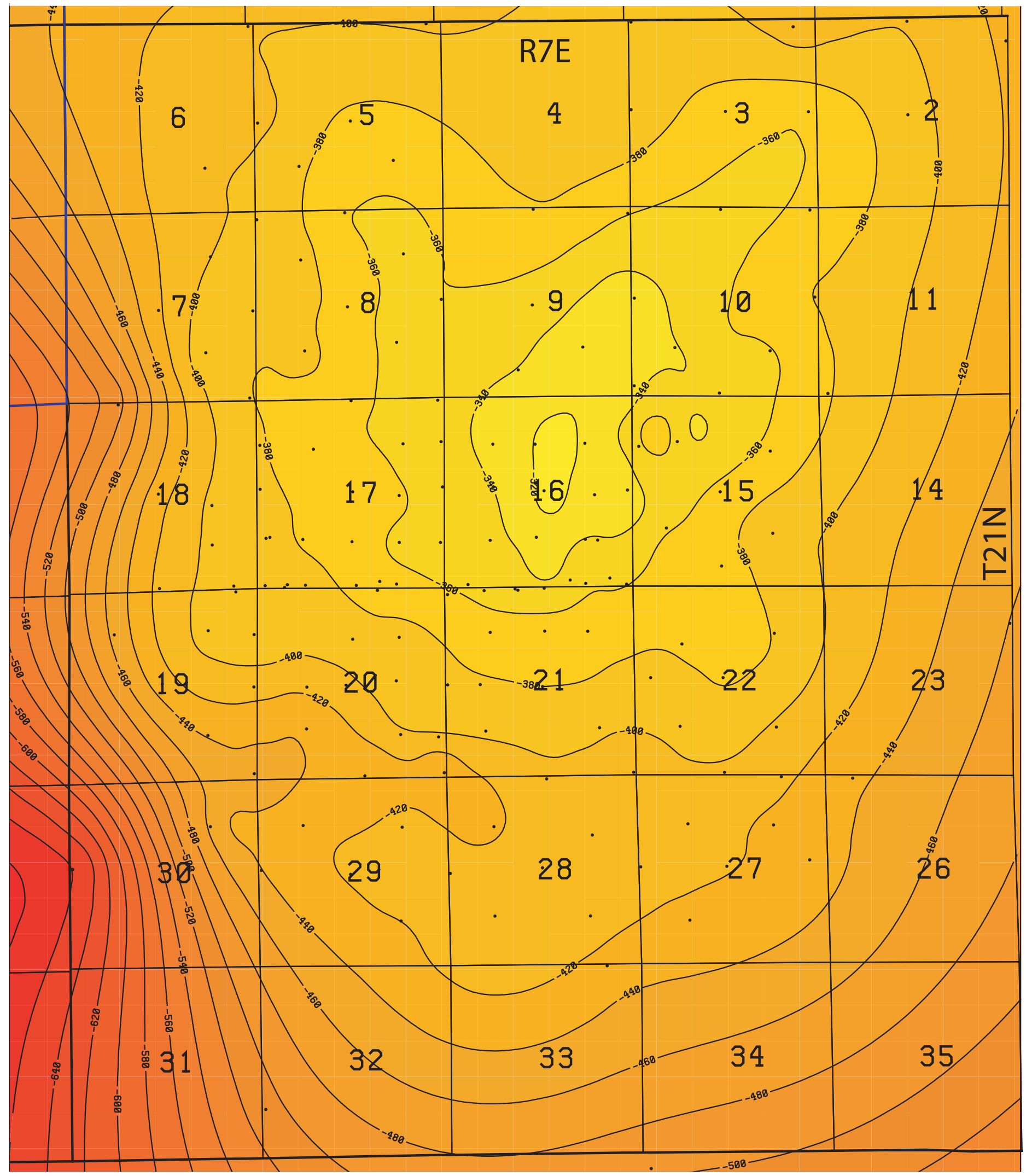

Figure 12 


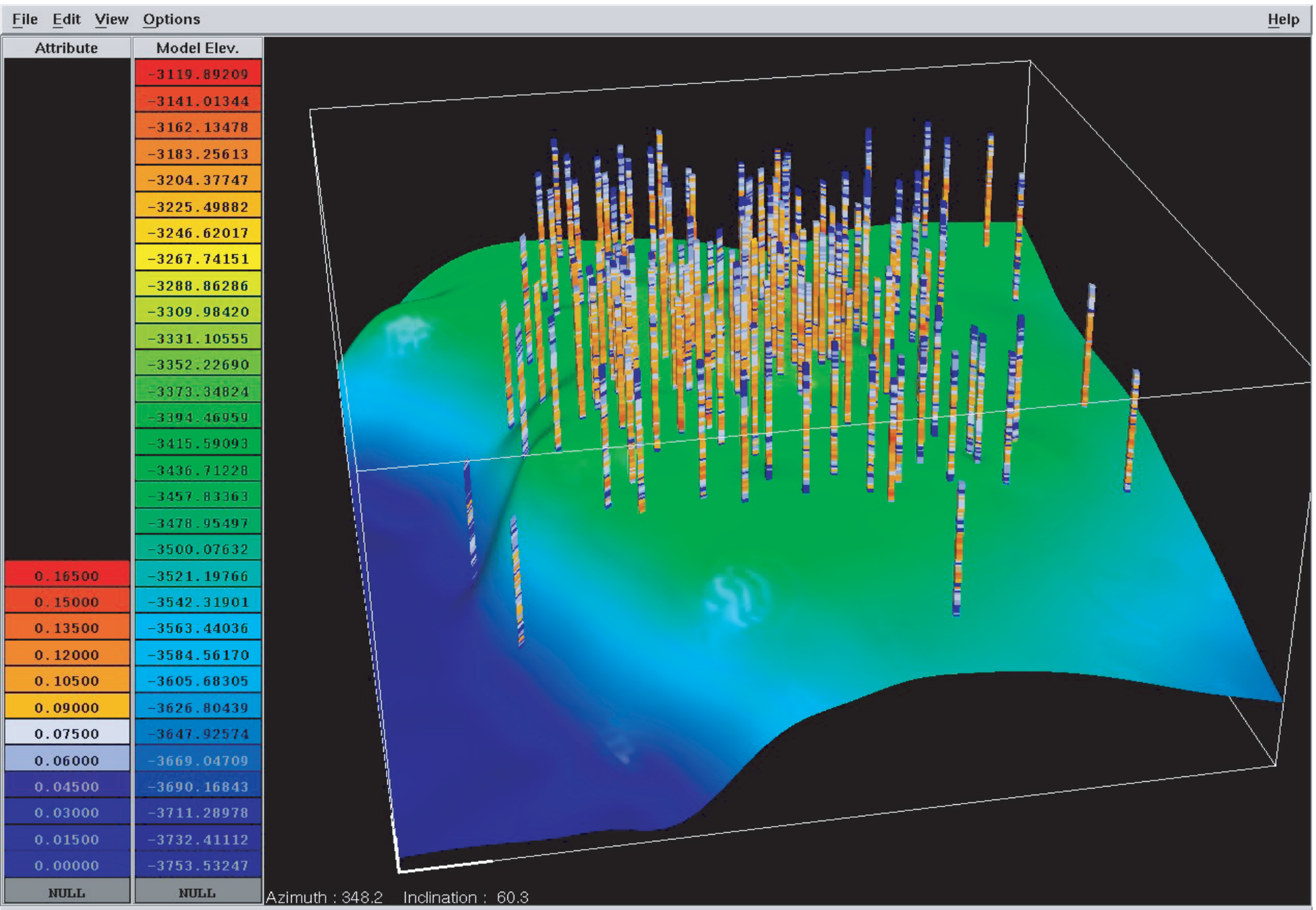

Current Attribute : A 2. PHIE

Figure 13 


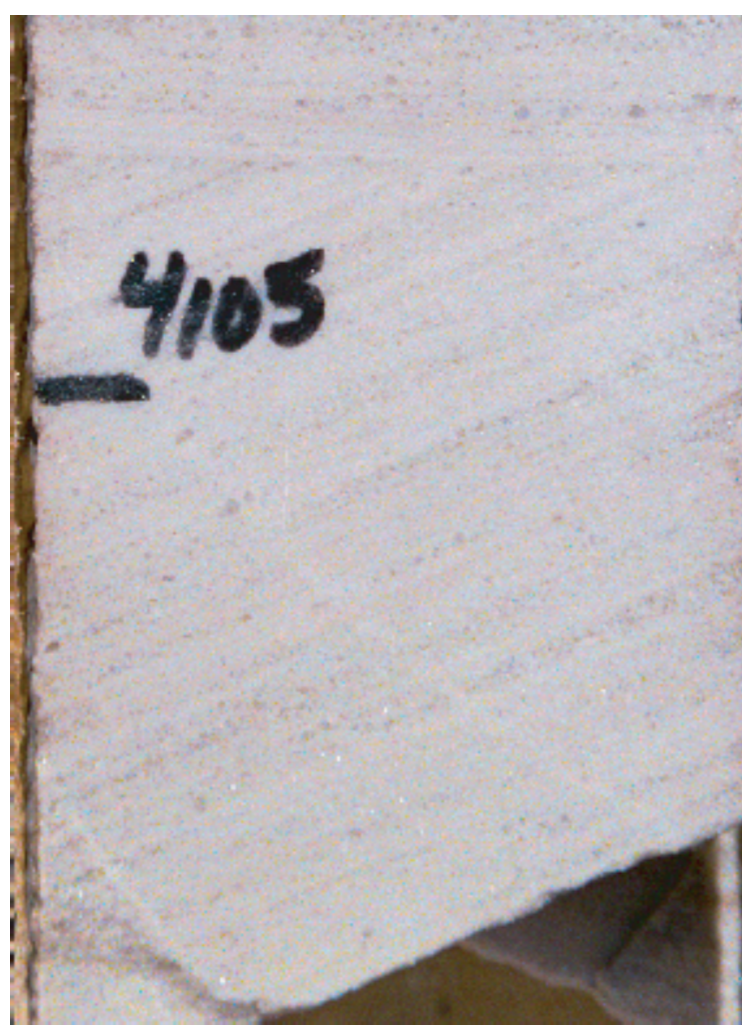

A.

Hazen \#5, 4105'

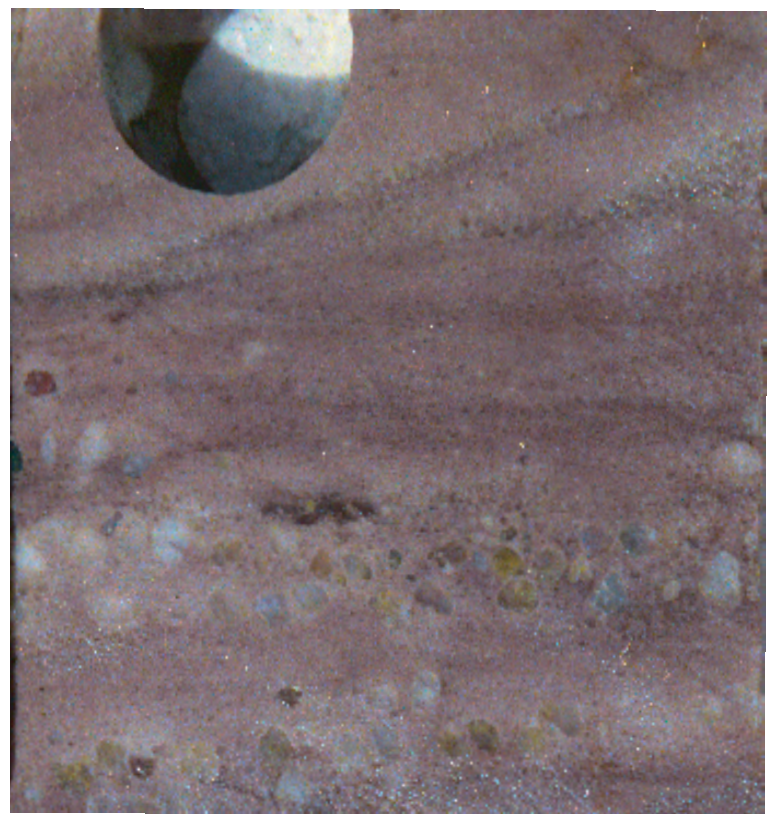

B.

J Williams \#4, 4197'

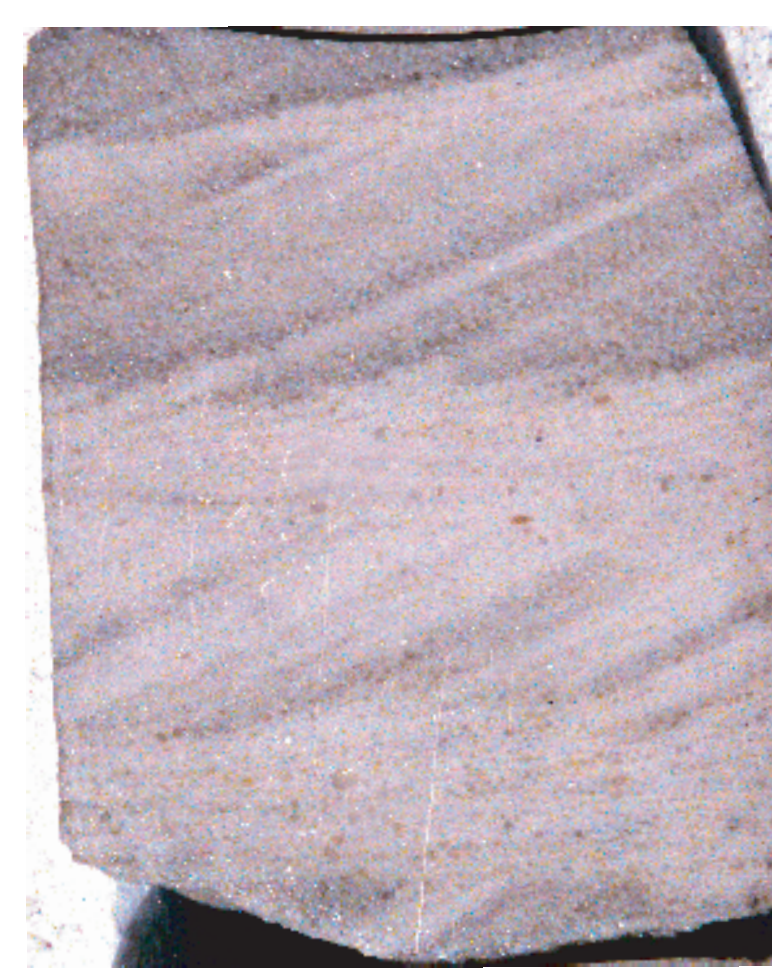

C.

J Williams \#4, 4030'

Figure 14 


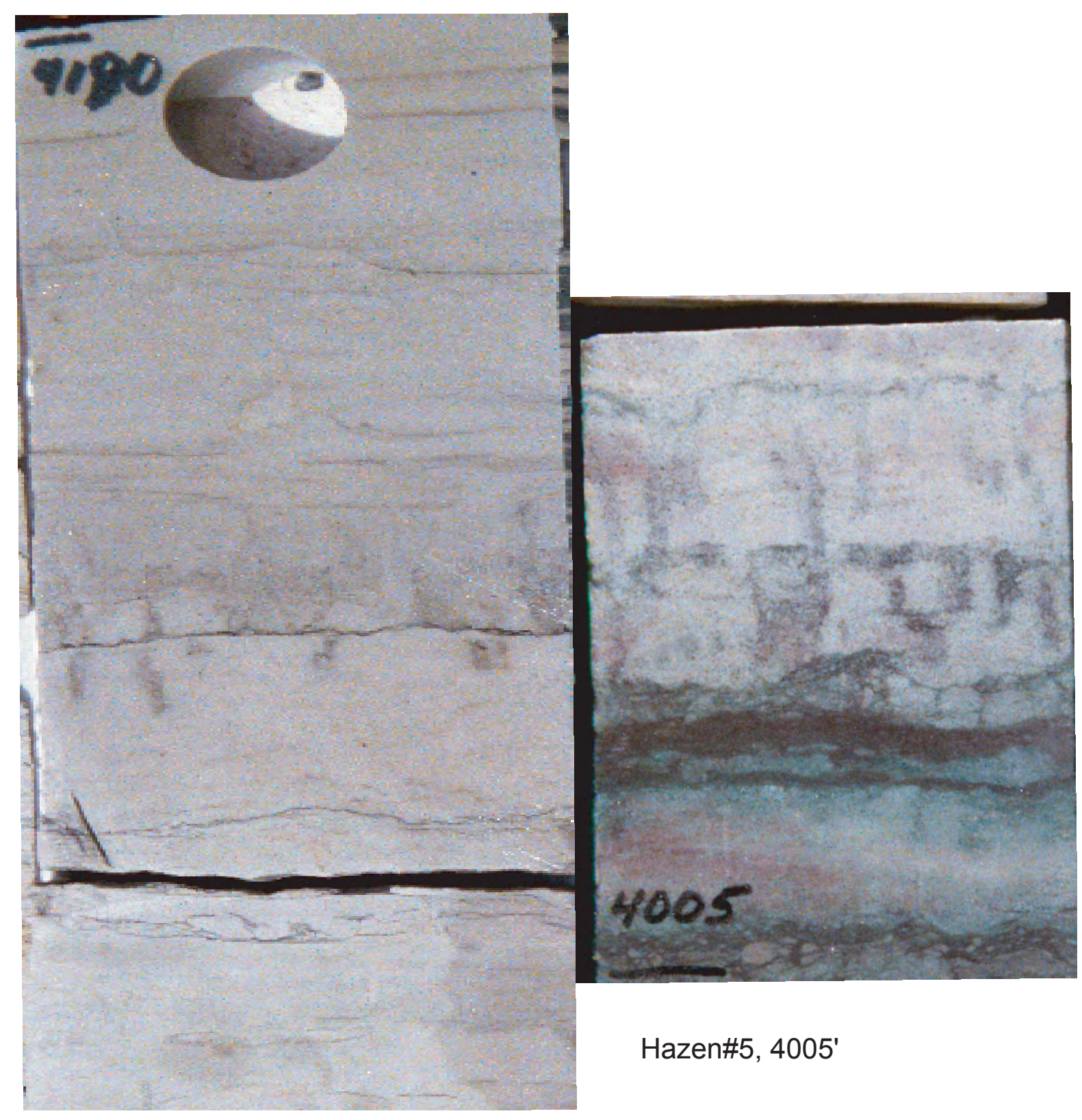

J. Williams \#4, 4180'

Figure 15 


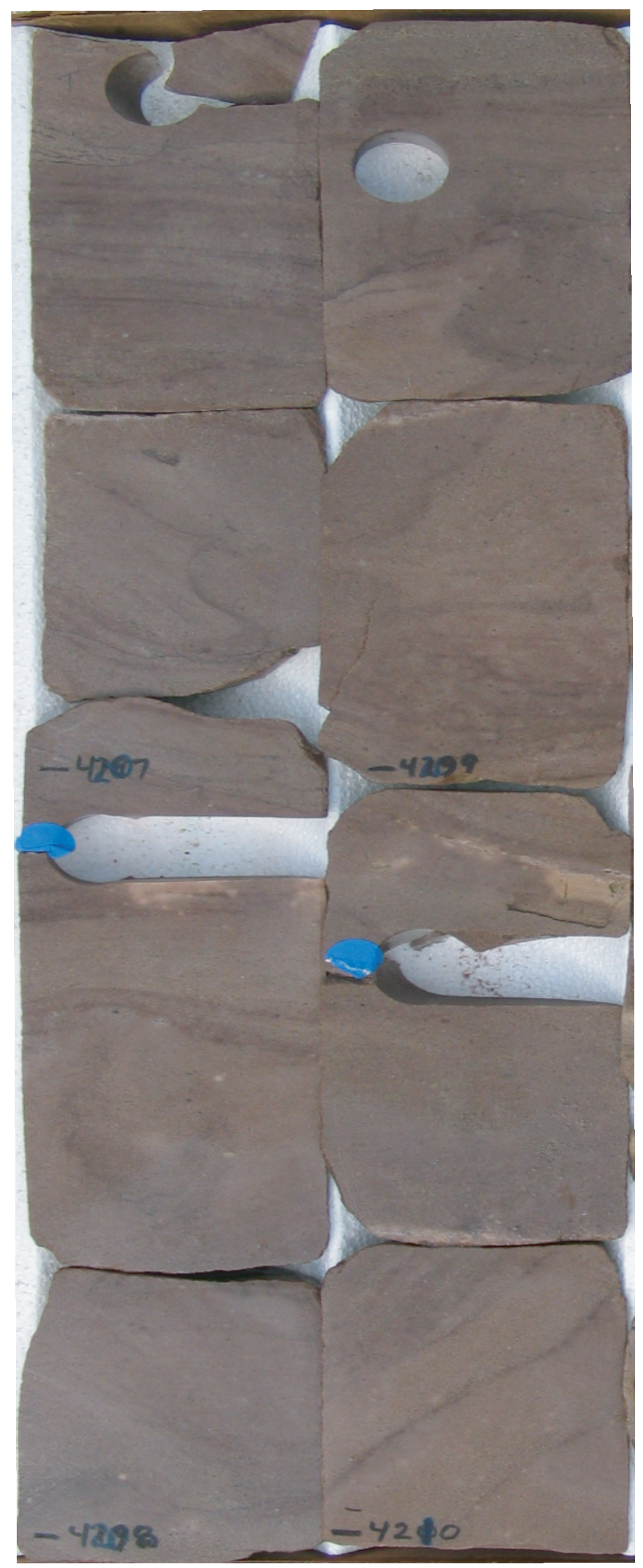

J. Williams \#4, 4206'-4210'

Figure 16 


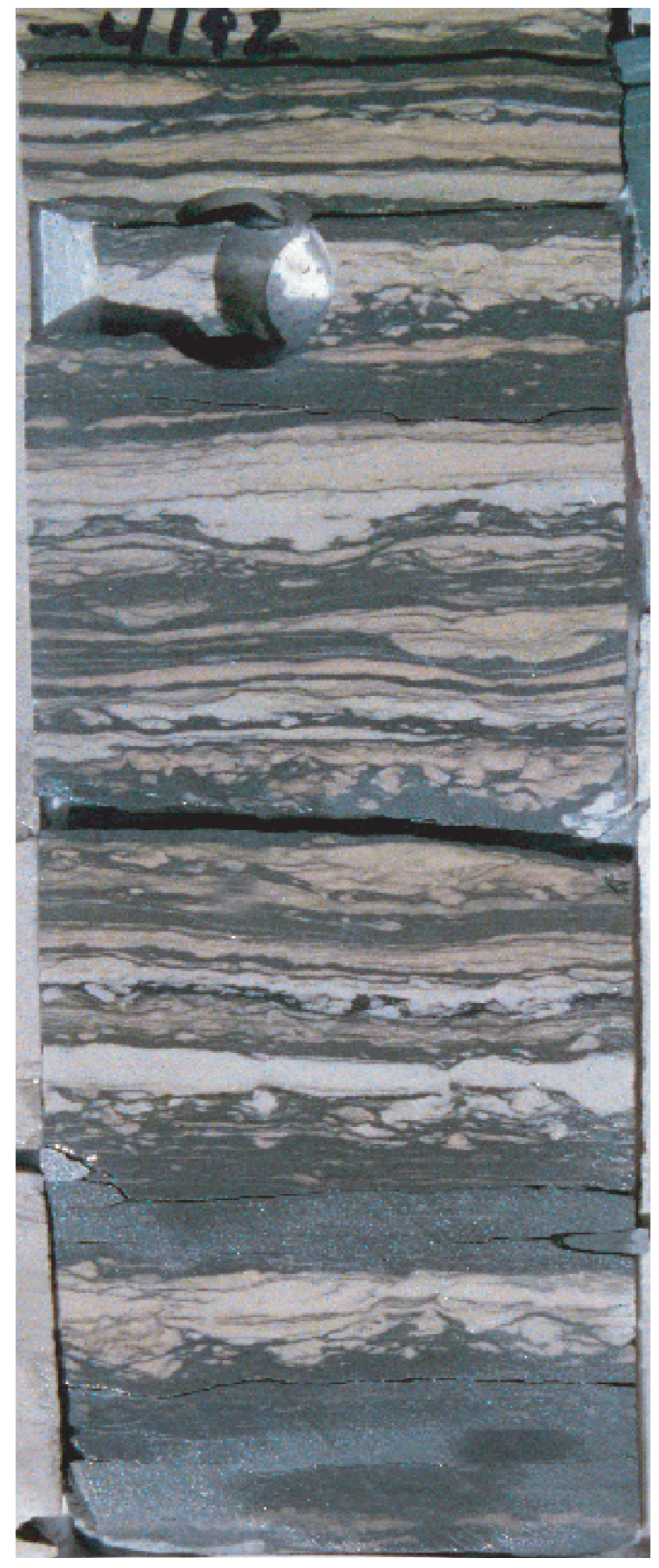

A. J.Williams \#4,4192'

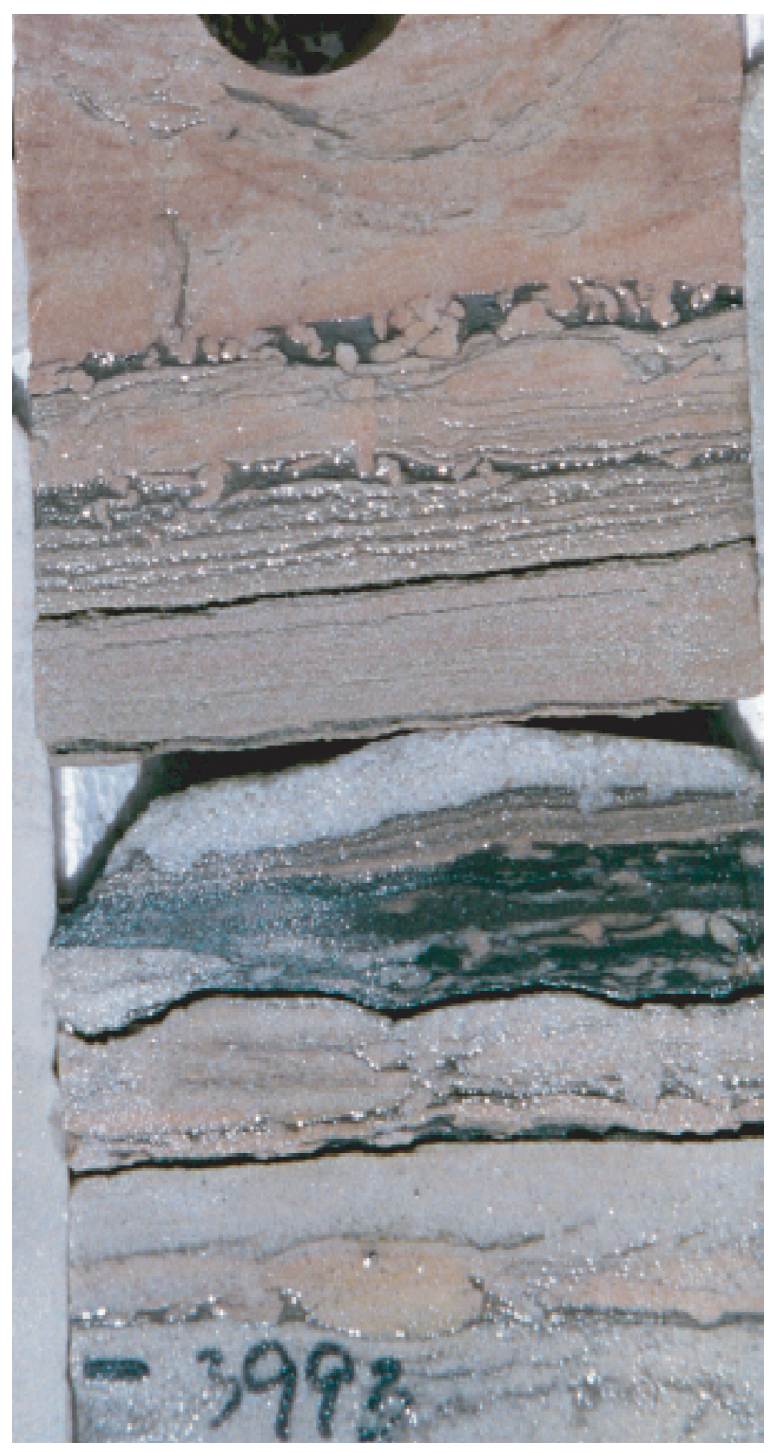

B. J.Williams \#4, 3993'

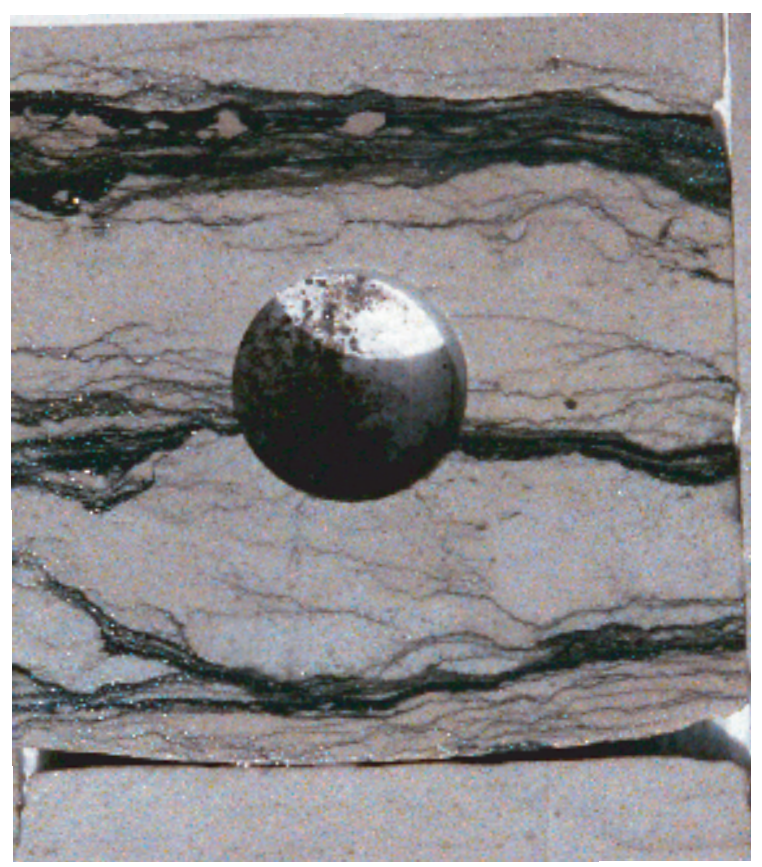

C. J.Williams \#4, 3997' 


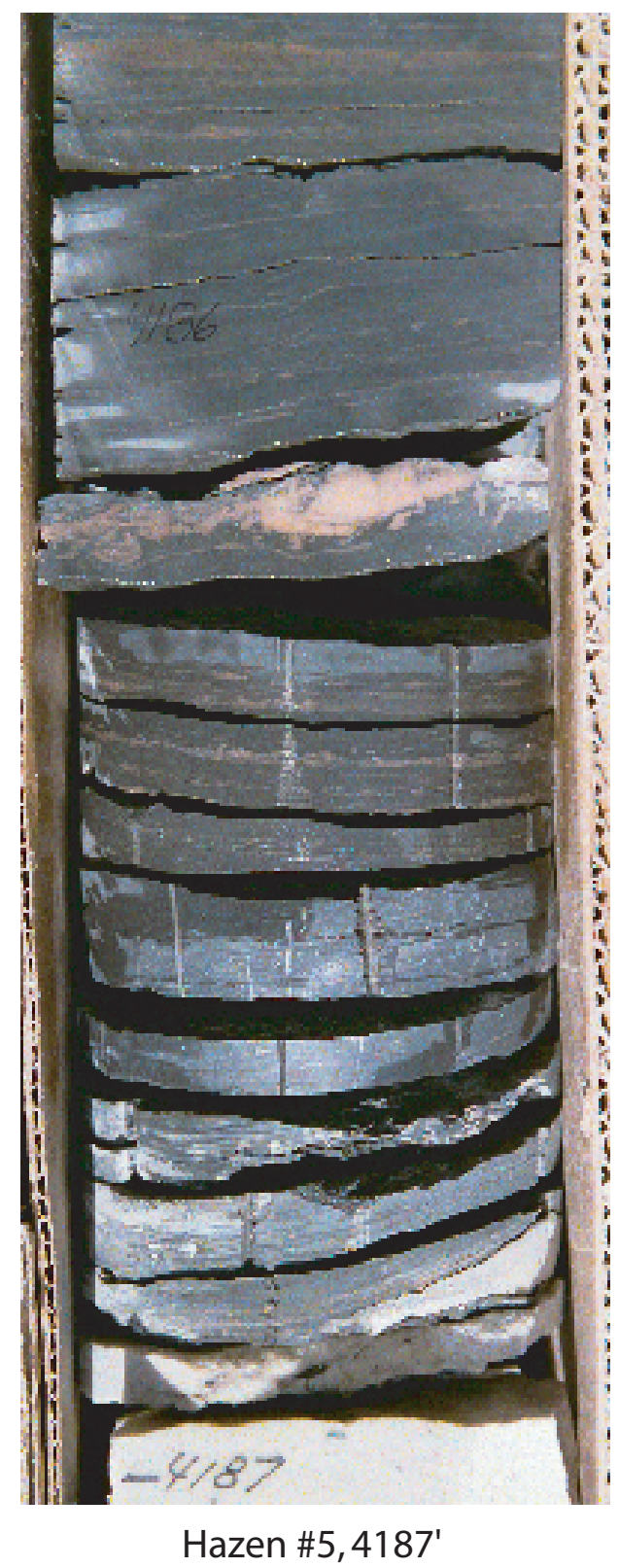

Figure 18 


\section{J. Williams \#4 \\ Manlove Field}

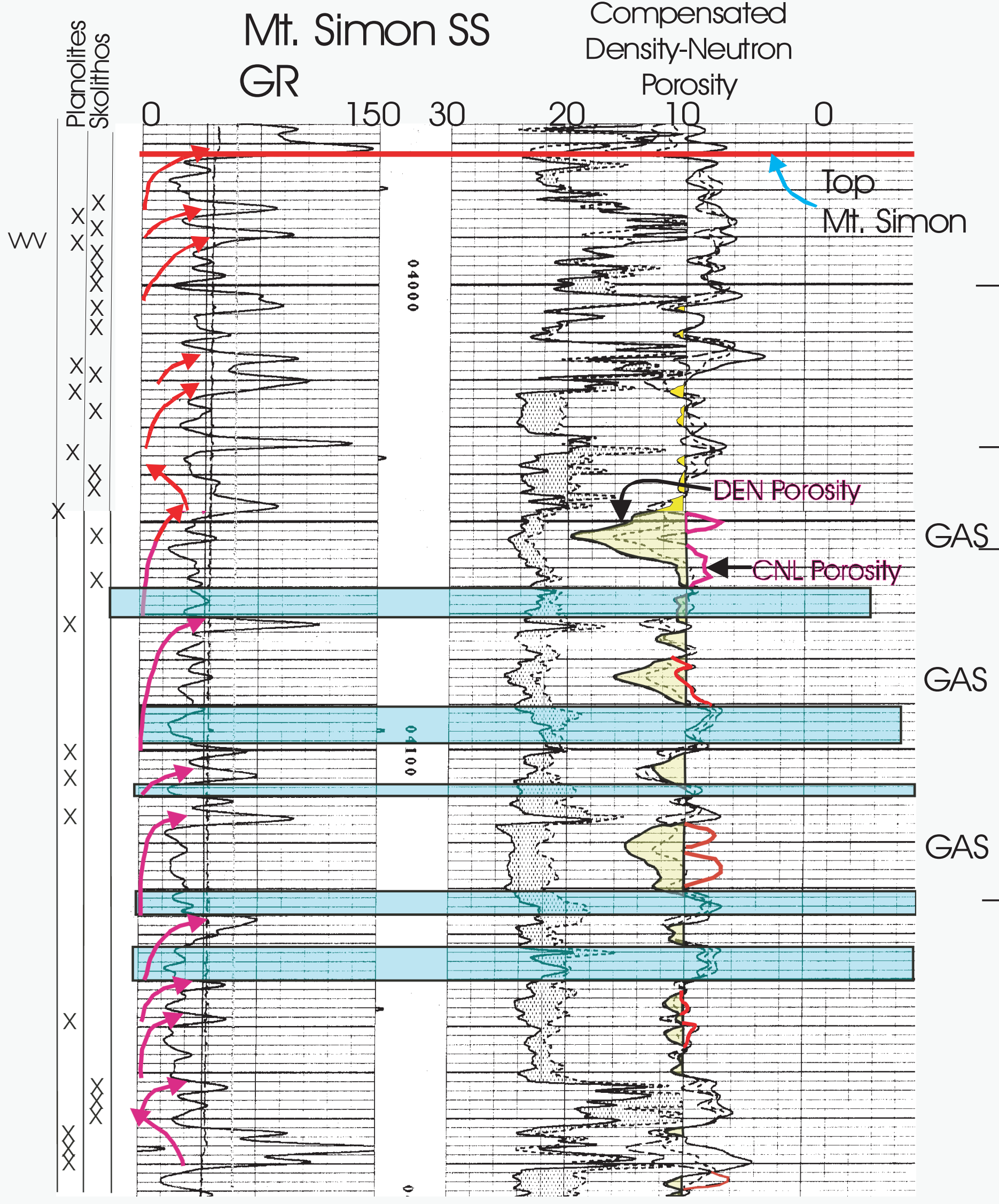




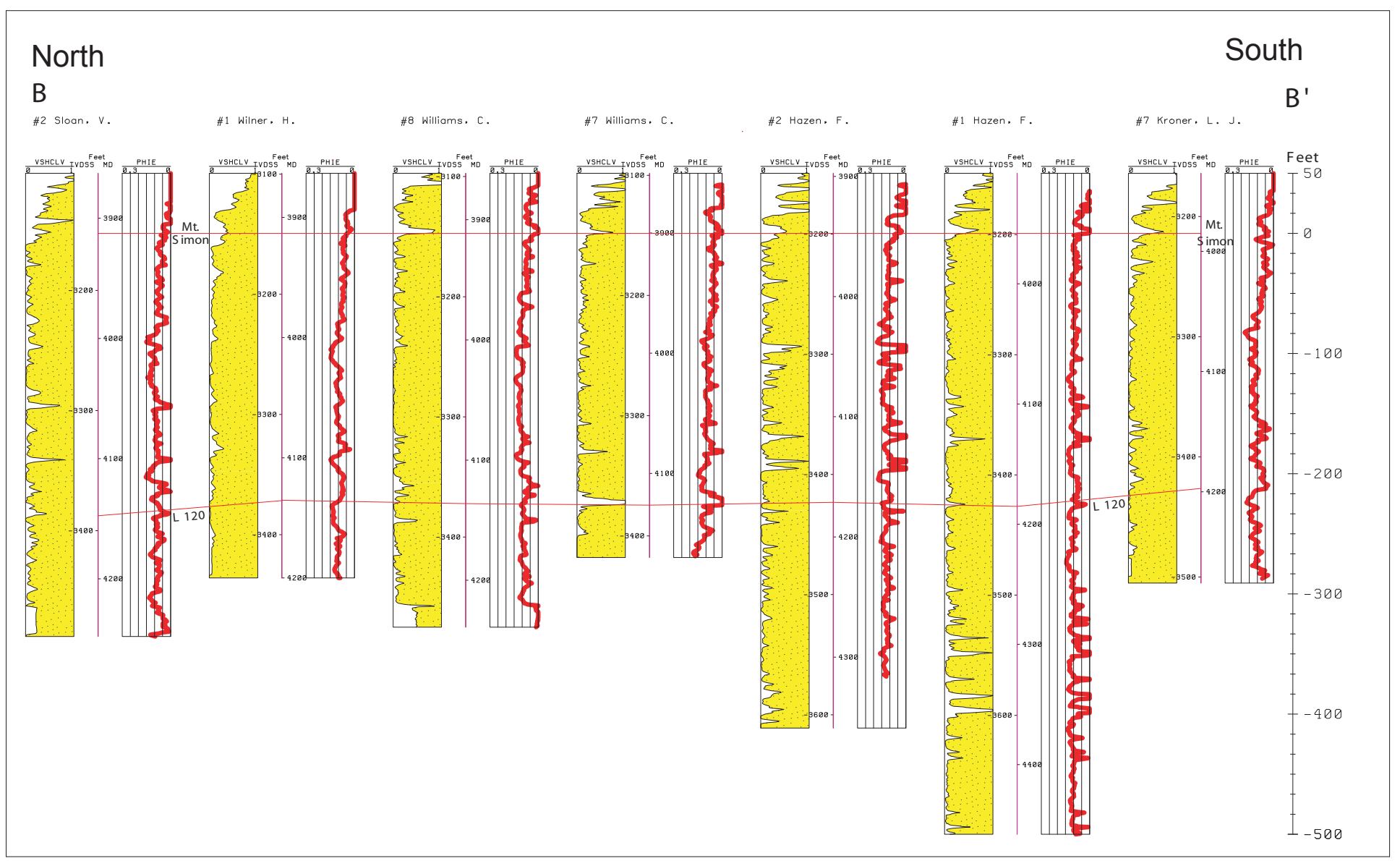

Figure 20 


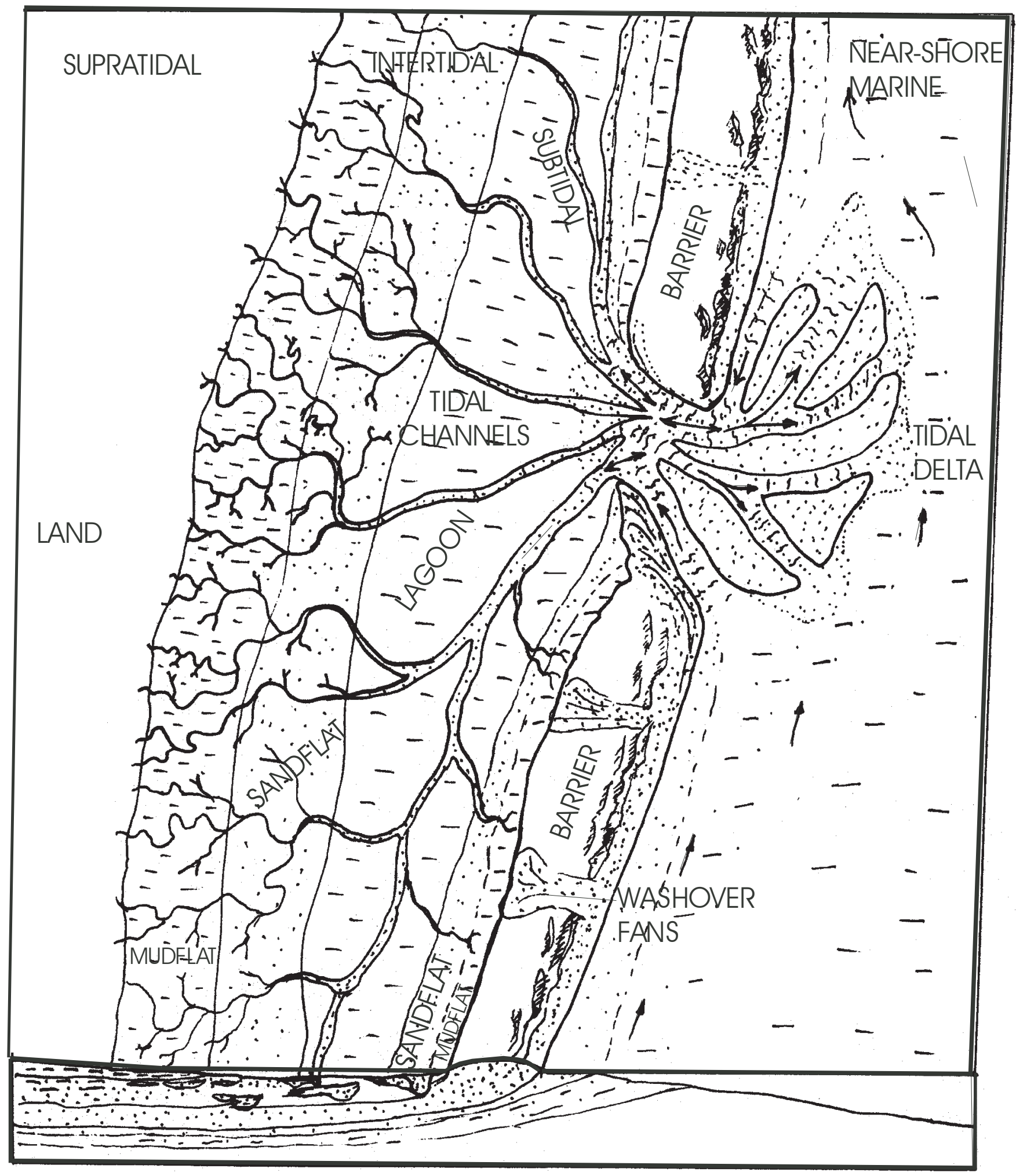

Figure 21 


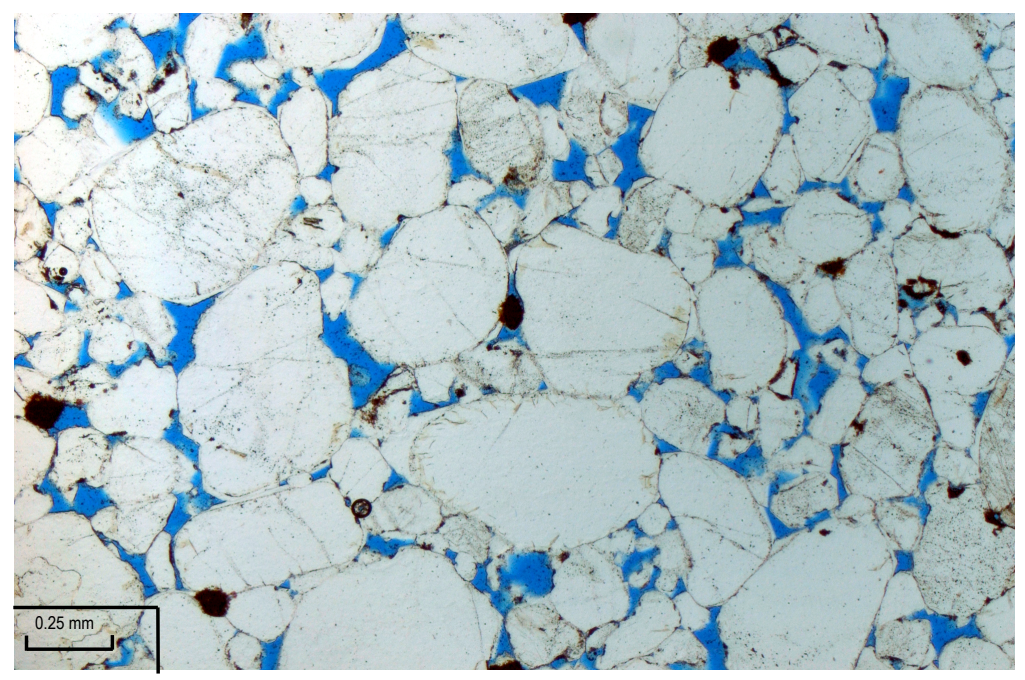

A.) J.Williams \#4, 4209.1'

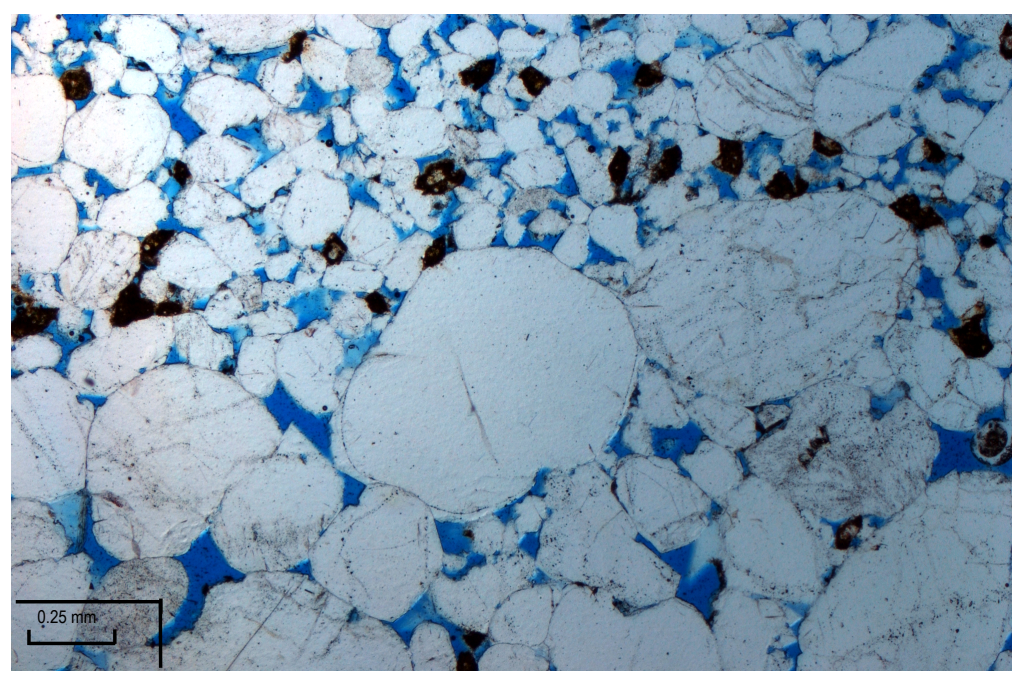

B.) J.Williams \#4, 4124.3'

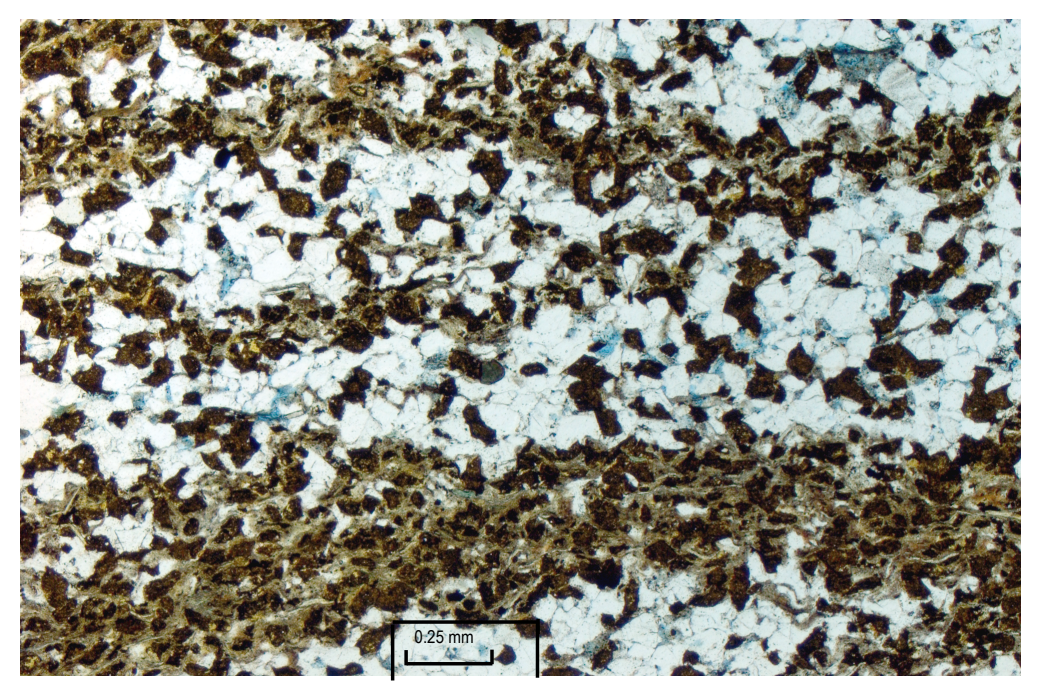

C.) J.Williams \#4, 4195.2'

Figure 22 


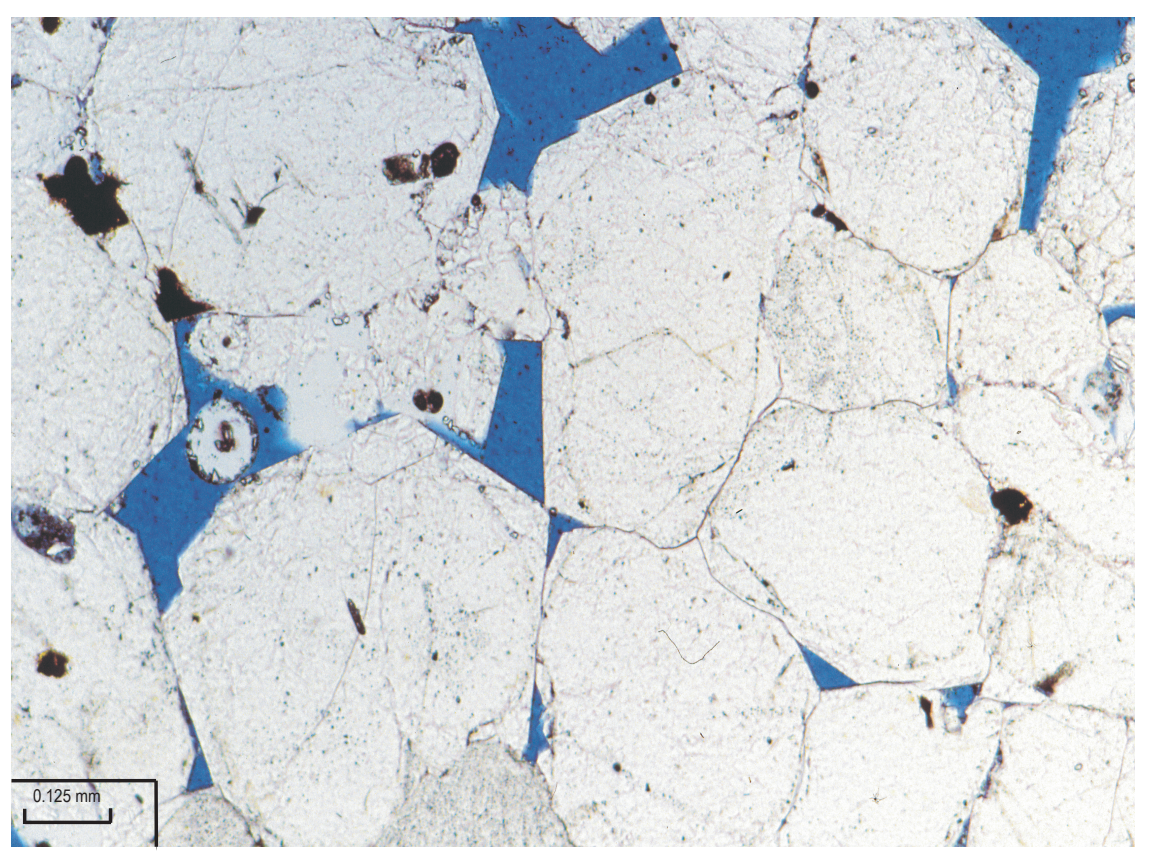

A.) JWilliams \#4, 4051'

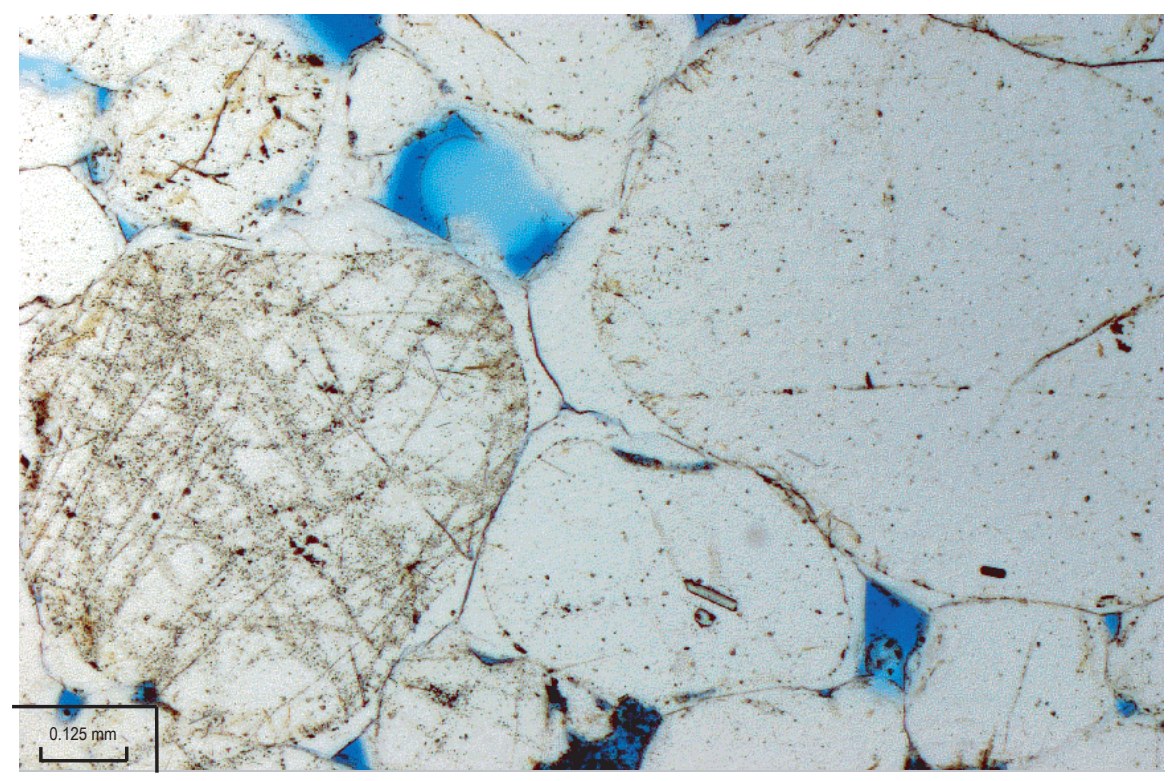

B.) J.Williams \#4,4004.9'

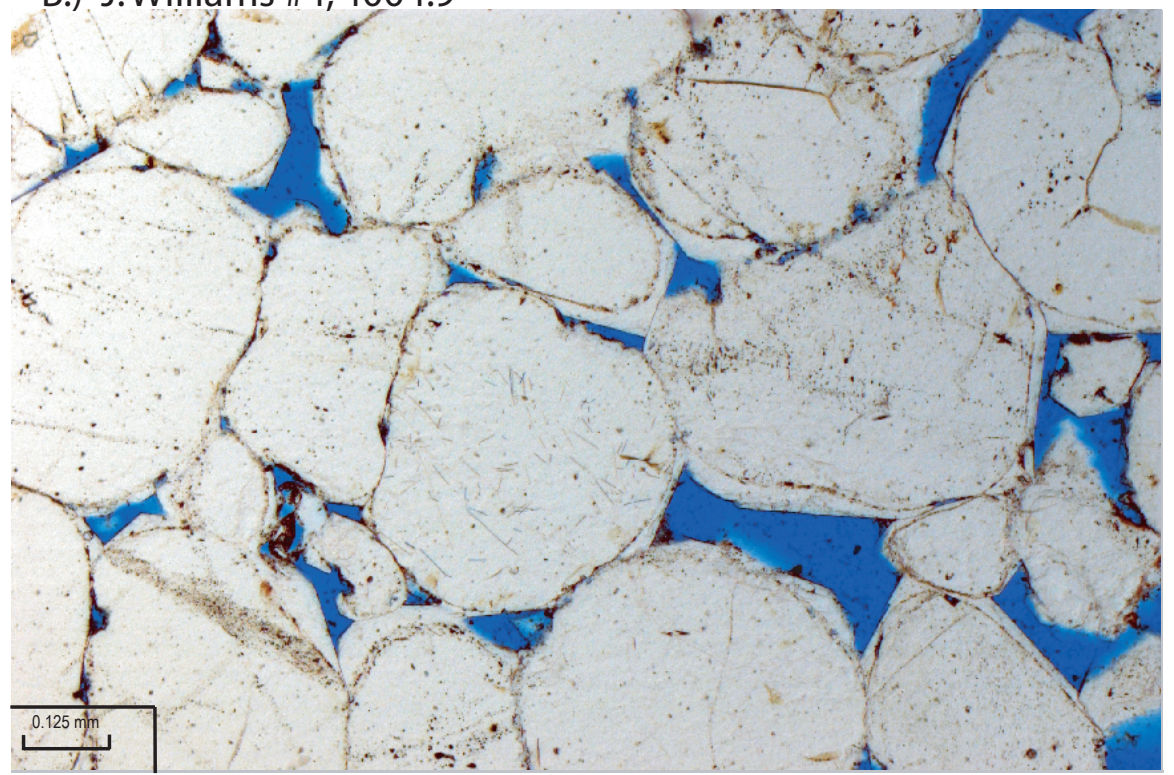




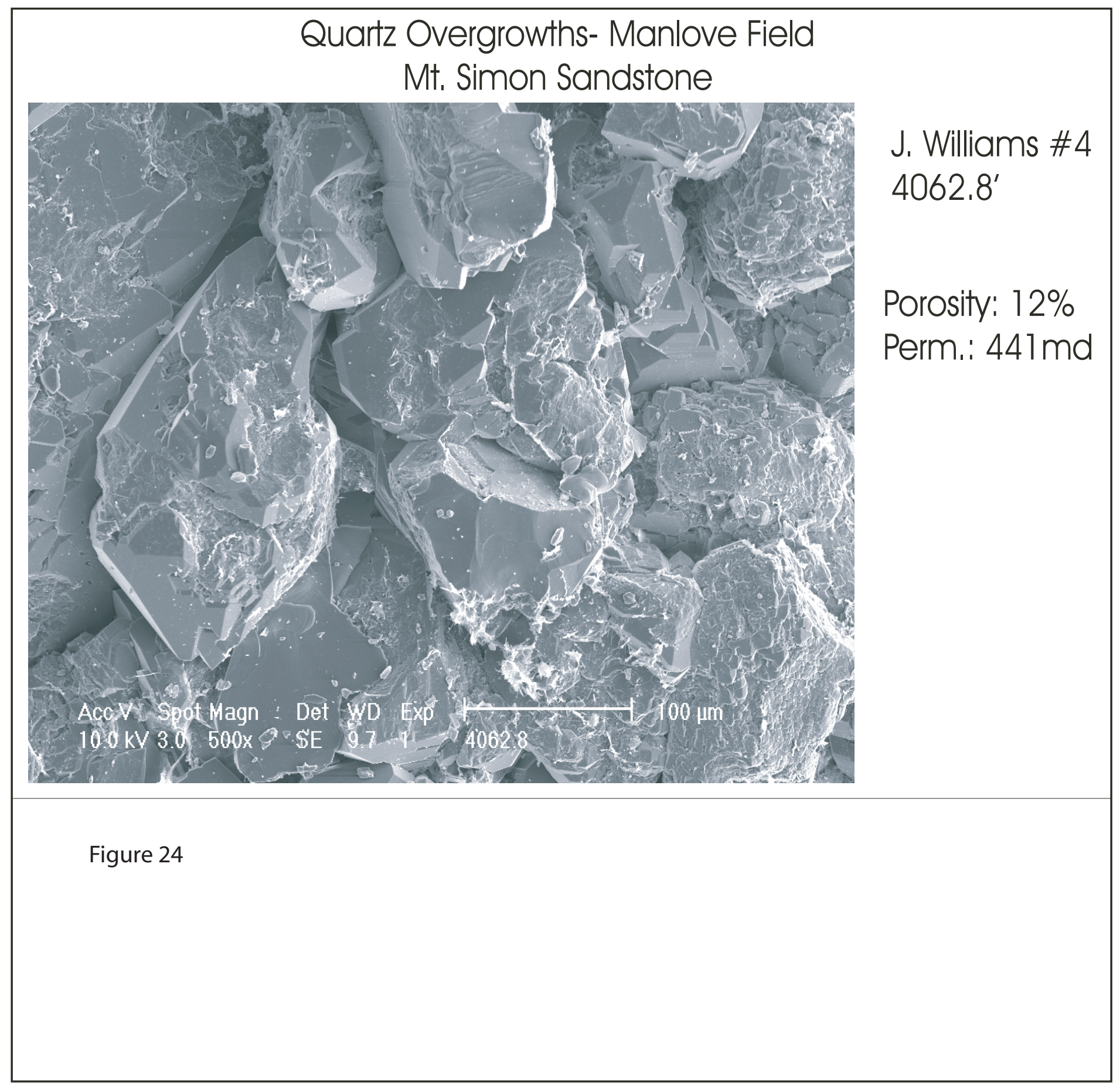




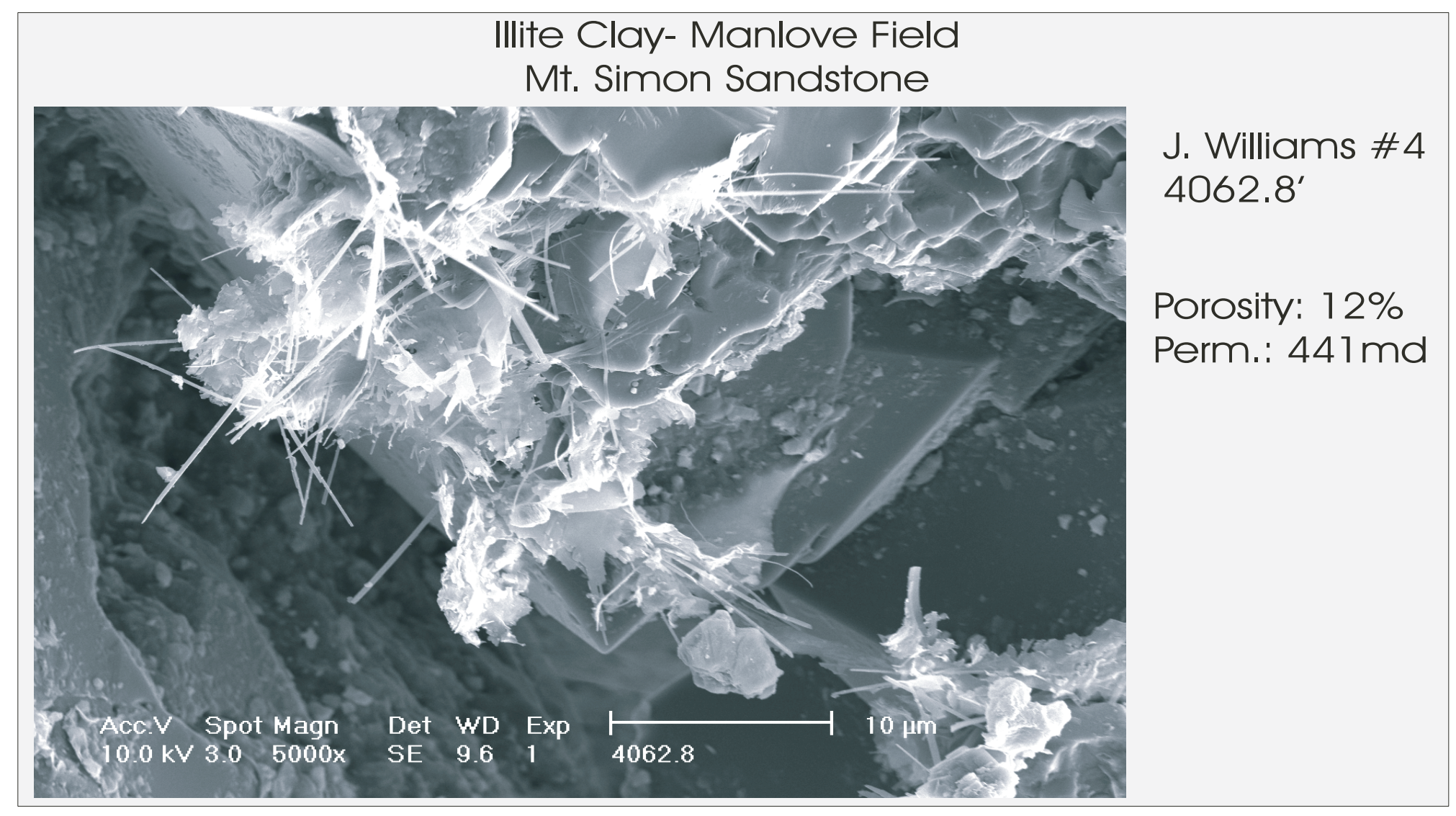

Figure 25 


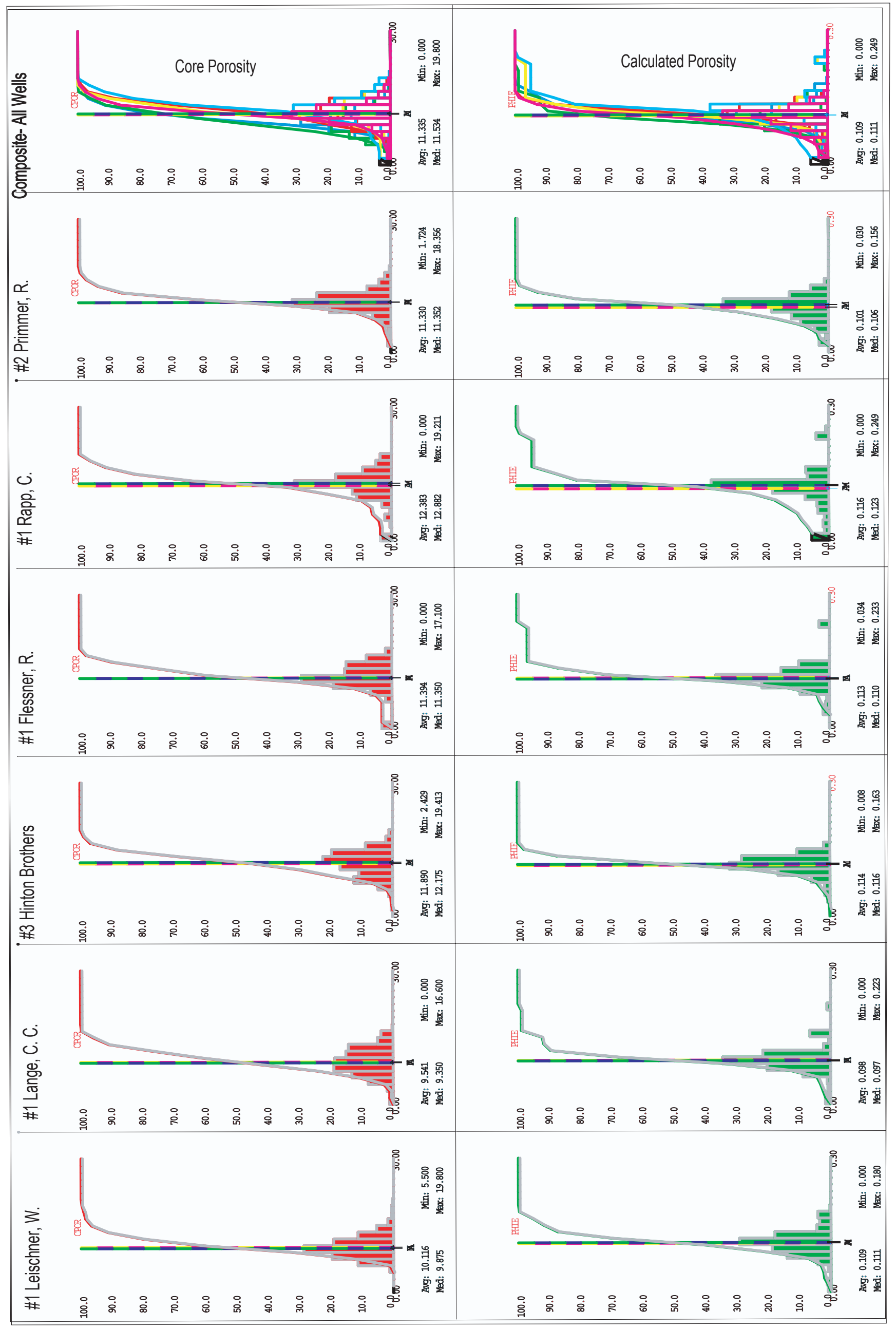

Figure 26 


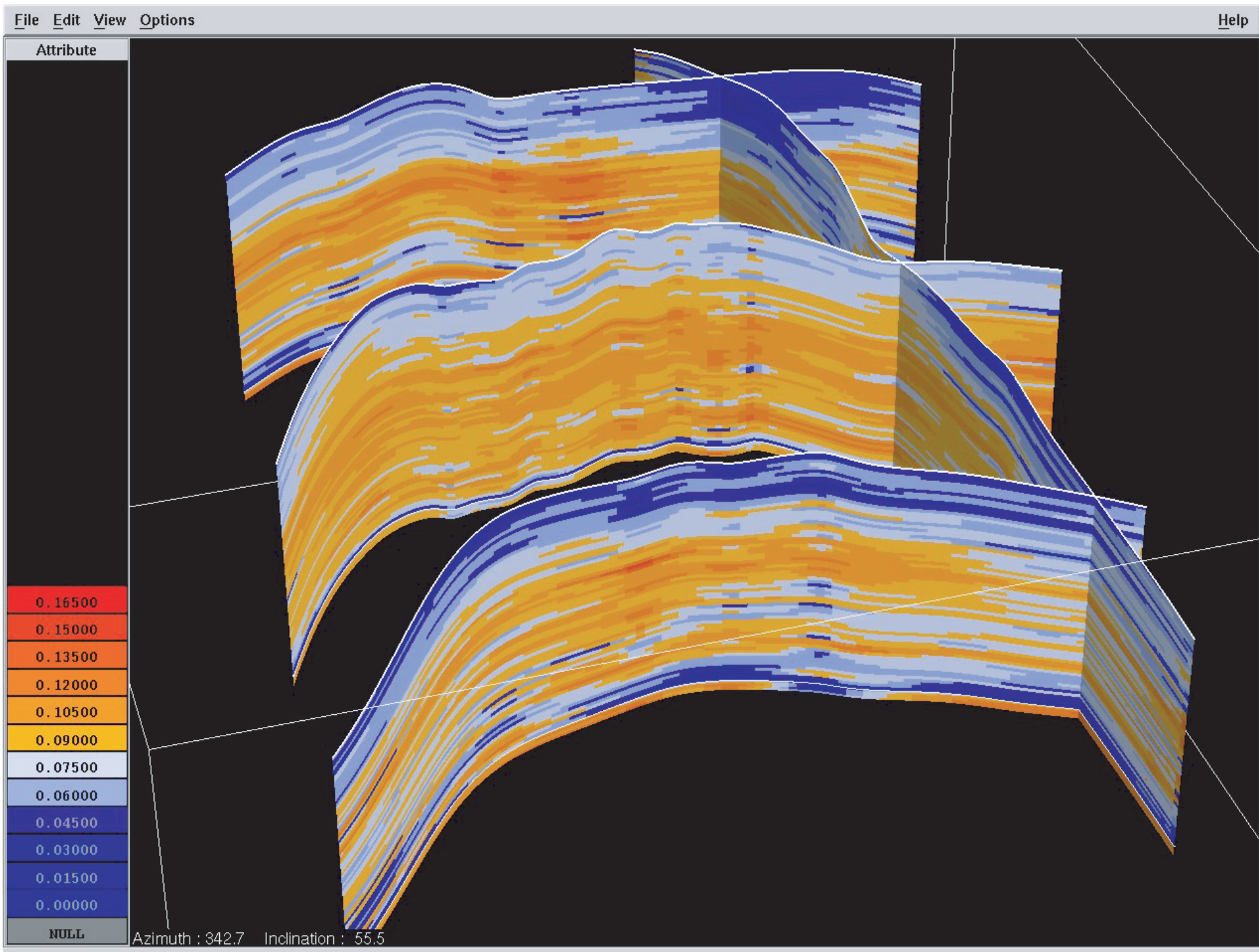

Current Attribute : A 2. PHIE

Figure 27 

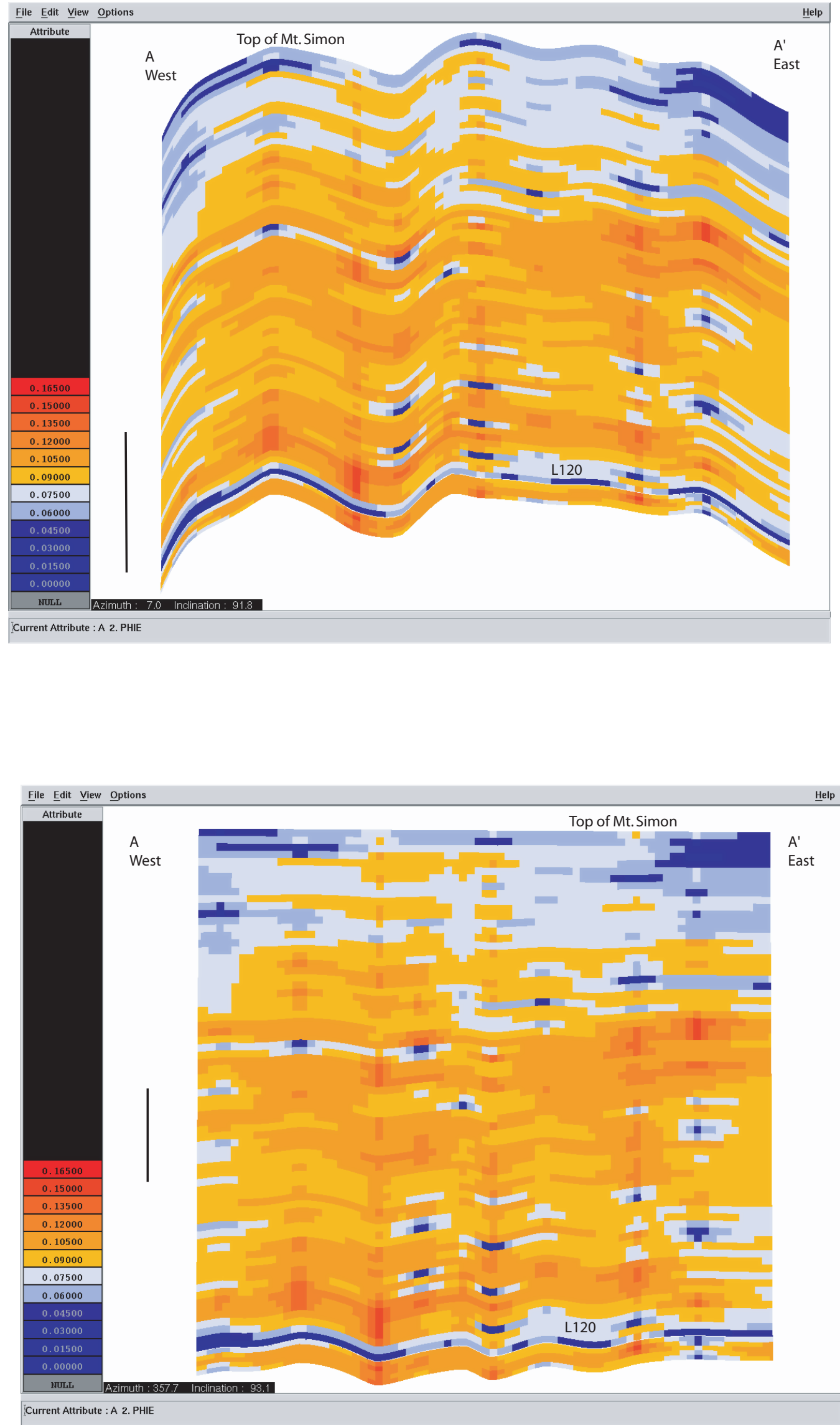

Figure 28 

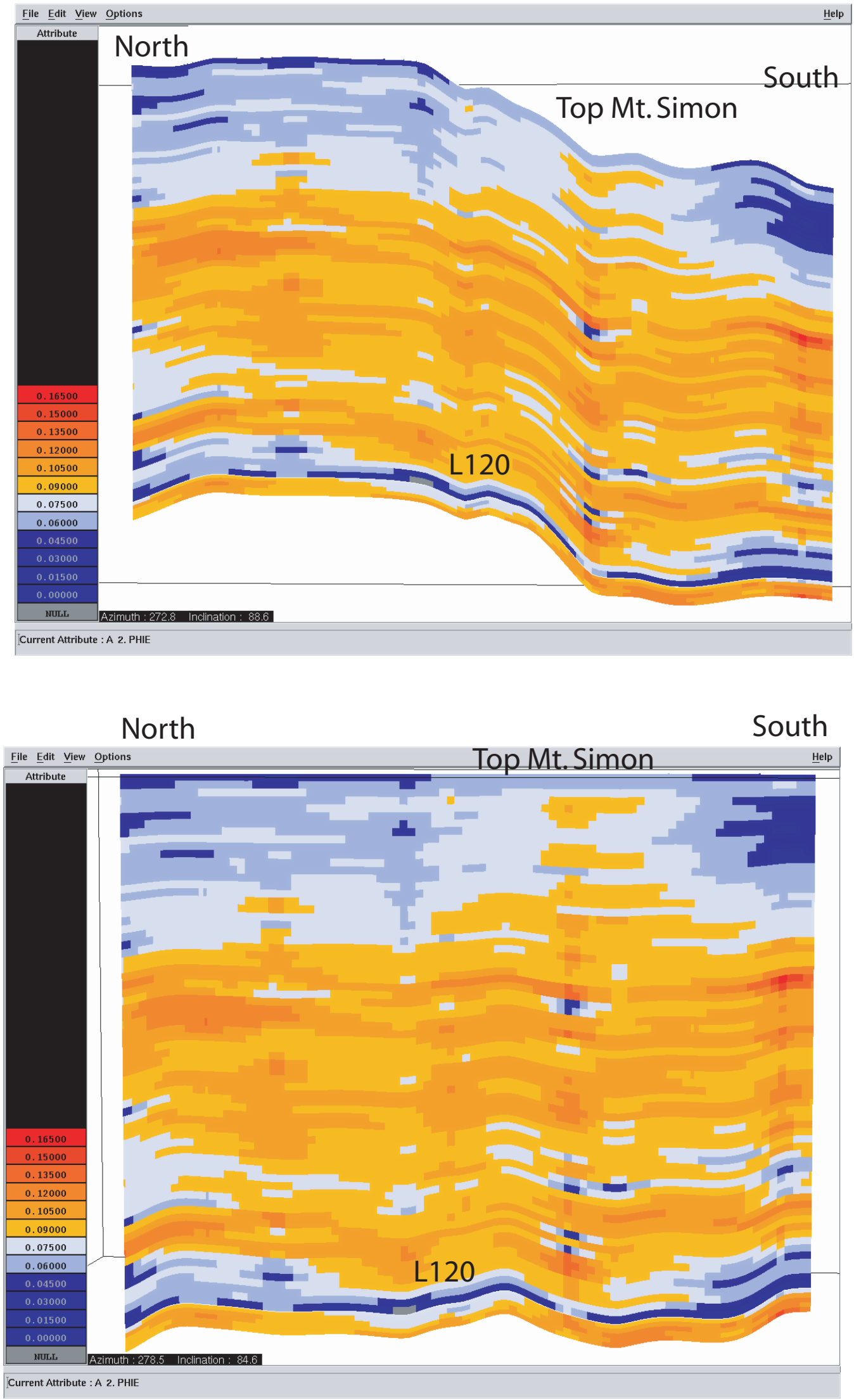

Figure 29 


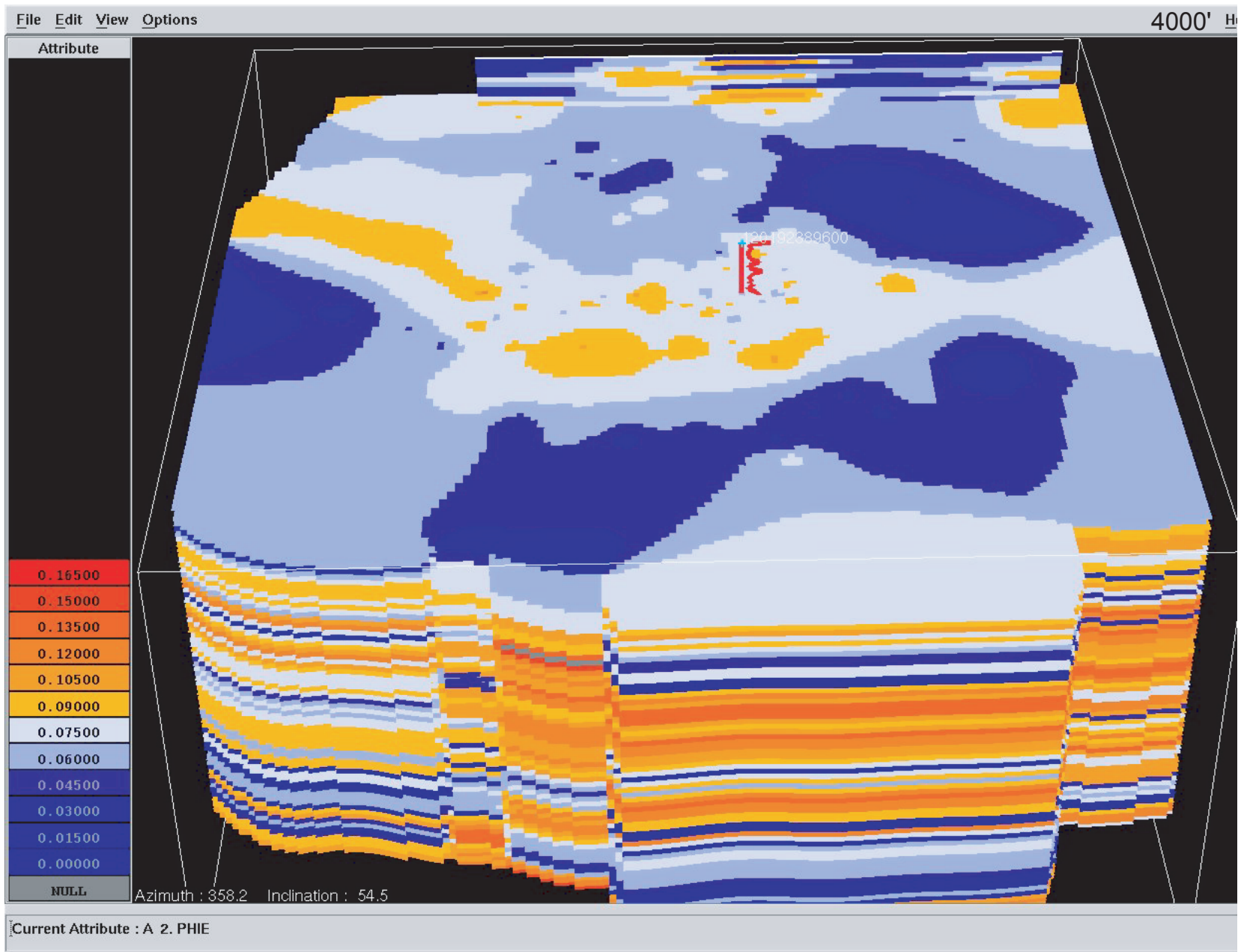

Figure 30 


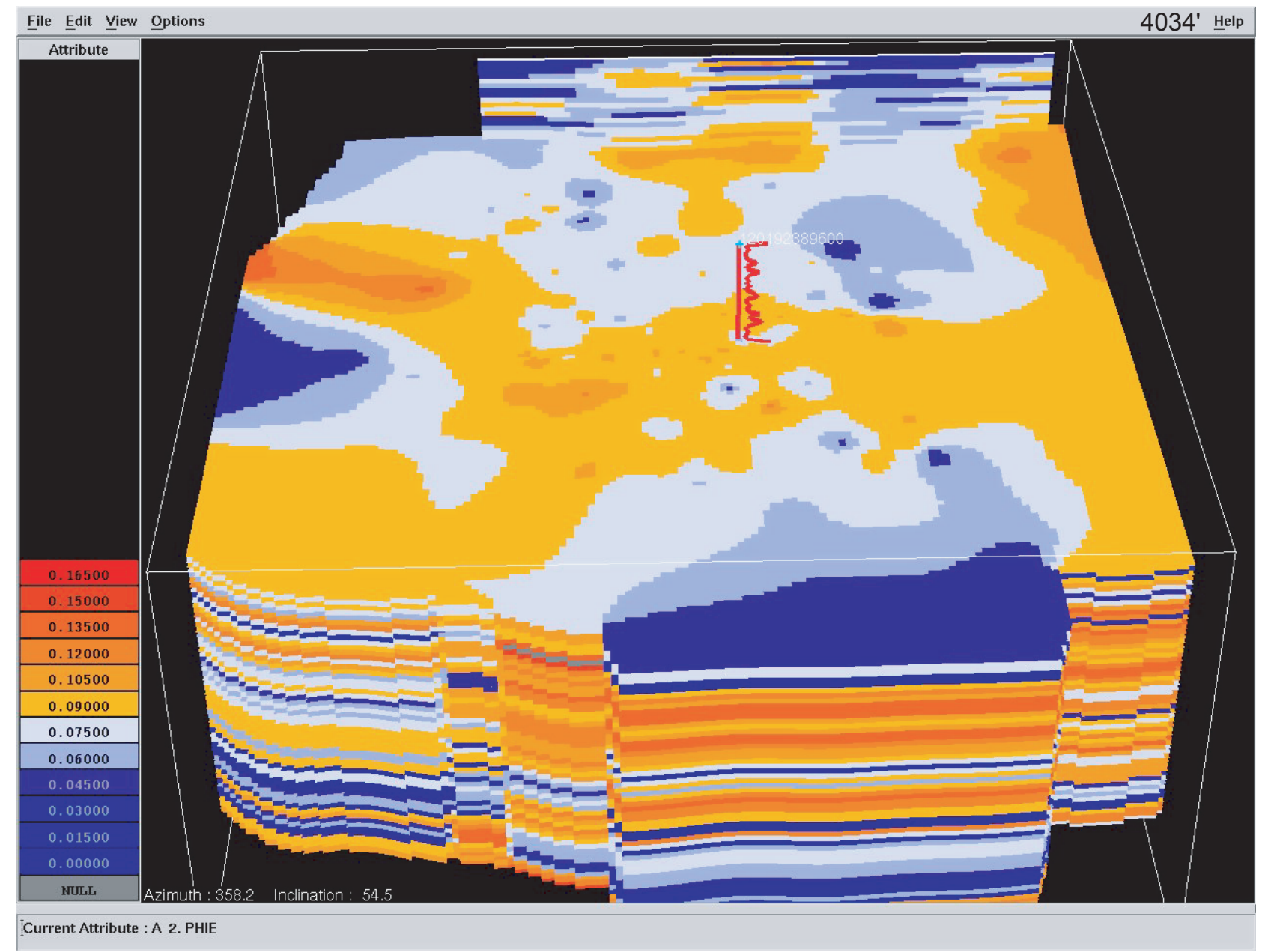

Figure 31 


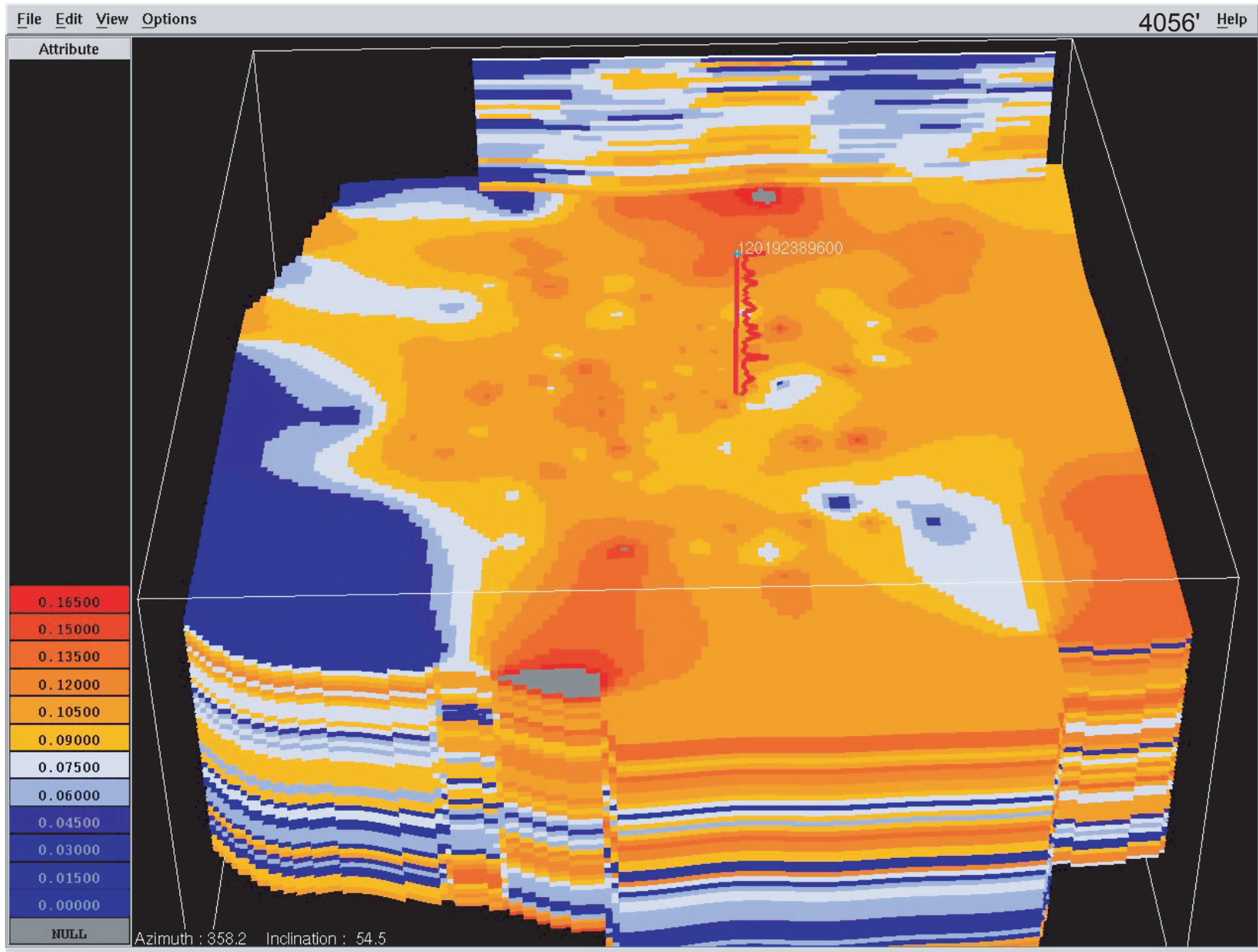

Current Attribute : A 2. PHIE

Figure 32 


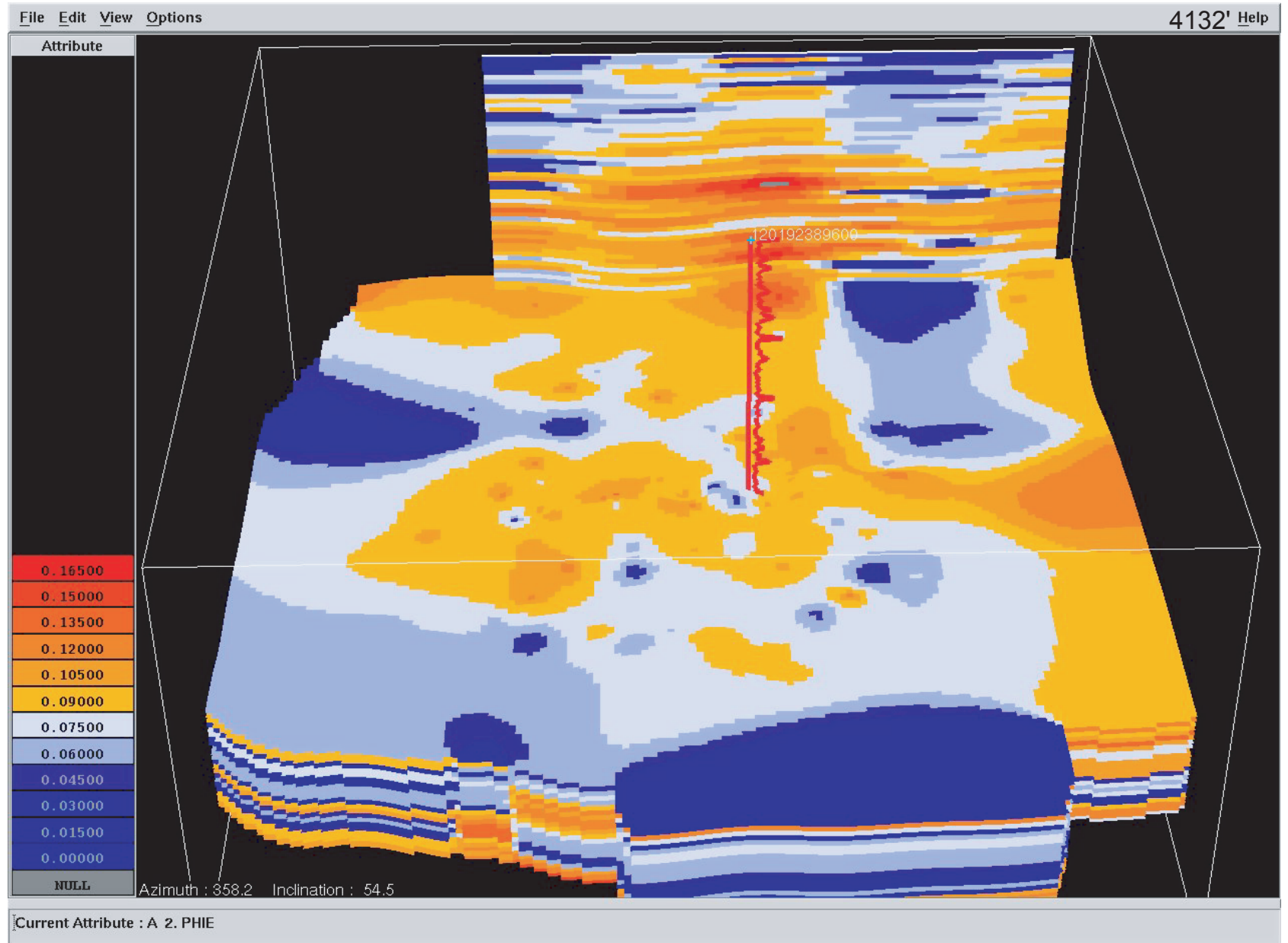

Figure 33 


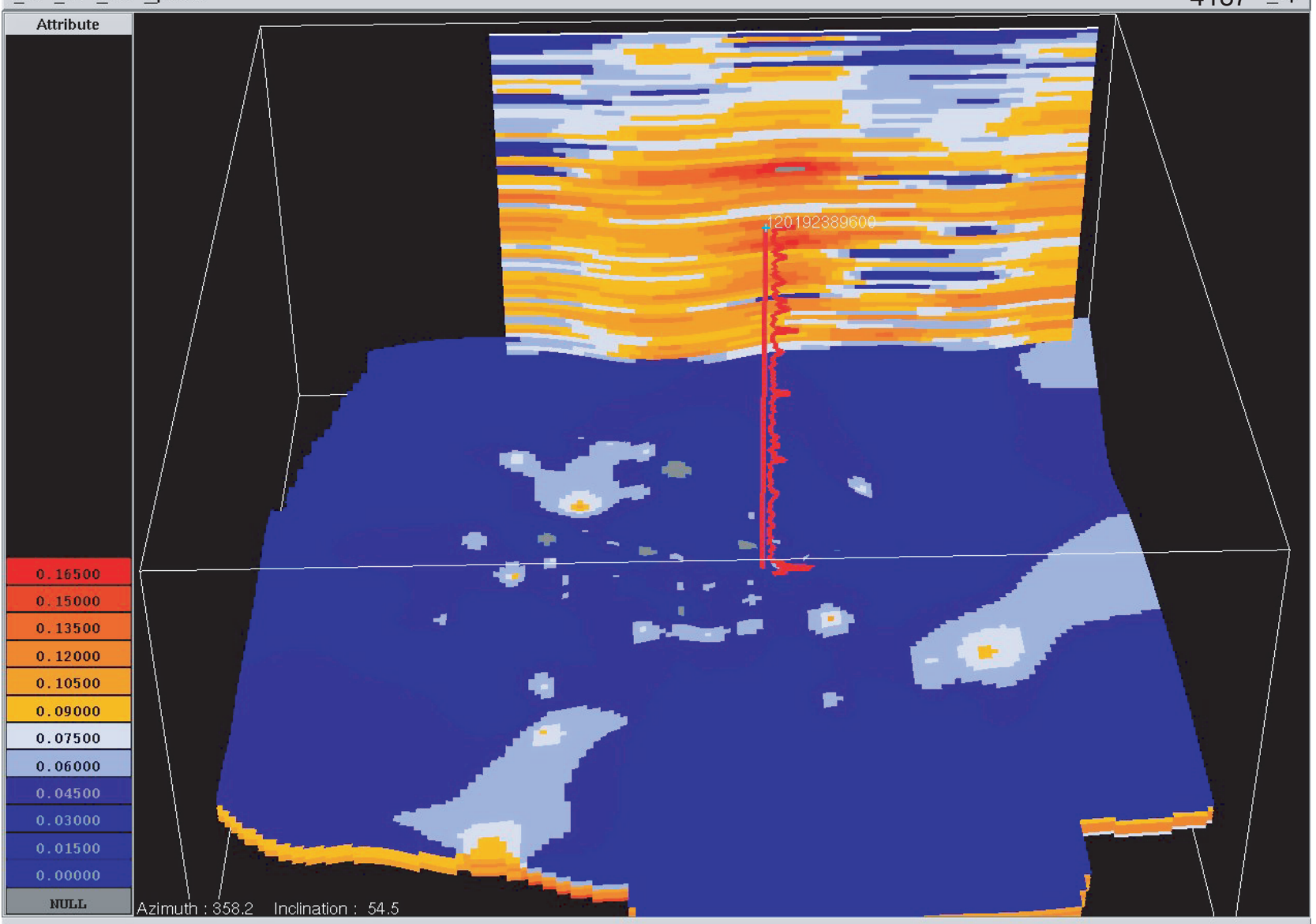

Current Attribute : A 2. PHIE

Figure 34 

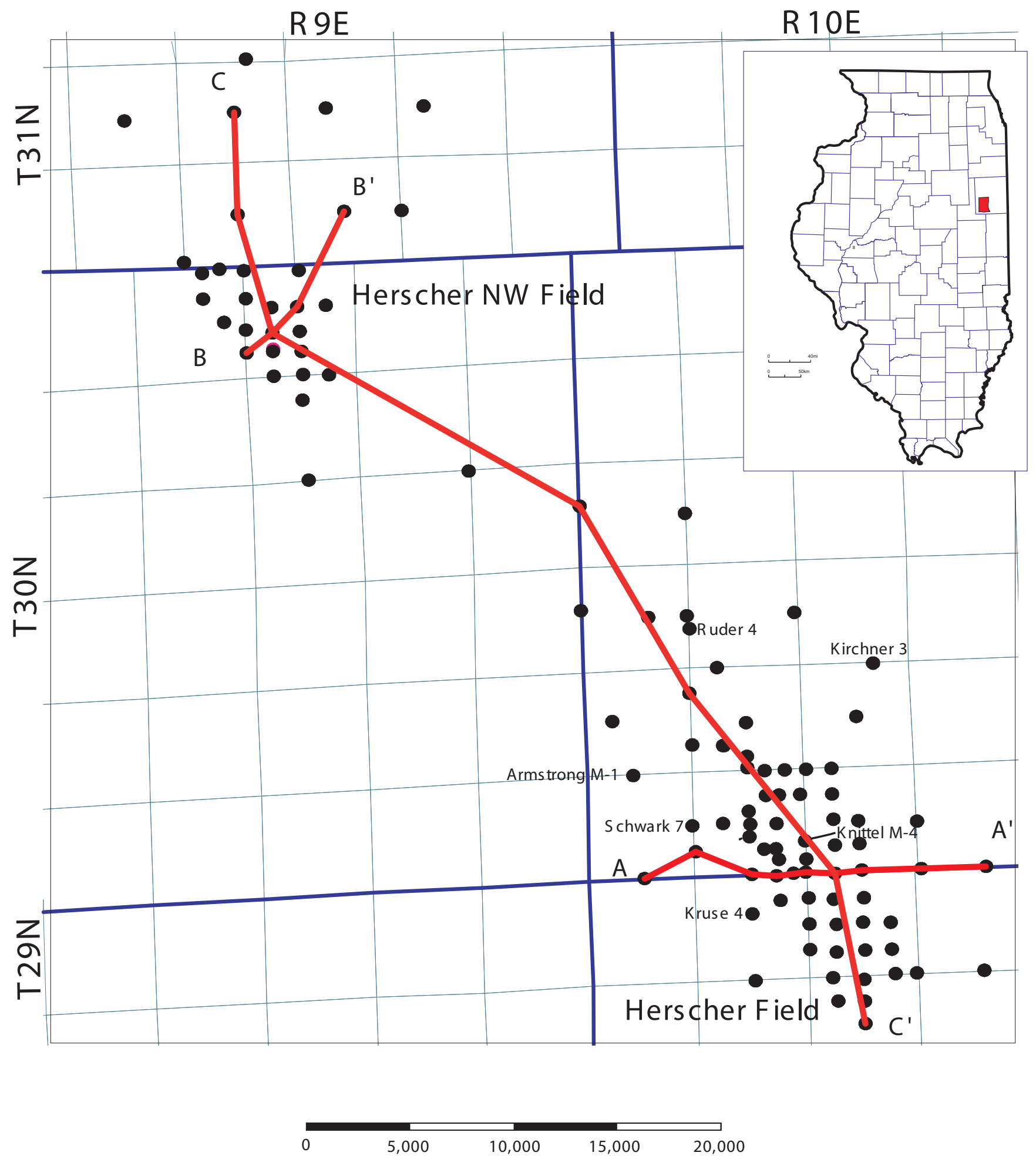

Fig 35 


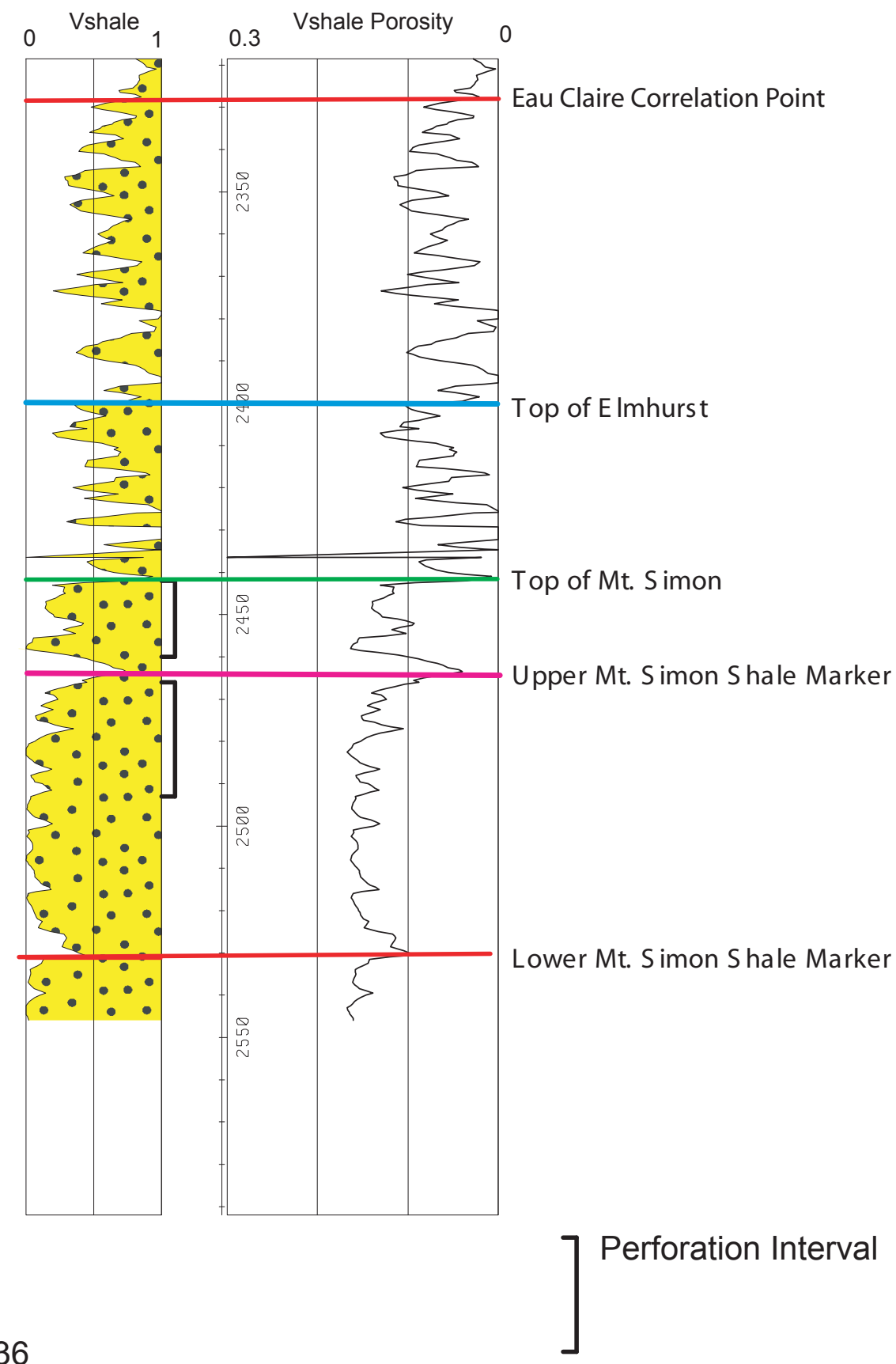

Figure 36 


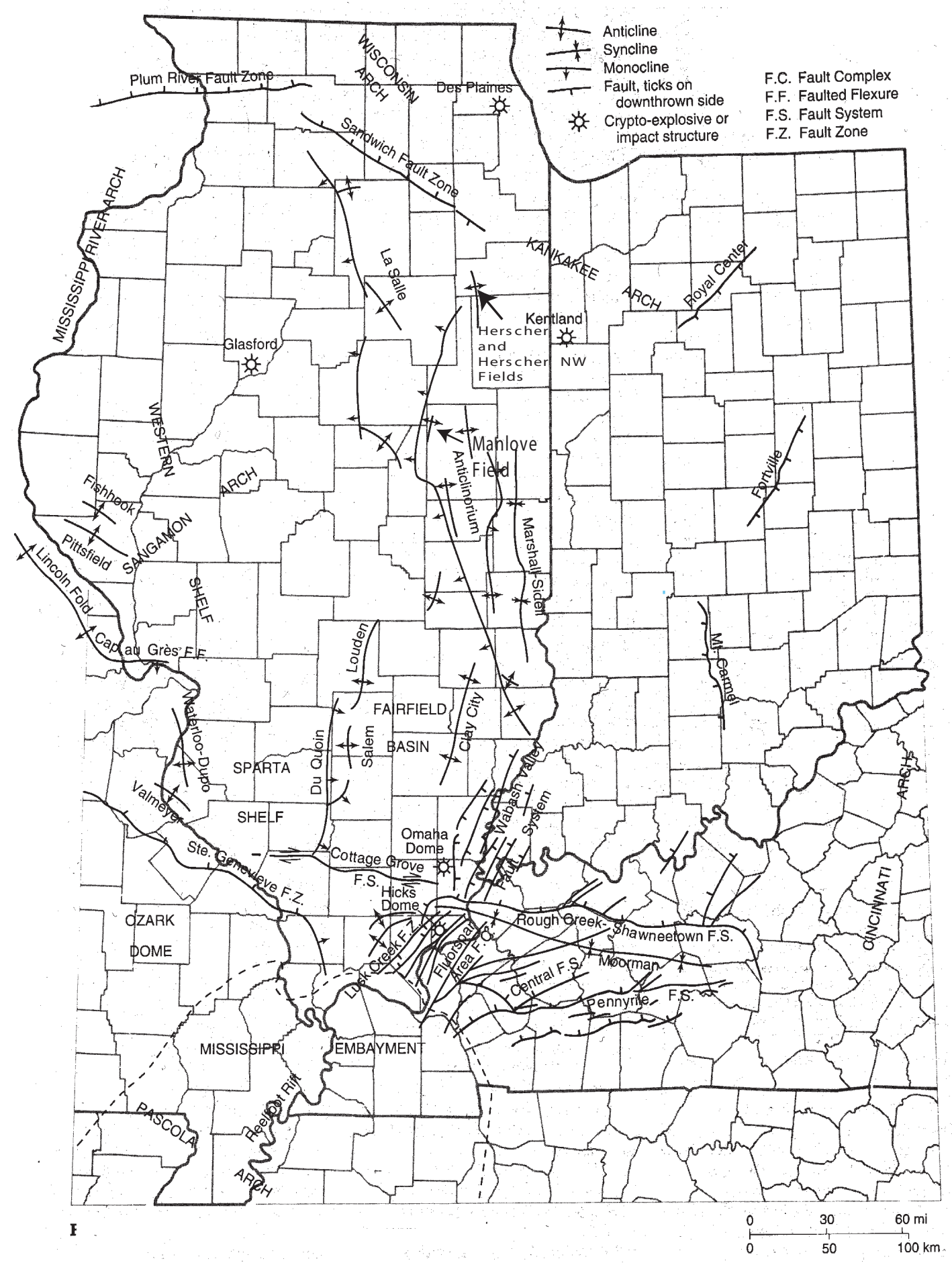

Figure 37 

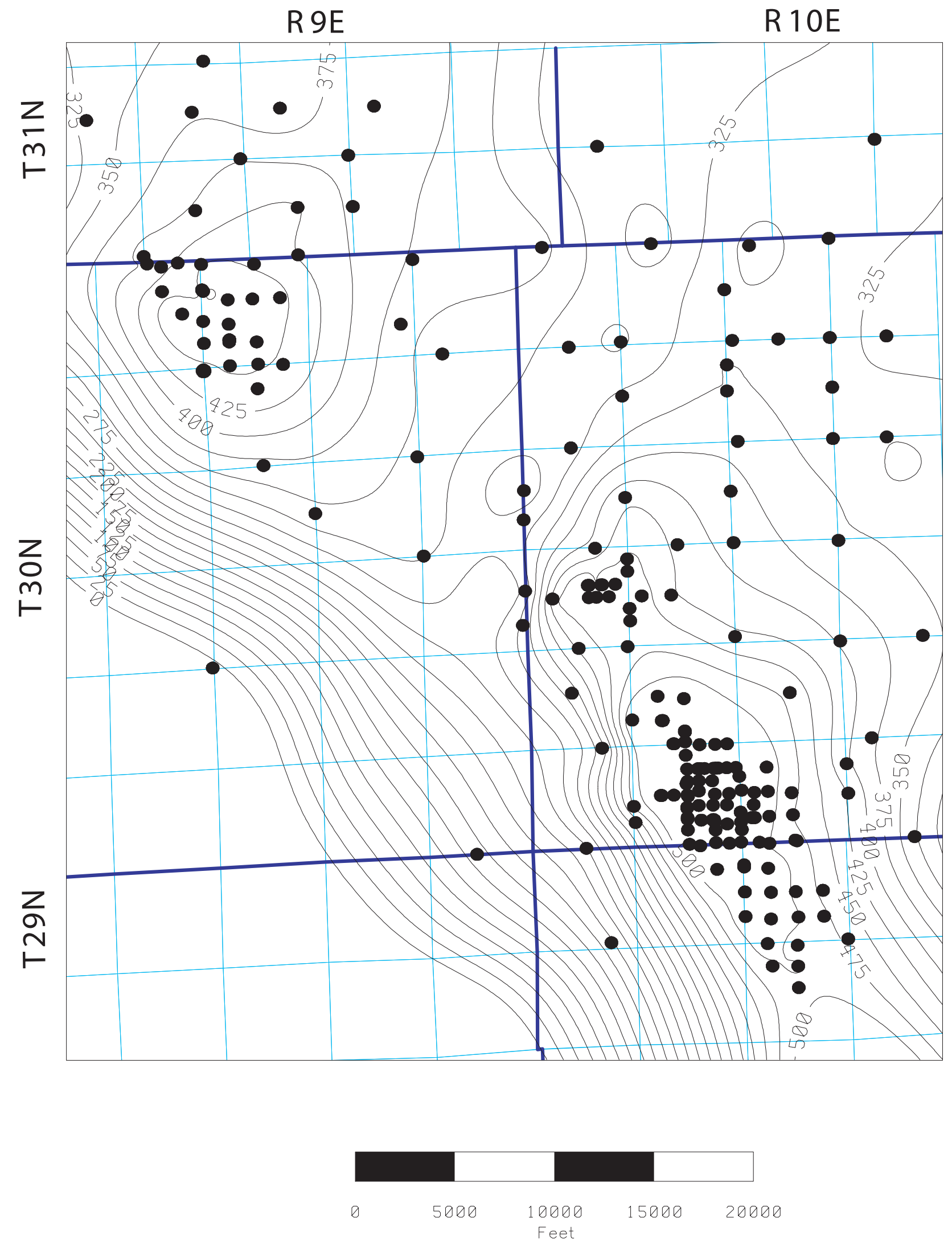

Figure 38 

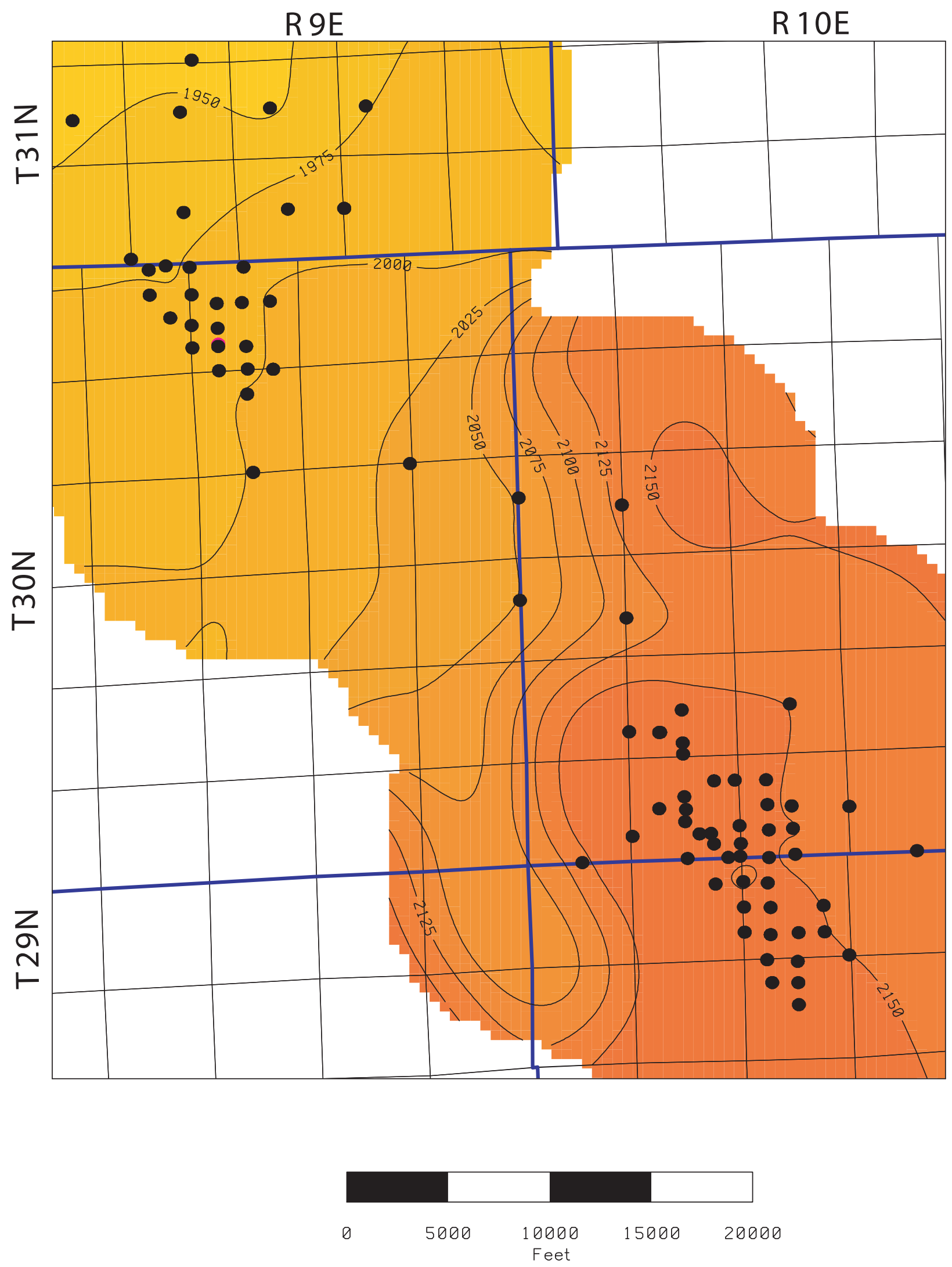

Figure 39 

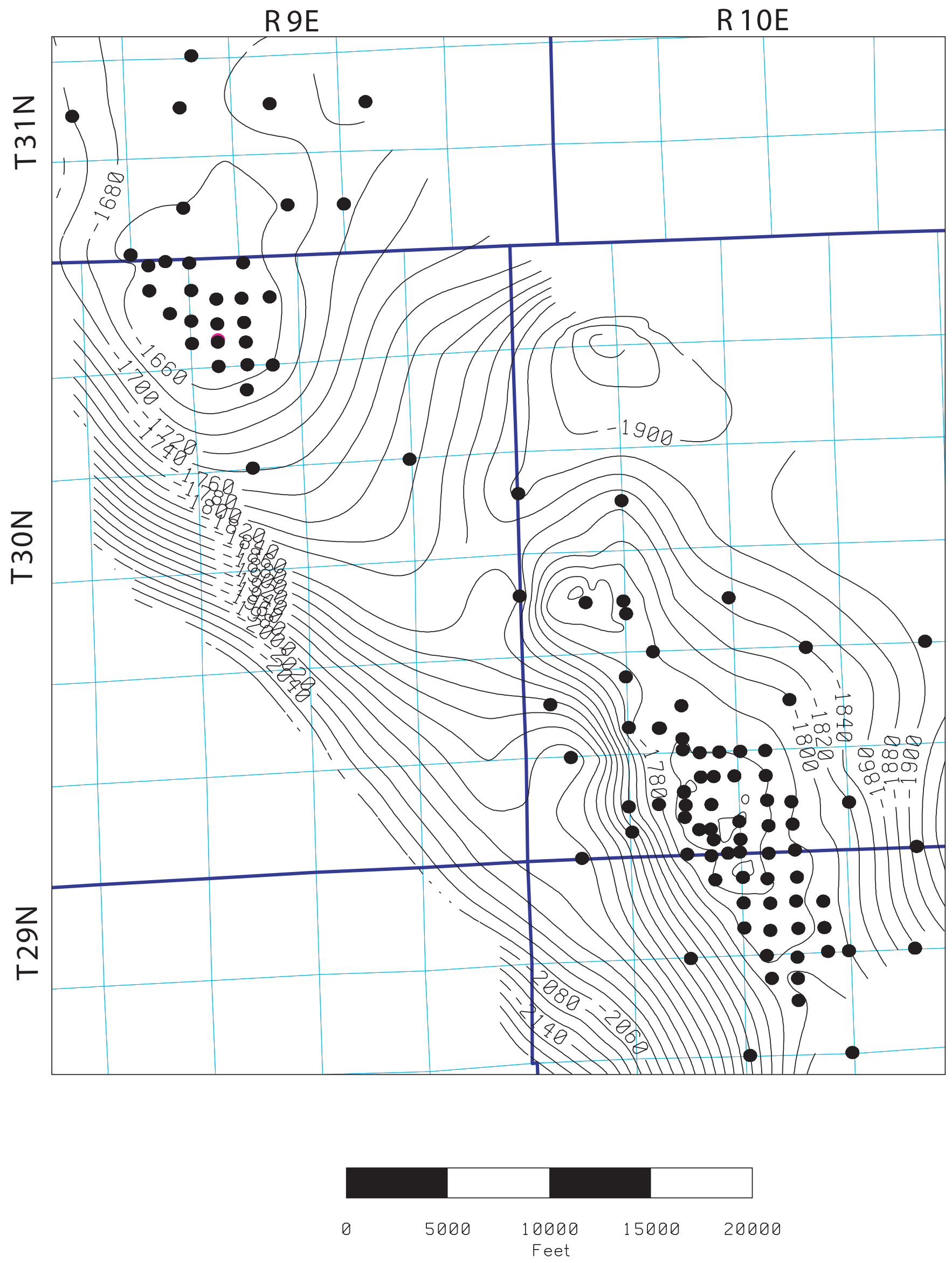

Figure 40 


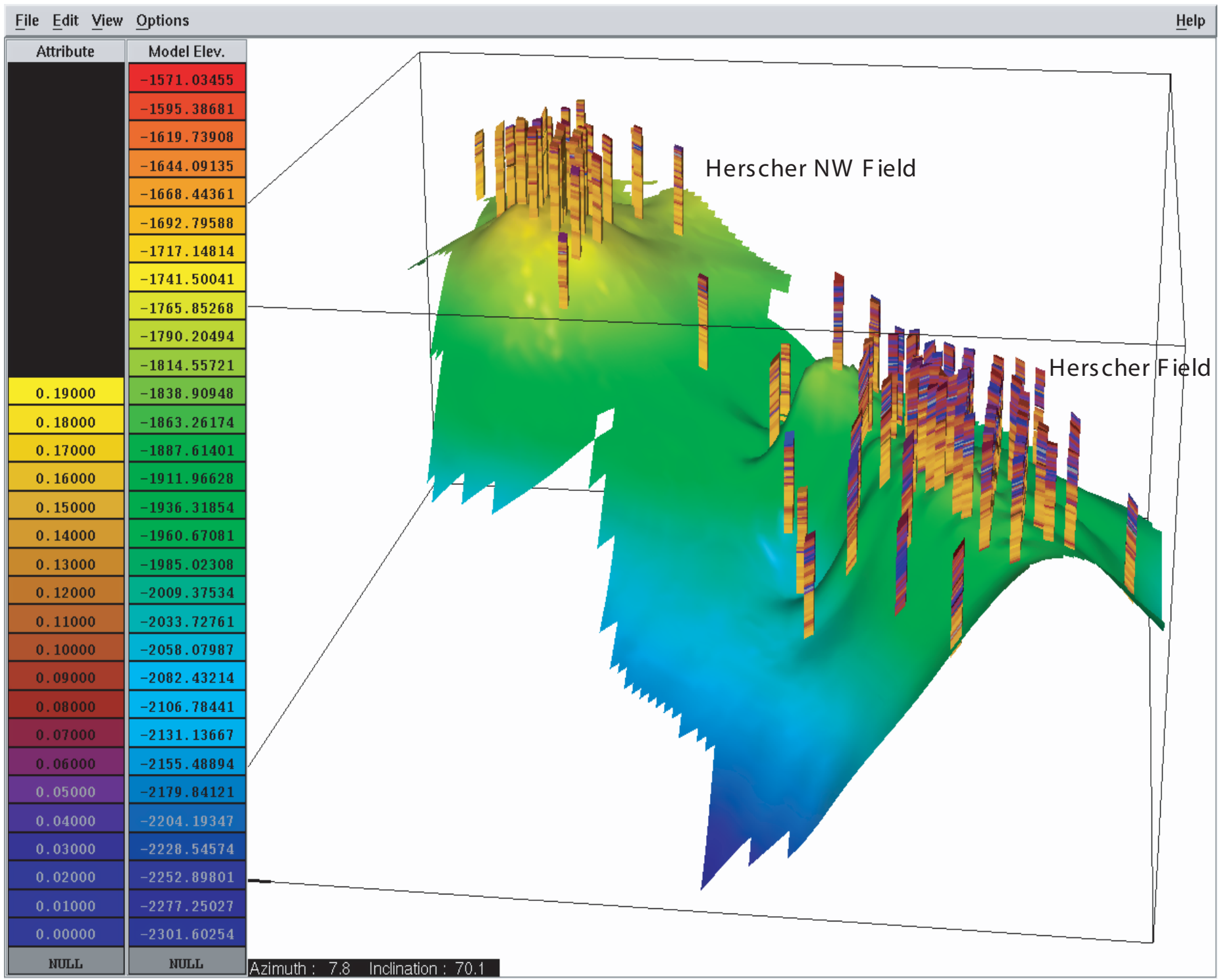

Figure 41 


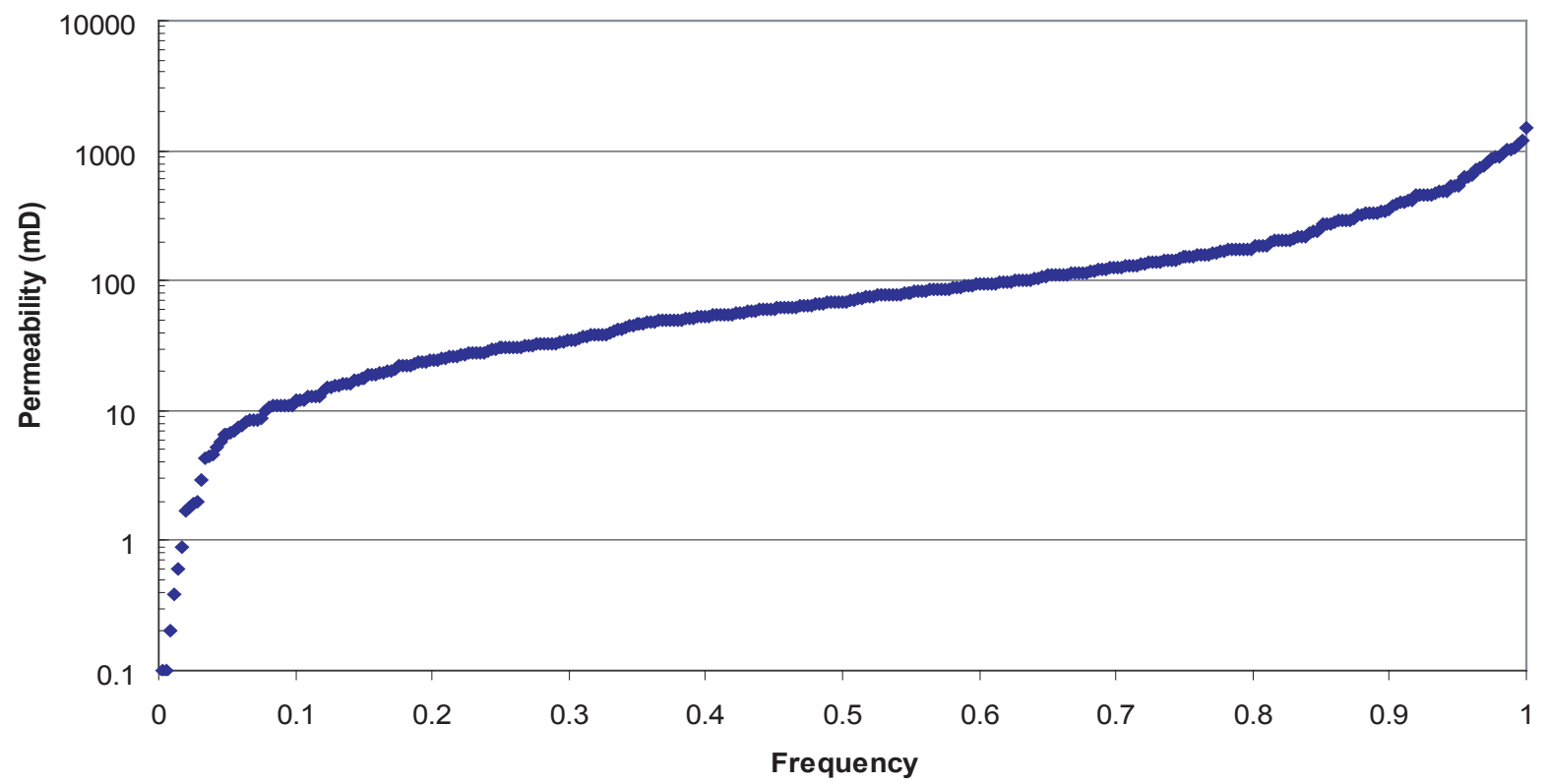

Figure 42 


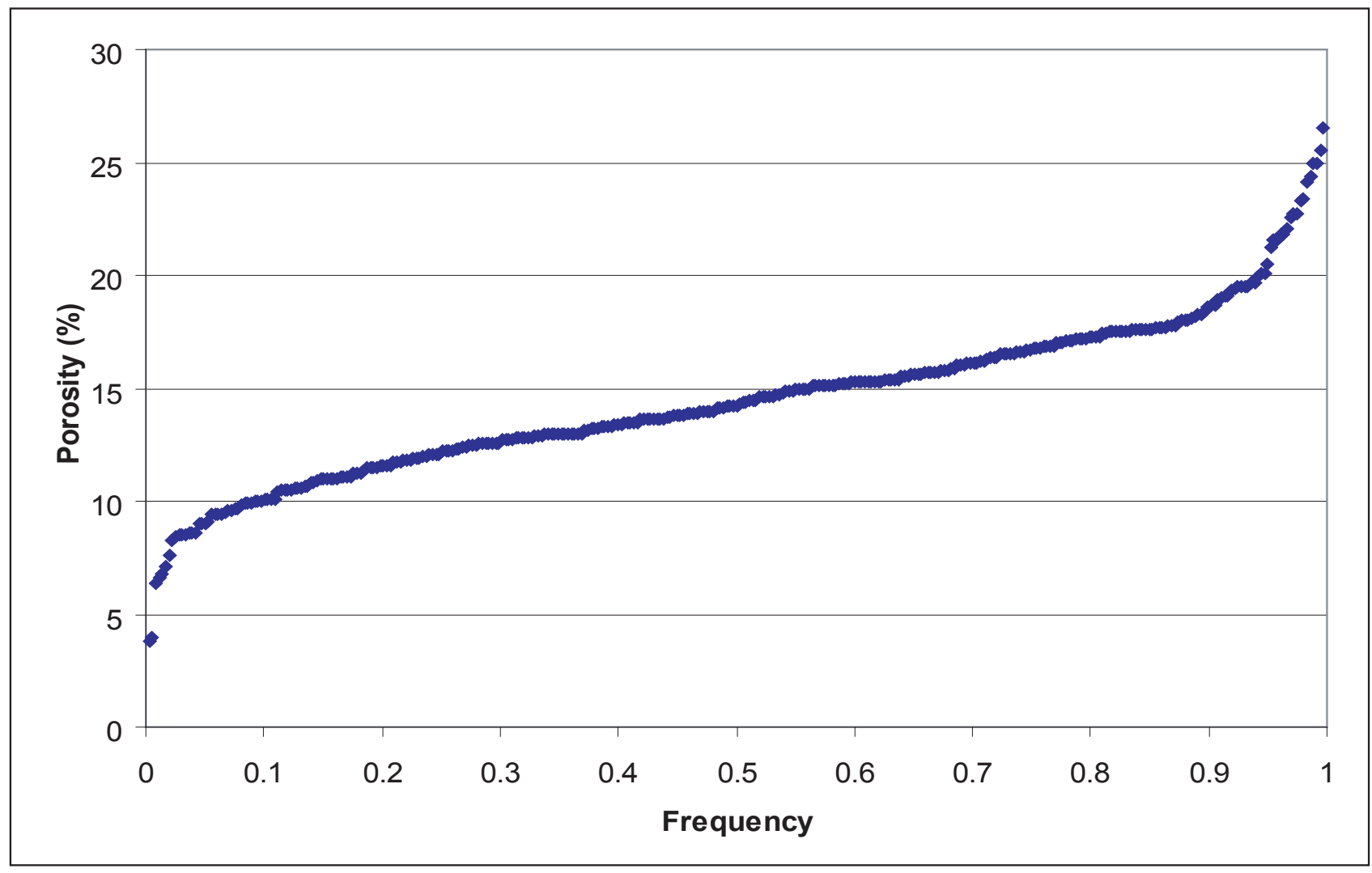

Figure 43 
Ruder 4

vshale porosity

60.0

50.0

40.0

30.0

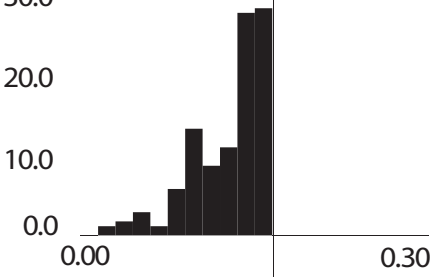

Avg: $0.127 \quad$ Min: 0.017

Med: $0.140 \quad$ Max: 0.163

Ruder 4

neutron porosity

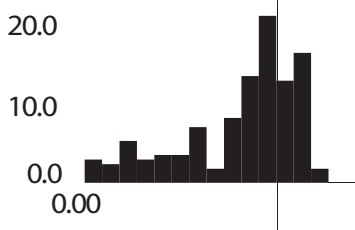

Avg: $0.133 \quad$ Min: 0.005 Med: 0.150 Max: 0.200

Ruder 4

core porosity

50.0

40.0

30.0

20.0

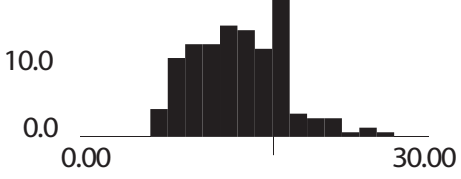

Avg: 13.623

Min: 6.400

Med: 13.588
Kruse 4 vshale porosity

60.0

50.0

40.0

30.0

20.0

0.0

0.00

Avg: 0.137

Med: 0.149

Max: 0.163

Kruse 4 neutron porosity

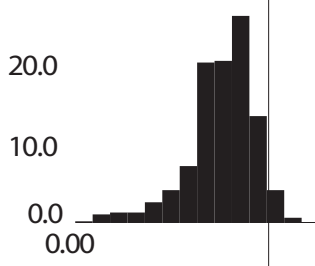

0.30

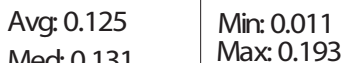

Med: 0.131

Max: 0.193

Kruse 4

core porosity

50.0

40.0

30.0

20.0

10.0

0.0

0.00

Avg: 14.578

Max: 22.100

Min: 9.000

Med: 14.410
Schwark 7

vshale porosity

60.0

50.0

40.0

30.0

20.0

10.0

0.0

0.00

0.30

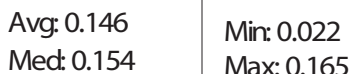

Schwark 7

neutron porosity

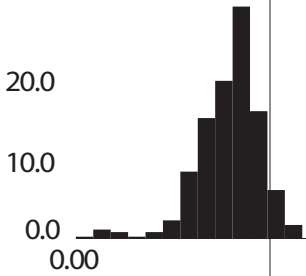

0.30

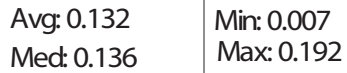

Schwark 7

core porosity

50.0

40.0

30.0

20.0

10.0

0.0

0.00

30.00

Avg: 13.900

Med: 14.125

Figure 44 
a)

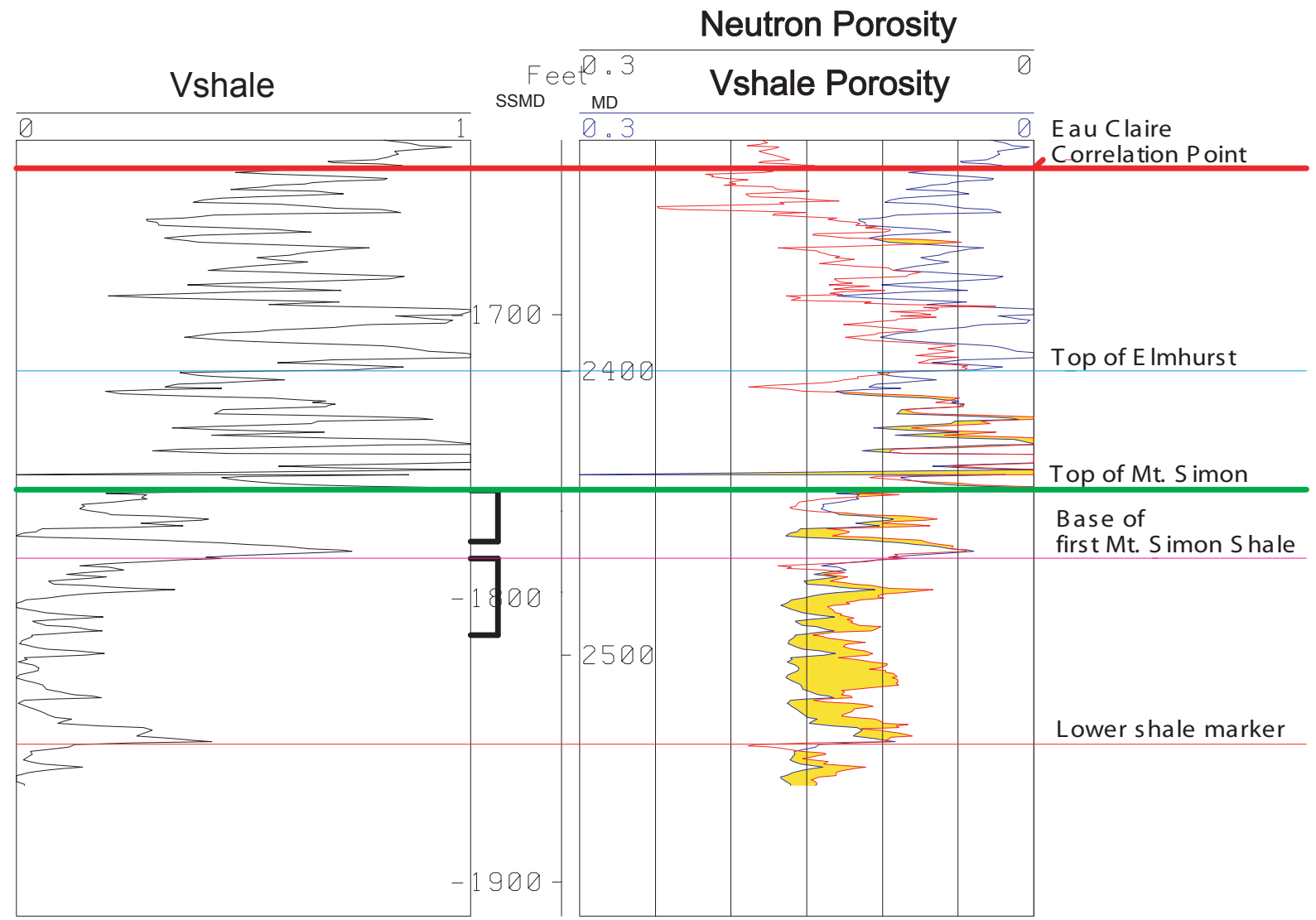

b)

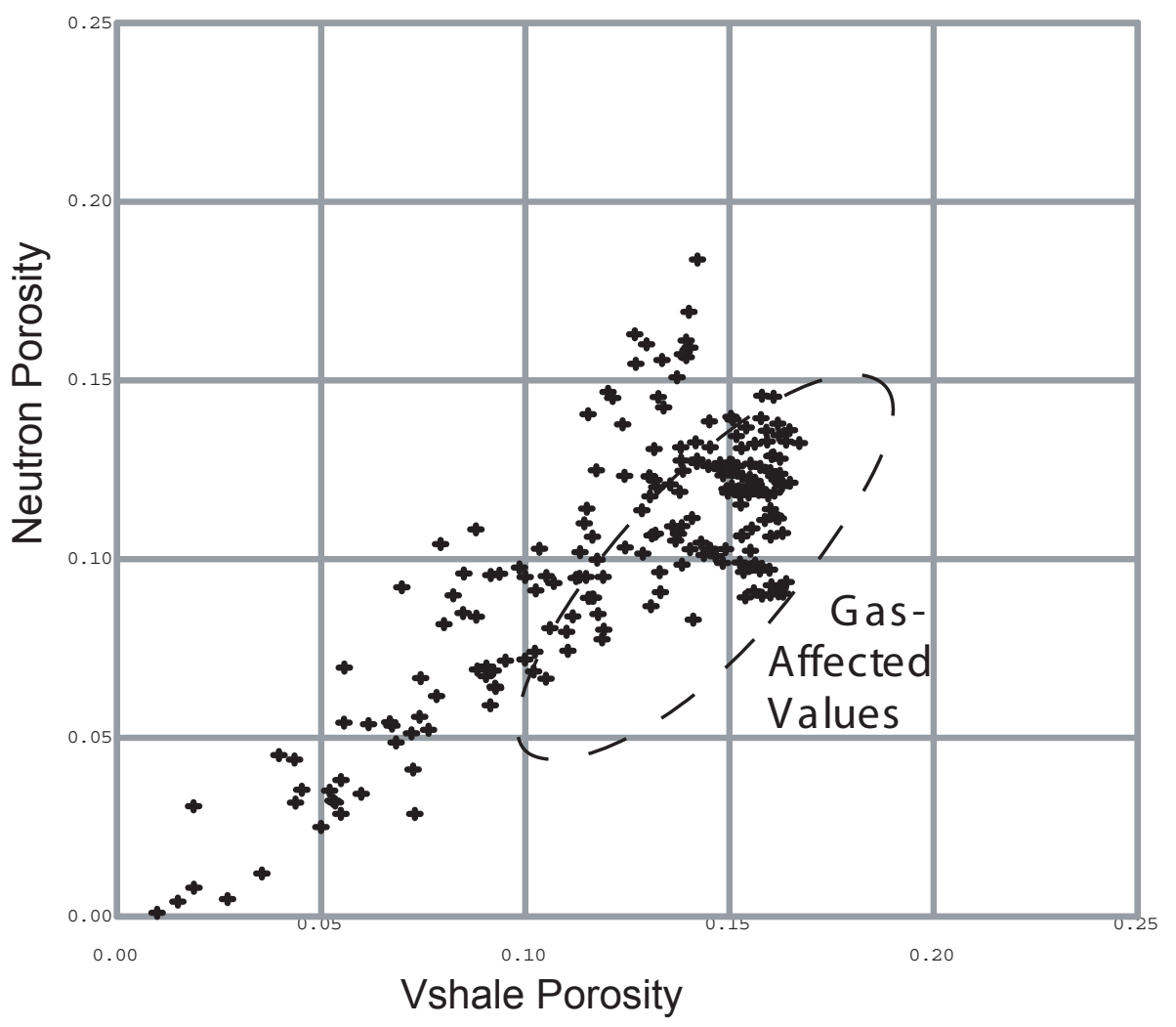

Perforation Interval

Figure 45 
a)

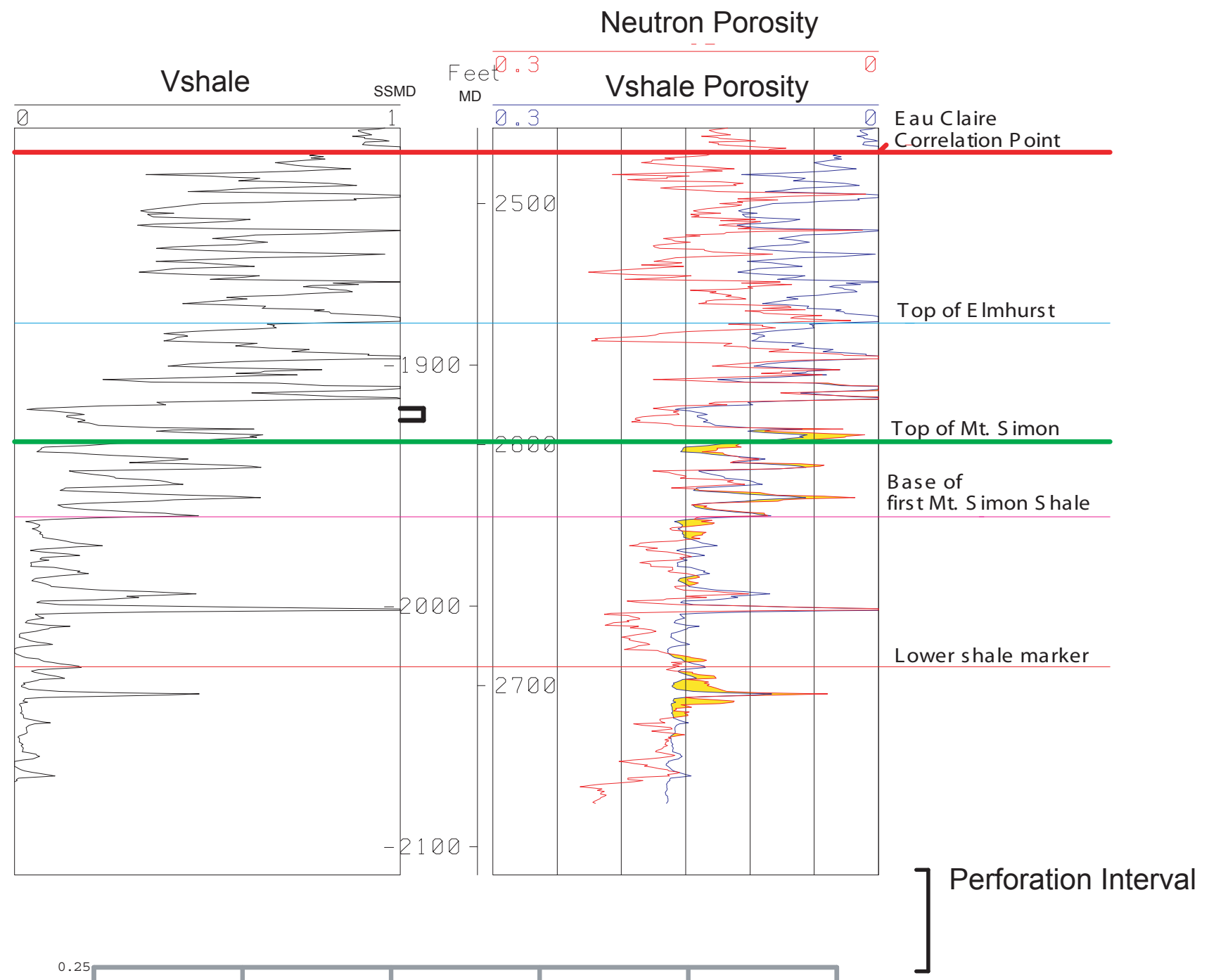

b)

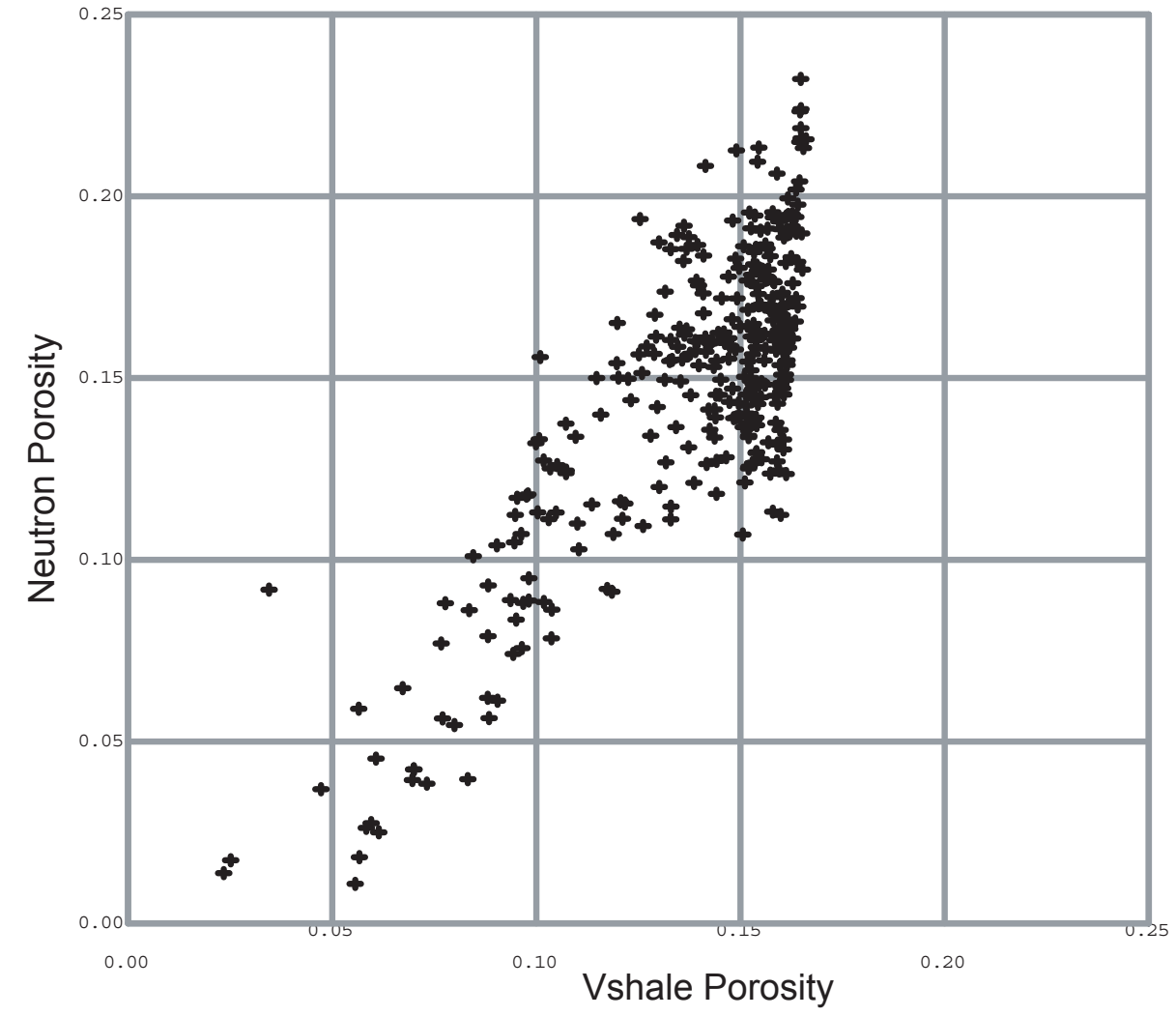

Figure 46 


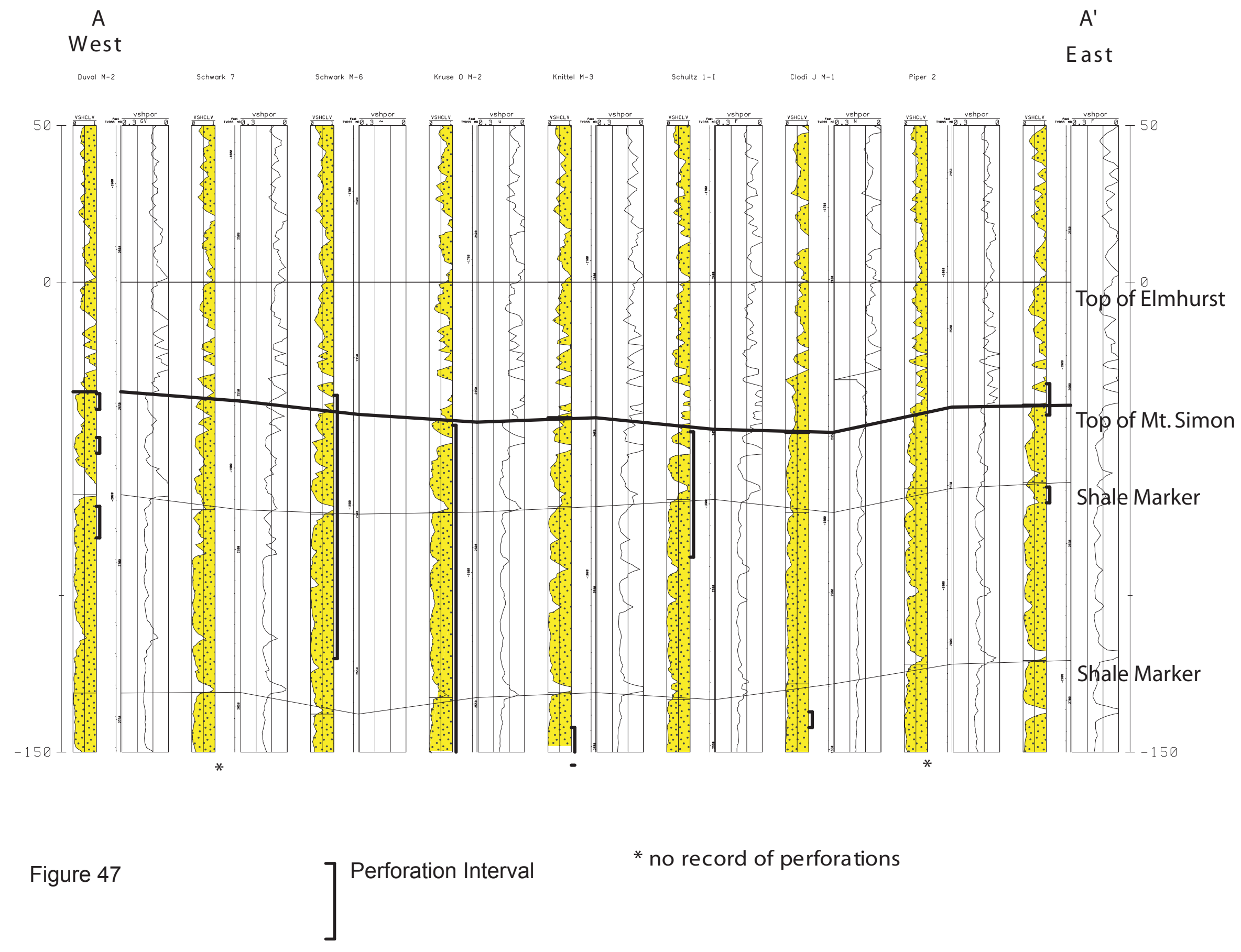


B

West aberlin E 6
Oberlin E 4
B'

Dunn $L 1$ O'Reilly M K 1 East
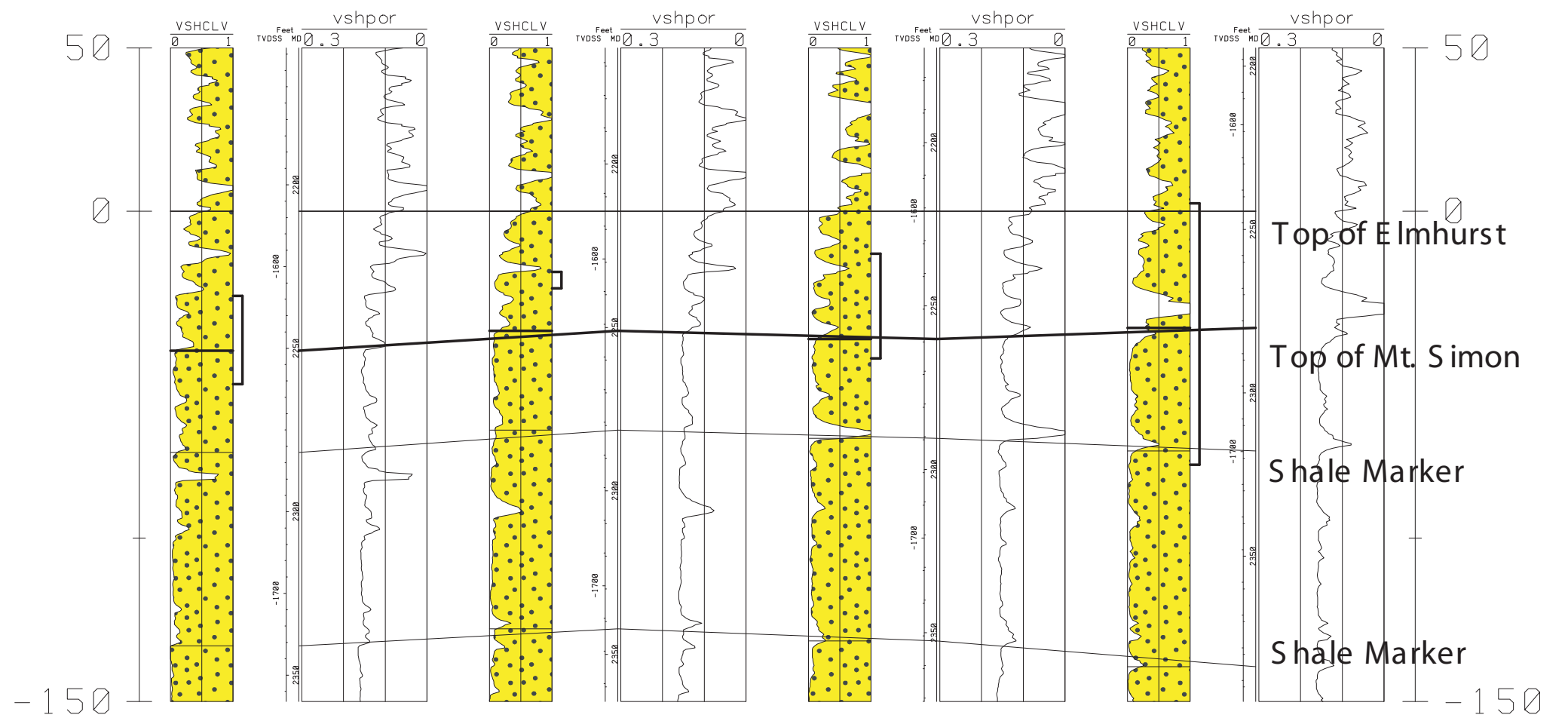

Figure 48

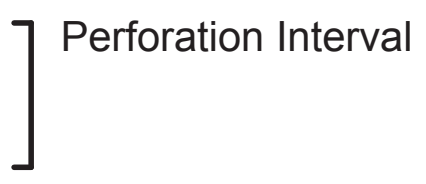


C

Northwest

schultz D 1

Pederson $N J 1$

Appel G M-1

Saffer 3

Schultz $1-1$

Southeast

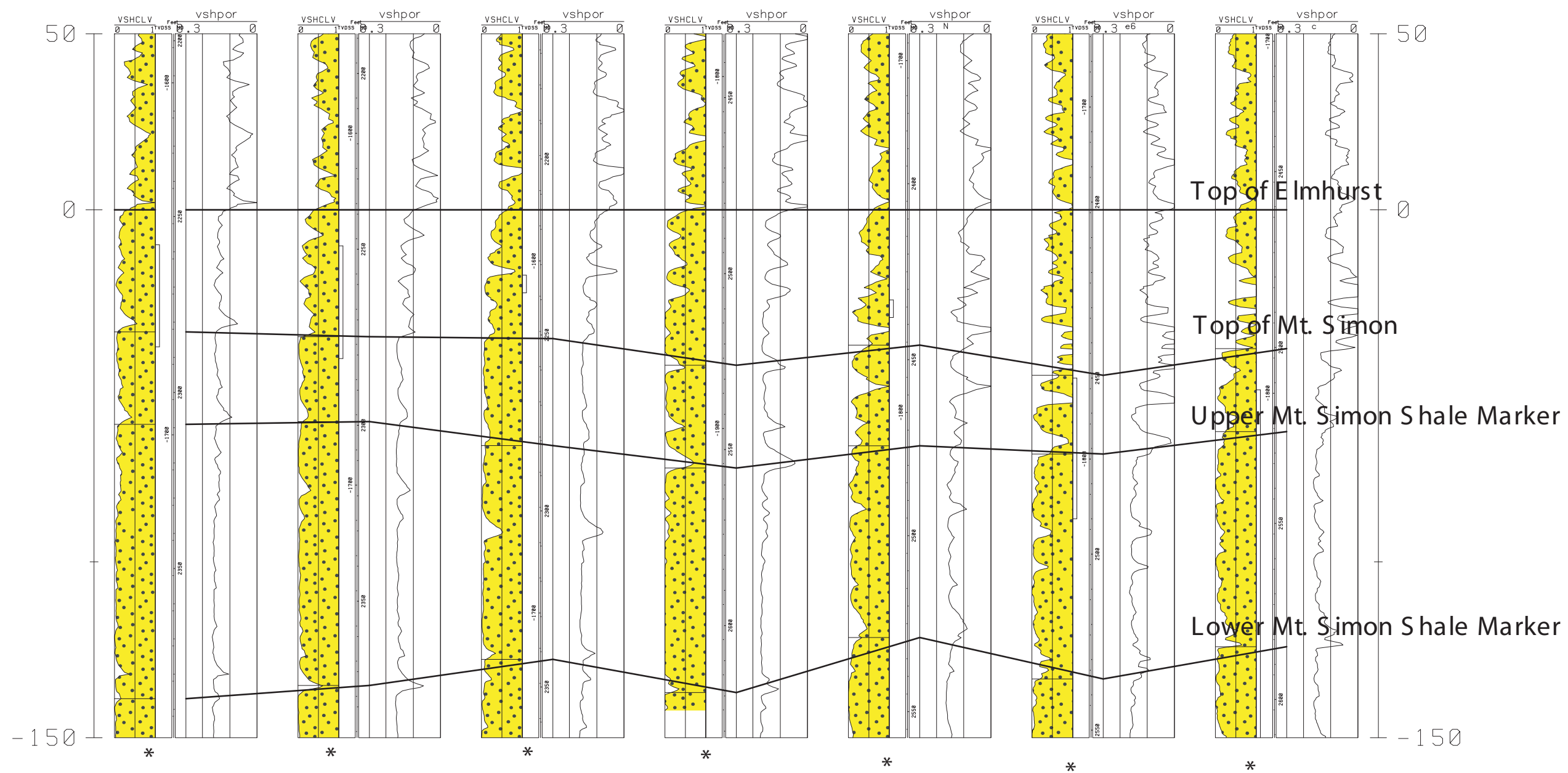

* no record of perforations

Perforation Interval

Figure 49 

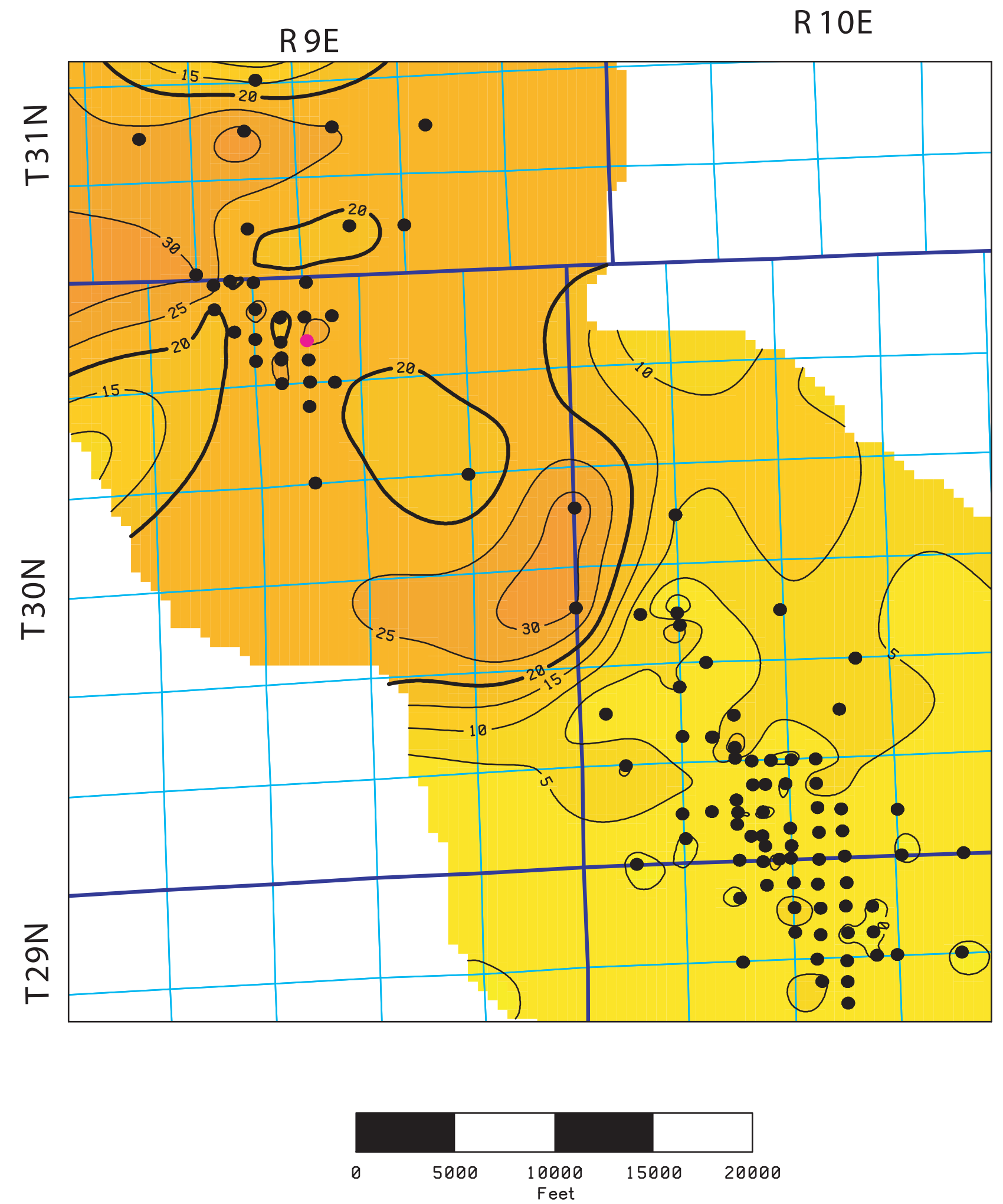

Figure 50 
them 


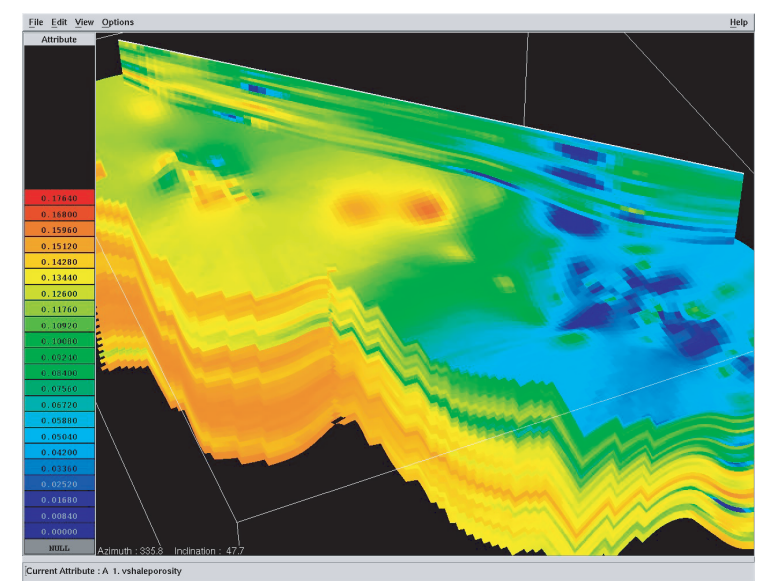

a

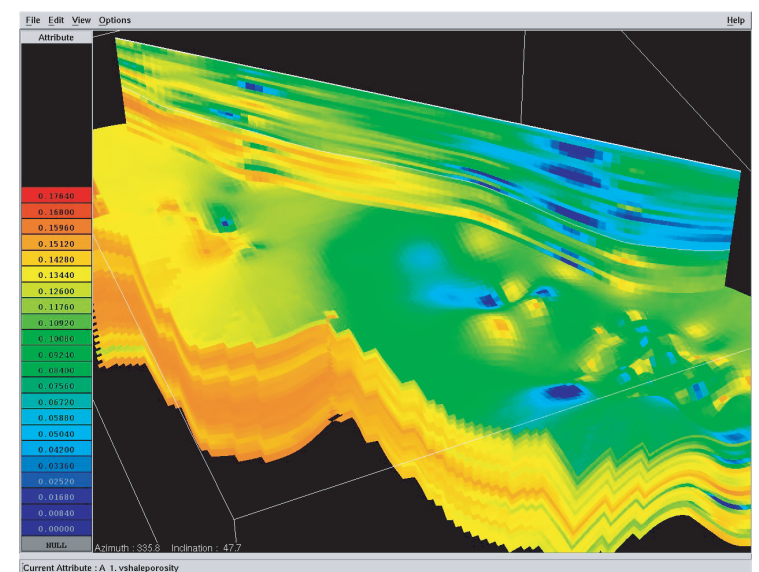

C

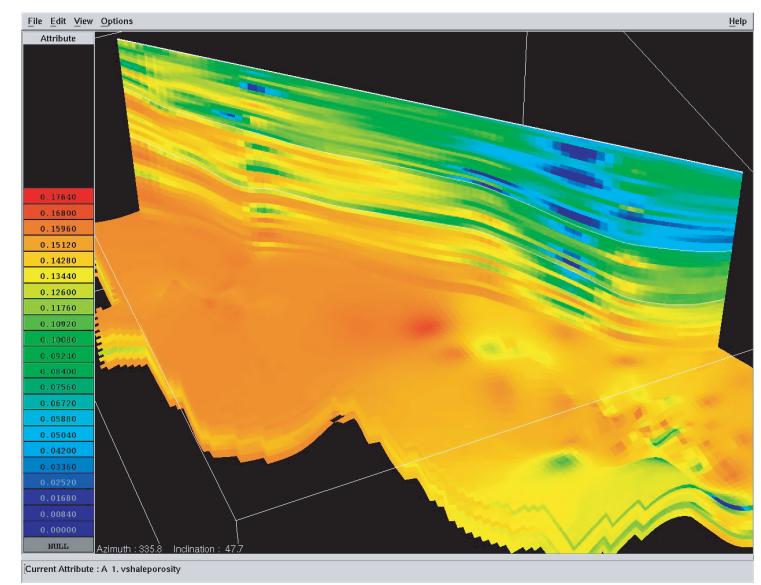

e

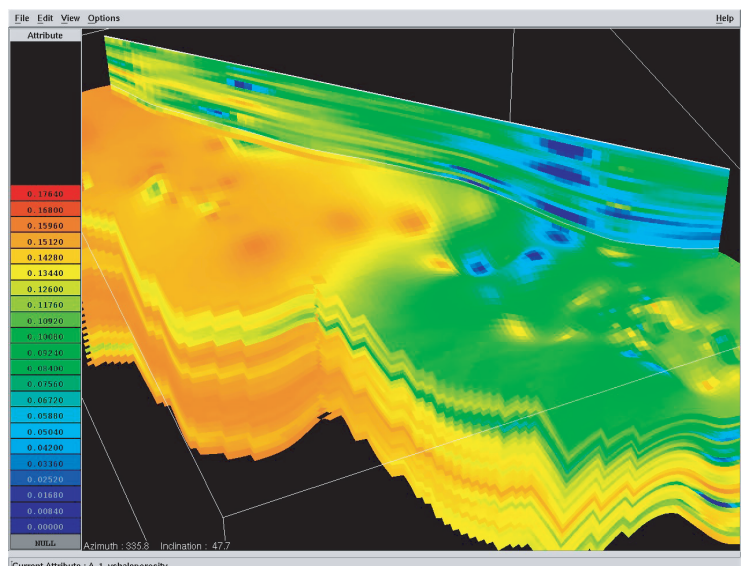

b

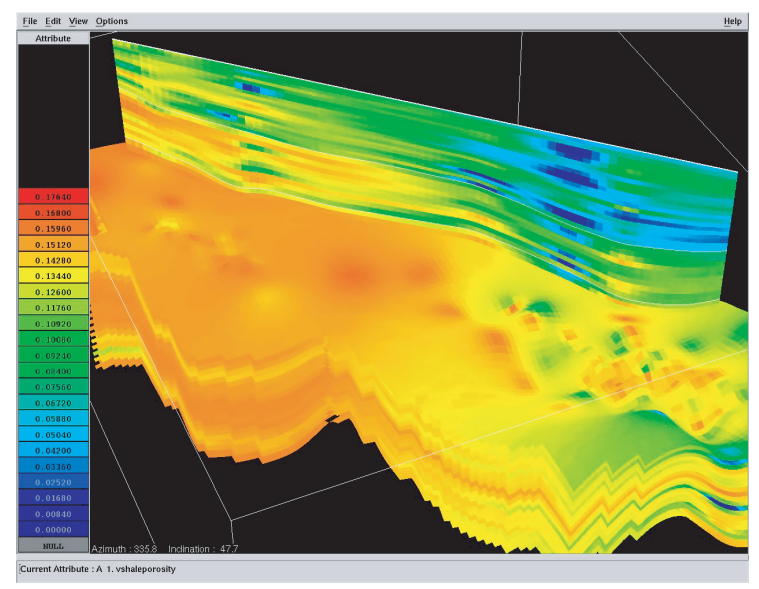

d

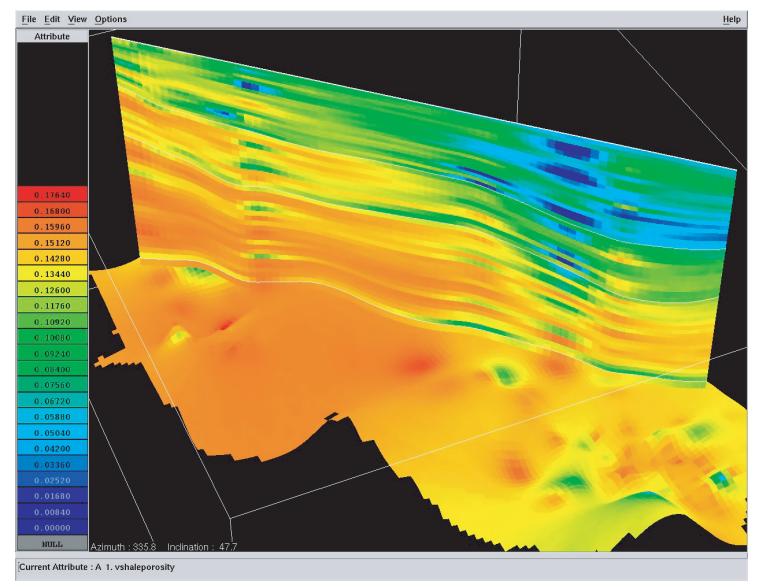

f

Figure 52 